Florida International University FIU Digital Commons

7-12-2012

\title{
Control of MNC's Environmental Performance and the Challenges of Subsidiary Network Dimensions
}

Dina Mahmoud Abdel-Zaher

Florida International University, dzahe001@fiu.edu

DOI: $10.25148 /$ etd.FI12080631

Follow this and additional works at: https://digitalcommons.fiu.edu/etd

\section{Recommended Citation}

Abdel-Zaher, Dina Mahmoud, "Control of MNC's Environmental Performance and the Challenges of Subsidiary Network Dimensions" (2012). FIU Electronic Theses and Dissertations. 673.

https://digitalcommons.fiu.edu/etd/673 


\section{FLORIDA INTERNATIONAL UNIVERSITY}

Miami, Florida

\section{CONTROL OF MNC ENVIRONMENTAL PERFORMANCE AND THE} CHALLENGES OF SUBSIDIARY NETWORK DIMENSIONS

A dissertation submitted in partial fulfillment of

the requirements for the degree of DOCTOR OF PHILOSOPHY

in

BUSINESS ADMINISTRATION

by

Dina Abdel-Zaher

2012 
To: Dean Joyce Elam

College of Business Administration

This dissertation, written by Dina Abdel-Zaher, and entitled Control of MNC's Environmental Performance and the Challenges of Subsidiary Network Dimensions, having been approved in respect to style and intellectual content, is referred to you for judgment.

We have read this dissertation and recommend that it be approved.

Jose de la Torre

Nathan Hiller

William Schneper

Ted London

Walfried Lassar

William Newburry, Major Professor

Date of Defense: July 12, 2012

The dissertation of Dina Abdel-Zaher is approved.

$\begin{array}{r}\text { Dean Joyce Elam } \\ \text { College of Business Administration } \\ \hline \begin{array}{r}\text { Dean Lakshmi N. Reddi } \\ \text { University Graduate School }\end{array}\end{array}$

Florida International University, 2012 


\section{DEDICATION}

I would like to dedicate this work to my honorable father Mahmoud Abdelzaher and mother Amal Hafiz Osman and wonderful husband Khaled Omar, blessed children Fatima and Mariam, incredible family, selfless loving friends, and dedicated mentors. For your support, sincerity, and patience throughout this process, I am forever grateful. It was Almighty God's Mercy and Will followed by your kindness that helped me stay focused on achieving this goal. My father I thank you for your foresight and in being the first to see in me the potential and pushing me hard enough to achieve this goal. My sweet mother I thank you for lending an ear when I needed advise, for being a shoulder to cry on and giving me the hug I needed when I felt overwhelmed. You taught me to always do what your heart tells you is right. And your heart is beautiful. You are my role model. My wonderful husband thank you for providing the love and support before, during and after this journey is completed you are a true blessing and source of joy in my life. My sweet girls thank you for your prayers and patience when you saw me work so hard. My sweet family and friends I thank you for providing the prayers and often the meals and babysitting support to help me stay focused. This degree is truly your achievement allow me to congratulate you all. Finally and most important, all praise and thanks are due to Allah (the Most High The Great) and May God send his Blessings on his Last Messenger, Muhammed, the best of mankind and our teacher in every way. 


\section{ACKNOWLEDGMENTS}

I wish to express my gratitude and highest respect to all the members of my committee Dr. William Newburry, Dr. Jose de la Torre, Dr. Nathan Hiller, Dr. William Schneper, Dr. Ted London and Dr. Walfried Lassar for their continuous support, commitment, and expertise. I would like to express my sincere appreciation to my major professor, Dr. William Newburry for his support and guidance. And a special thanks to Dr. Jose de la Torre and Dr. Walfried Lassar who never hesitated to give their advice and guidance, despite how busy they were, which reflected how much they wanted me to succeed. And of course I cannot express my gratitude to Dr. Paul Miniard who was always there for me to provide the support I needed to complete this journey. It was because of Dr. Miniard's funding in my first term that made pursuing this degree possible. I also like to thank Dr. William Schneper for being the first to recognize my research instinct and contribute to its development. I want to thank him for taking the time to teach and share his advice. And I would also like to thank Dr. Amanda Bullough who reflects the true meaning of "support". I have learned from each one of you. And I want you to know that I appreciate every moment or thought you invested in my development as a scholar and an educator. Finally, I would like to give the utmost thank you to The Creator, who has made our roads cross in this unique journey. It was wonderful working with you all. 


\title{
ABSTRACT OF THE DISSERTATION \\ CONTROL OF MNC ENVIRONMENTAL PERFORMANCE AND THE \\ CHALLENGES OF SUBSIDIARY NETWORK DIMENSIONS
}

by

\author{
Dina Abdel-Zaher \\ Florida International University, 2012 \\ Miami, Florida \\ Professor William Newburry, Major Professor
}

The trend of green consumerism and increased standardization of environmental regulations has driven multinational corporations (MNCs) to seek standardization of environmental practices or at least seek to be associated with such behavior. In fact, many firms are seeking to free ride on this global green movement, without having the actual ecological footprint to substantiate their environmental claims. While scholars have articulated the benefits from such optimization of uniform global green operations, the challenges for MNCs to control and implement such operations are understudied. For firms to translate environmental commitment to actual performance, the obstacles are substantial, particularly for the MNC. This is attributed to headquarters' (HQ) control challenges (1) in managing core elements of the corporate environmental management (CEM) process and specifically matching verbal commitment and policy with ecological performance and by (2) the fact that the MNC operates in multiple markets and the HQ is required to implement policy across complex subsidiary networks consisting of diverse and distant units. Drawing from the literature on HQ challenges of MNC management and control, this study examines (1) how core components of the CEM process impact 
optimization of global environmental performance (GEP) and then uses network theory to examine how (2) a subsidiary network's dimensions can present challenges to the implementation of green management policies. It presents a framework for CEM which includes (1) MNCs' Verbal environmental commitment, (2) green policy ㅌanagement which guides standards for operations, (3) actual environmental Performance reflected in a firm's ecological footprint and (4) corporate environmental Reputation (VMPR). Then it explains how an MNC's key subsidiary network dimensions (density, diversity, and dispersion) create challenges that hinder the relationship between green policy management and actual environmental performance. It combines content analysis, multiple regression, and post-hoc hierarchal cluster analysis to study US manufacturing MNCs. The findings support a positive significant effect of verbal environmental commitment and green policy management on actual global environmental performance and environmental reputation, as well as a direct impact of verbal environmental commitment on green policy management. Unexpectedly, network dimensions were not found to moderate the relationship between green management policy and GEP. 


\section{TABLE OF CONTENTS}

CHAPTER

PAGE

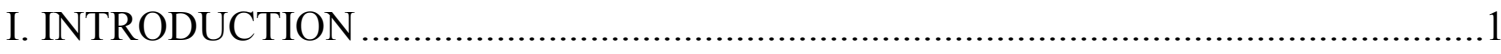

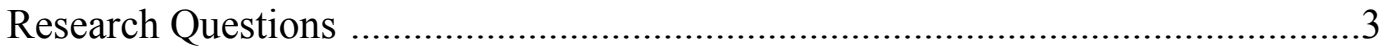

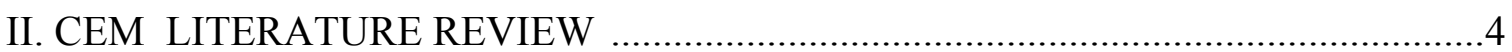

II. RESEARCH QUESTION \#1: MANAGING CORE ELEMENTS OF CEM .........7

Headquarters' Role in CEM: Control Challenges .............................................10

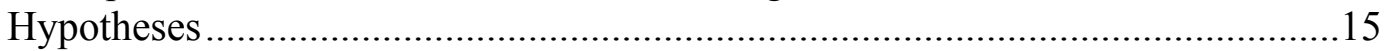

III. RESEARCH QUESTION \#2: CHALLENGES NETWORK DIMENSIONS............27

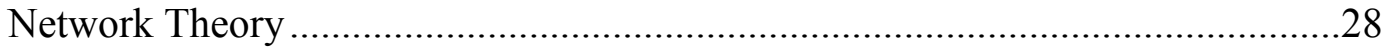

Network Complexity and Environmental Performance..........................................31

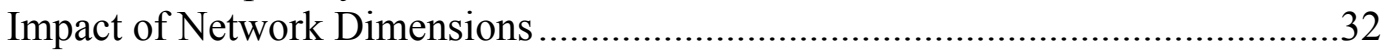

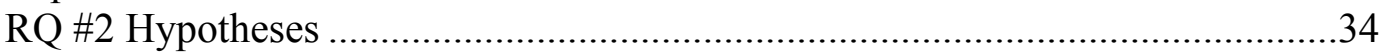

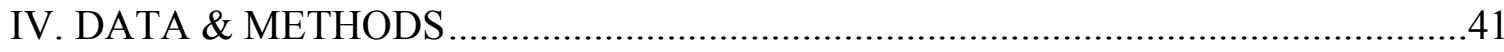

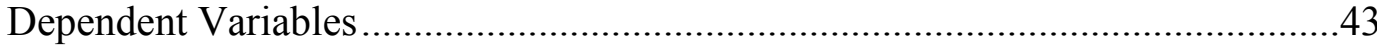

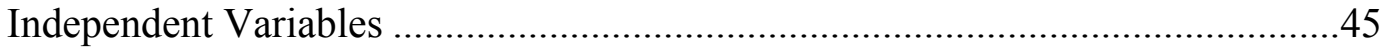

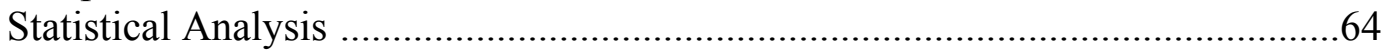

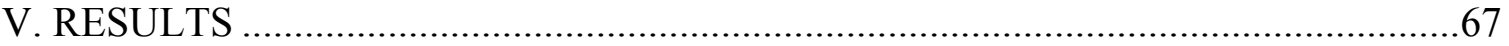

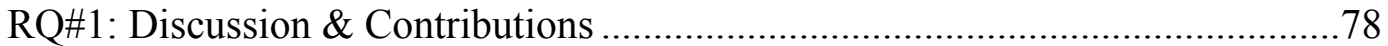

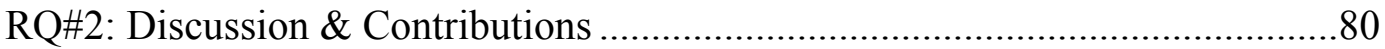

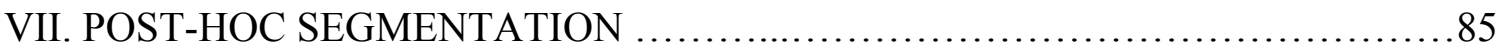

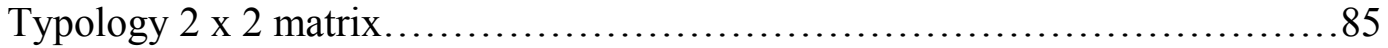

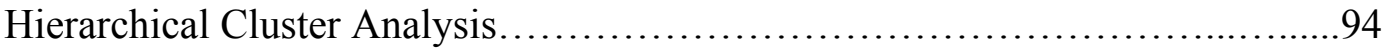

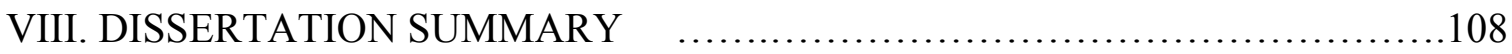

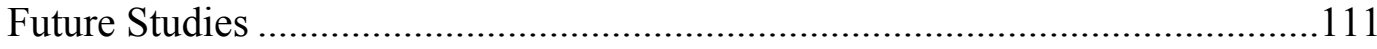

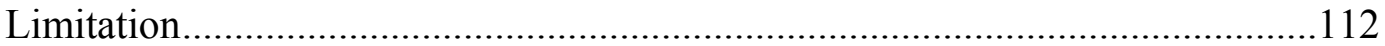

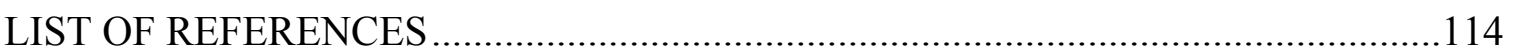

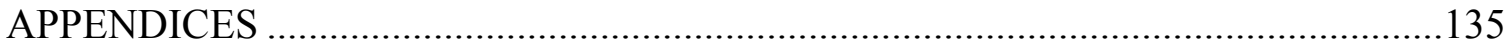

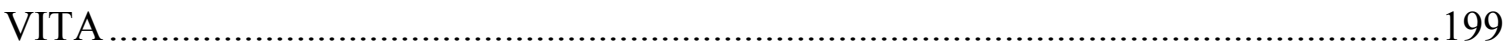




\section{LIST OF TABLES}

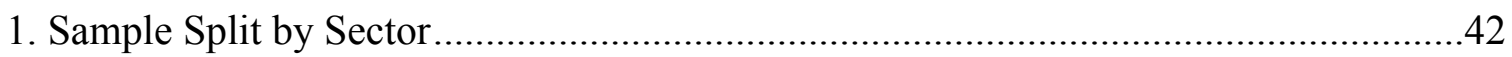

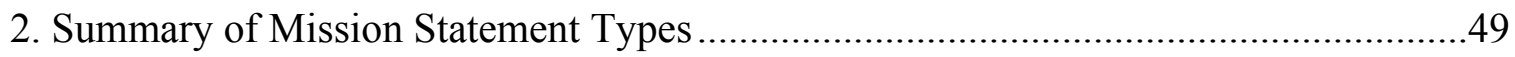

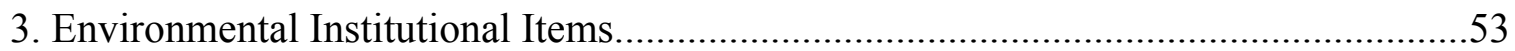

4. Factor Analysis Environmental Institutional Diversity .............................................55

5. Reliability Analysis Institutional Diversity Items.....................................................56

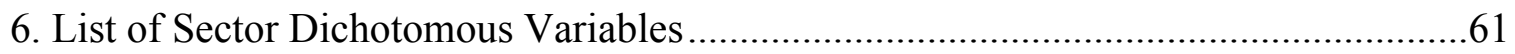

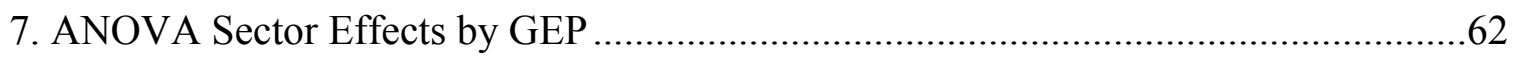

7a. ANOVA Sector Effects by Green Policy …………....................................................62

7b. ANOVA Sector Effects by Reputation ....................................................................64

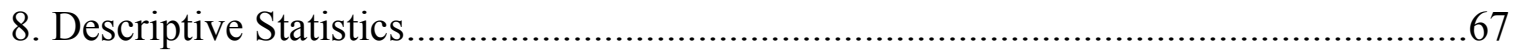

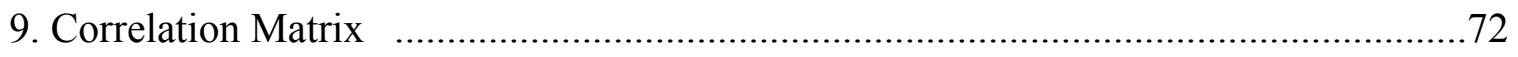

10. Regression Results (Verbal Commitment \& Green Policy Management GEP)..........73

10a. Regression Results (Network Effects) ……………............................................74

11. Regression Results (Green Policy Management) ………...........................................76

12. Regression Results (Environmental Reputation) .......................................................77

13. Cross tabulations (GEP \& Environmental Institutional Network Score) .....................89

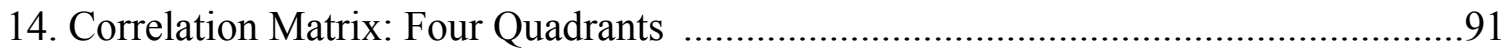

15. Post Hoc Regressions: Four Quadrants to Predict GEP............................................92

16. Post Hoc Regressions: Four Quadrants to Predict Network Density............................93

17. Hierarchical cluster analysis Descriptive Statistics: 6 clusters ...................................94

18. Hierarchical cluster analysis One Sample Test: 6 clusters .....................................95

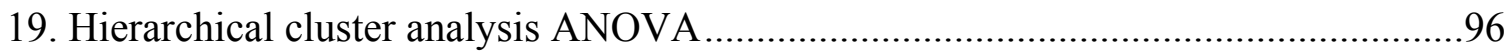


20a. Duncan Test: Green Policies Management

20b. Duncan Test: GEP

20c. Duncan Test: Density

20d. Duncan Test: Geographic distance KM

.100

20e. Duncan Test: Environmental institutional network score ....................................101

21. Summary of Hierarchical Cluster Classification 


\section{LIST OF FIGURES}

FIGURE

PAGE

1. Framework for Corporate Environmental Management (VMPR) .............................14

2. Corporate Environmental Management and Strategy Formulation ............................26

3. Corporate Environmental Management Control......................................................... 32

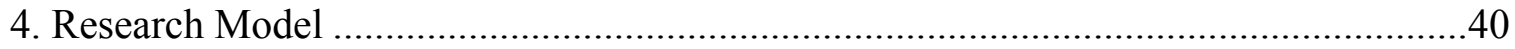

5. Environmental Reputation Frequency Distribution ...............................................45

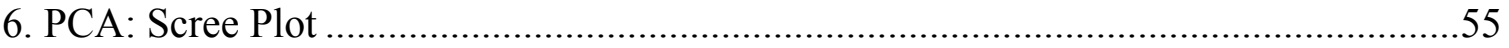

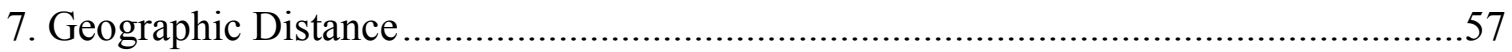

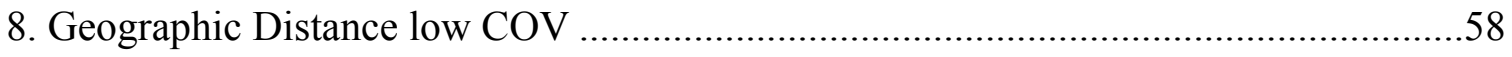

9. Geographic Distance low COV/High Geographic Distance......................................59

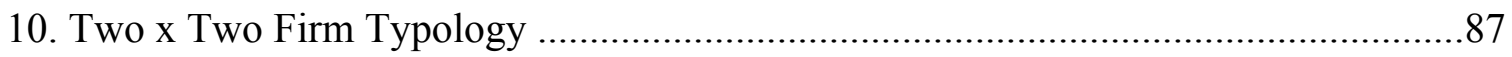




\section{ACRONYMS AND ABBREVIATIONS}

$\begin{array}{ll}\text { MNC } & \text { Multinational Corporations } \\ \text { GEP } & \text { Global Environmental Performance } \\ \text { VMPR } & \text { Verbal Commitment, Management, Performance, Reputation } \\ \text { CSR } & \text { Corporate social responsibility } \\ \text { HQ } & \text { Headquarters } \\ \text { FDI } & \text { Foreign Direct Investment } \\ \text { NGOs } & \text { Non governmental Organizations } \\ \text { CEM } & \text { Corporate Environmental Management } \\ \text { PCA } & \text { Principle Component Analysis } \\ \text { EFA } & \text { Exploratory Factor Analysis } \\ \text { RQ } & \text { Research Question } \\ \text { DV } & \text { Dependent Variable } \\ \text { PSI } & \text { Pacific Sustainability Index }\end{array}$




\section{INTRODUCTION}

MNCs dominate the majority of high pollution producing industries like chemical, petroleum, and heavy manufacturing, and being environmentally responsible has become an imperative component of operating within today's global marketplace (Kolk, 2005). Despite the significant literature examining why environmental compliance, self regulation, and standardization are advantageous (Hart, 1995; Dowell et al., 2000; Carnicross, 1992; Porter, 1990; Christmann, 2004), the challenges of achieving global environmental performance (GEP) are less discussed (Aguilera-Caracuel, Aragón-Correa, \& Hurtado-Torres, 2011). The increased trend of global environmental regulations and green consumerism movements have shifted the scholarly debate from focusing on firms who are seeking to exploit lax environmental contexts (Birdsall \& Wheeler, 1992) to those who are moving beyond mere compliance towards building green competitive advantages and sustainability (Christmann, 2004; King \& Shaver, 2001) for whom this study seeks to provide useful insights. In addition, large variations in environmental performance among firms from the same home market, industry, and environmental regulatory contexts (Dasgupta, Hettige \& Wheeler, 2000) direct the research question to look beyond external market regulations as the sole driver of global environmental performance (GEP) and in doing so attempt to better understand the possible challenges preventing MNCs from achieving global environmental performance (Mohan, 2006), focusing on the expected headquarters (HQ) role to control and/or monitor global environmental performance of its global operations. 
Corporate social responsibility (CSR) is defined as the "business organization's responsibility for integrating stakeholder concerns in routine business activities for primary stakeholders", whereby the environment is regarded as a primary stakeholder (Mohan 2006: 10; Starik, 1995). Corporate environmental management (CEM) refers to "corporate environmental responsibilities, practices, procedures and the processes for determining and implementing corporate environmental policy" (Netherwood, 1996: 35).

In order to examine the challenges MNCs may face in optimizing global environmental performance, the objective of this research is to (1) analyze core elements of the corporate environmental management process differentiating between verbal commitment to act, actual ecological footprint of the $\mathrm{MNC}$ as a whole and its environmental reputation. Using this comprehensive approach, this study draws from the headquarters control literature to examine the impact of HQ verbal environmental commitment (what they say they will do) and environmental policies (what they set out to do) on actual environmental performance (GEP) (what subsidiaries actually do) and environmental reputation (what the firm becomes perceived as doing by others).

Furthermore, the second objective of this study is to (2) examine the moderating impact of MNC subsidiary network dimensions on the relationship between green policies and actual environmental performance, a moderating relationship which has received lesser theoretical attention. It is the subsidiary network that facilitates adoption of common practices as well as headquarters control and management of the subsidiary network. The 
degree to which MNCs can effectively use their internal networks to implement strategies is often a function of limitations inherent within their inter-organizational structures (Galbraith \& Kazanjian, 1986; Ghoshal \& Bartlett, 1990; Stopford \& Wells, 1972).

This study takes a comprehensive approach to examining CEM by first drawing from the literature on the HQ role in management/control of the MNC to (1) examine the core components of the CEM process which includes Verbal environmental commitment, environmental Management standards/policy, actual global environmental Performance, and finally corporate environmental Reputation (VMPR framework). Second, it uses network theory to (2) examine how key network dimensions can challenge the implementation of CEM and hinder MNC GEP, specifically focusing on the relationship between green policy management and actual practice.

\section{Research Questions}

This study has two main research question: (RQ \#1) How do the core elements of the CEM process work together to impact global environmental performance, distinguishing between HQ control efforts through the use of verbal commitment vs. formalization of environmental management policies on ecological performance? In doing so, the dissertation attempts to identify firms who are free riding (green washing) on this green

movement without reflecting this commitment to actual ecological performance. And then, (RQ \#2) how do inherent complexities of subsidiary network design present challenges to global environmental performance? In doing so, the study seeks to provide 
a better understanding of the challenges faced by MNCs who are in pursuit of optimizing GEP within their complex networks. The dissertation aims to contribute specifically to the MNC CEM process and global implementation literatures, highlighting the difficulties faced by headquarters in managing the core elements of the CEM process and in driving uniform best practices across subsidiaries.

\section{CEM Literature Review}

While significant literature exists on the reasons or expected gains from firms behaving responsibly towards the environment, this study focuses on the challenges these firms face in accomplishing this, which are less understood, particularly when incorporating the international nature of the MNC (Mohan, 2006). The study attempts to provide key insights on how and why an MNC's global CSR commitment is not to be regarded as an easy headquarters top down decision (Barin-Cruz \& Pedrozo, 2009).

Within the context of environmental performance, researchers have argued for the importance of streamlining and uniformity of environmental practices, which is likely to increase global competitiveness (Christmann, 1998; 2004). Aragon-Correa and Sharma (2003: 85) argued that "organizations that adopt a consistently proactive approach will develop a dynamic ability through which they will reap rewards during periods of state uncertainty and complexity in the general business environment by reducing organization and effect uncertainty at the business-natural environment interface". Firms' self regulation practices often occur through the deployment of a single global environmental 
policy across their multiple subsidiaries (Christmann, 2004). "By specifying a single corporate standard, performance monitoring and evaluation costs might be reduced because a single set of values, specifications, and procedures can be deployed throughout the world, without the need to consider local deviations from the norm" (Dowell, et al., 2000: 1062). Uniform environmental policy will make it easier for a HQ to manage and coordinate operations, which includes the adoption of new technology and reduces complexities of operation (Christmann, 2004). These are the same motivations commonly noted for standardizing other key functions (Christmann, 2004). Dowell and colleagues' (2000) investigation confirms that MNCs that apply a "single stringent global environmental standard" actually have higher market values, as measured by Tobin's q. For a literature review on the relationship between firm performance and environmental behaviors, see Molina-Azorín and colleagues (2009), who provide evidence of more studies finding a positive relationship between firm performance and environmental behaviors, although conclusive evidence is still mixed.

However, given the complexity of managing the MNC, it is unlikely that uniform adoption of environmental polices is likely to be achieved smoothly via headquarters top down decisions (Tsai \& Child, 1997). Newton and Harte (1997) critique business literature that assumes the adoption of green policies will occur in an "ordered conversion" fashion. They explain that thinking firms can smoothly adopt management practices to comply with increased environmental regulations is "unrealistic" (Rugman \& Verbeke, 1998: 364). This study seeks to break down these challenges by first (1) examining how $\mathrm{HQ}$ attempts to control MNC environmental behavior via the use of firm 
verbal commitment and formalized policy impact environmental performance and then (2) how subsidiary network dimensions impact the implementation of policies.

CEM literature has mainly focused on (1) home/host market institutions and the role they play in shaping firms' environmental behaviors (Aguilera-Caracuel, Aragón-Correa, \& Hurtado-Torres, 2011; Dasgupta, Hettige, \& Wheeler, 2000; Delmas \& Toffel, 2004; Henriques \& Sadorsky, 1996; Hoffman, 2001; Hurtado-Torres, 2011; King \& Shaver, 2001) as well as (2) internal firm resources, examining how specific firm-level capabilities are driving environmental behavior (Aragon-Correa \& Sharma, 2003; Chen, 2011; Christmann, 2000; 2004; Elsayed, 2006; Menguc, Auh, \& Ozanne, 2010; Russo \& Fouts, 1997; Waldman, Siegal \& Javidan , 2006; Waddock \& Graves,1997). Each of these main research streams has indeed contributed to our understanding of significant opportunities and challenges of CEM. Current literature relies mostly on dominate theoretical lenses of Institutional Theory, RBV, and Legitimacy/Stakeholder Theories (Berman et al., 1999; Cormier, Denis Gordon, \& Magnan, 2004). In light of this theoretical focus, lesser attention is given to challenges faced by headquarters in controlling the firm, and specifically to balancing the relationships between verbal environmental commitment, policy setting and actual environmental outcomes. Furthermore, building on the MNC as a complex network perspective, lesser theoretical attention is also given to the subsidiary network itself in CEM, which is (1) a strategic source of competitive advantage behind its "causal ambiguity" (Lippman \& Rumelt, 1982) and also a (2) mechanism for implementation of strategy (Ghoshal \& Bartlett, 1989; Holm \& Pedersen, 2000; Peng, 2001). Additionally, given the role of the 
subsidiary network as a facilitator of inter-unit learning as well as for streamlining and controlling global operations, it is likely to have an impact on the adoption of practices across the network. It is through their subsidiary networks that MNCs seek to communicate, control, coordinate, manage, and implement uniform adoption of practices, and failures of the network are likely to bring challenges to achieving this (Martinez \& Jarillo, 1991). Nevertheless, except for a few studies, the network theory lens is significantly underutilized in CEM (Haverkamp, Bremmers, \& Omata, 2010; Akiyama, 2010; Alexander, 1998).

\section{Research Question \#1: Managing Core Elements of CEM}

In Onkila‘s study (2009: 288), she cites Shrivastava (1995), stating that "Corporate environmental management (CEM) has been characterized as a context of complexity and uncertainty in which choices have to be made and the consequences of corporate action and different stakeholder views coped with." While previous literature focused on external sources of such complexities, I build on the work of Rugman and Verbeke (1998) who direct literary attention to corporate level strategy and the decisions made at the firm level in response to increased environmental pressures. "(T)hrough a complex web of constituents, environmental protection is becoming culturally refrained from something external to the market environment to something that is central to the core objectives of the firm" (Hoffman, 2001: 137). While some aspects are responses to regulation, CEM includes mostly voluntary and internally driven initiatives which, according to Sinding (2000), include a company's stand on environmental issues, operations and reporting policies, and finally a company's actual ecological footprint. 
Different scholars have individually examined different elements of the CEM process (Clemens \& Bakstran, 2010; Onkila, 2009; Schendler \& Toffel, 2011), but this study investigates in concert how these key elements of verbal commitment, green policy management, ecological performance and environmental reputation are interrelated as key CEM process components.

While earlier scholars put forth the argument of MNCs exploiting cost advantages from host markets with lax environment regulations known as "pollution havens" (Gladwin, 1987), Christmann (2004) explains that although such exploitation practices were common in the 1970s and 1980s, recent evidence depicts that MNCs are increasingly implementing more self regulation environmental policies (Brown, Derr, Renn, \& White, 1993; Dowell, Hart, \& Yeung, 2000). This green trend of firm behavior is no longer connected solely to external stakeholder pressures, but is driven by firms' self interest in doing so. Klassen and Mclaughlin (1996) found that the announcements of firms recognized as being environmentally conscious were directly linked to an increase in the market value of their shares traded in the stock exchange. Others documented significant benefits from being associated with being "green" (Hart, 1995; Dowell et al., 2000; Carnicross, 1992; Porter, 1990; Christmann 2004), which puts significant pressures on HQs to position their firms as "green" MNCs. But given the complexity a HQ faces in the strategy formulation process (Mcmillan 2004; Mintzberg \& Waters, 1985), there is often a situation where there may be a gap between a HQ's intentions manifested in their "intended" strategy and their actions manifested in their "emerged" strategy, which 
highlights the importance for a HQ role in controlling the organization. CEM scholars note that although many firms use strong provocative statements to highlight their commitment to the environment (Saha \& Darnton, 2005) to positively portray their green position in the market, that is not to say these firms are actually putting their words to substantial action (Laine, 2005). This indicates a need for us to understand how the MNC CEM core elements work together to impact environmental performance and HQ's role in this process.

Control refers to "any process (mechanism, instrument) applied by the organization to assure the execution of organizational goals and plans" (Ambos \& Schlegelmilch, 2007: 474). Control is a process "whereby management and other groups are able to initiate and regulate the conduct and activities so that their results accord with the goals and expectation held by those groups" (Child 2005: 112). Classical international business theories, specifically product life cycle theory and internationalization process theory, have all based their assumptions on the subsidiary being an instrument for implementation of HQ strategy (Birkinshaw \& Hood, 1998). Jamali (2010) describes that "even when MNCs try to adequately resource their subsidiaries in the context of a localized/decentralized CSR strategy, it becomes difficult to monitor and control them because of physical and cultural distance; hence issues of coordination and control become salient". The fact that the MNC operates in multiple competitive host markets "may increase the challenges of developing globally coherent CSR strategies and creating synergies among them" (Barin-Cruz \& Boehe, 2010: 248). Scholars highlight the importance of conceptualizing control in a manner that extends beyond only hierarchical 
top down decisions (Geringer \& Hebert, 1989), calling for a better understanding to unlock the different types of control mechanisms that firms use to guide actions (see, e.g., Chen, Park, \& Newburry, 2009, and Cardinal, 2001, re: Output, Process and Social Control). Geringer and Hebert (1989) borrow from Bartlett's distinction to show that some control mechanisms are (1) context-oriented/informal and (2) contentoriented/direct intervention from management in a bureaucratic fashion. Similarly, Geringer (1986) also reported that control has a scope dimension where he differentiates between narrow vs. wide control scopes. Therefore, HQ may choose to exert control over all activities or only select to control some activities of the organization (see, e.g., Choi \& Beamish, 2004; Newburry \& Zeira, 1999).

In light of these discussed challenges, the HQ needs to effectively and smoothly manage the CEM elements, making sure its formulated strategy is effectively implemented. Scholars noted that control is not an automatic consequence of ownership (Friedman \& Beguin, 1971).

\section{Headquarters' Role in CEM: Control Challenges}

Headquarters have key "administrative and leadership roles with regard to implementing corporate strategy, participating in divisional strategy formulation, coordinating the different divisions, and fostering overall cohesion, identity, and direction within the company" (Grant, 2008: 419). While it is important for MNCs to allow subsidiaries sufficient autonomy to respond to local market conditions (Newburry \& Zeira, 1999; 
Newburry, Zeira \& Yeheskel, 2003), headquarters are often responsible for effective management and monitoring of network members' local environmental actions, without jeopardizing the MNCs' goals of integration and standardization of operations (Roth \& Morrison, 1990). Birkinshaw and Hood (1998) explain that subsidiaries' prescribed mandates within the MNC are not stagnant; instead, subsidiaries undergo "subsidiary evolution", which is the result of capabilities being acquired and also being depleted over the life of the subsidiary, which makes it important for HQs to monitor subsidiaries' behaviors even after issuance of mandates. Although we are witnessing greater decentralization of decision making, HQ remains the key actor charged with controlling and coordinating the operations of the MNC, while subsidiaries are implementers (Roth \& Kendall, 1992). This is recognized as "hierarchical decision making" (O'Donnell, 2000). It is the parent firm's responsibility to issue the environmental responsibility reports reflecting its operations around the globe (Mohan, 2006), which are often highly scrutinized by stakeholders such as NGOs. Jamali's (2000: 193) findings support that although subsidiaries can choose local themes to support CSR initiatives, they are responding to the overall directions issued to them by headquarters. Managers in her study explain that "MNC 5 annually sets a theme for CSR at the global level and all MNC 5 offices perform CSR activities relating to that theme. The country offices come up with suggestions about the specific activities that can be performed within the general CSR theme, and these are communicated to the Middle East office. There are cooperative decision-making patterns within the network." 
However, the literature has also documented that given the complexity of managing the MNC, authoritarian HQ decisions/controls are not absolute determinants of firm actions. Subsidiary roles are defined by the interactions of different sources of influence: (1) head office assignment (the head office predetermines the subsidiary's capability), (2) subsidiary choice (through networks, subsidiaries can develop their own capabilities or by the subsidiary's autonomous managerial decision making process which determines their actions without the influence of their head office), and (3) determination by the local environment (Birinshaw \& Hood, 1998). Birkinshaw and colleagues (1998) reviewed these three sources of variations in subsidiaries' roles, and reported there was no conclusive evidence of which factor predicted subsidiaries' behavior most. In the first research question, this study will focus on the role of HQ in shaping subsidiaries' behaviors through a mix of control mechanisms.

Particularly to CEM, it is unlikely that uniform adoption of environmental polices is likely to be achieved smoothly via headquarters' top down decisions alone (Tsai \& Child, 1997). In their study of Indo-American joint ventures, Panda and Gupta (2003) found significant gaps between what leaders believed to be the "prevailing" company values/mission and that which other organizational members perceived to actually exist and also what these other members aspired for them to be. They attribute this to corporate executives' weak efforts in disseminating the values prescribed by these mission statements to all organizational members resulting in the incongruity between individual vs. corporate values. 
MNC control can vary on dimensions of formality by being either formal or informal (Harzing, 1999), manifested in "bureaucratic vs. personal surveillance and organizational culture". MNCs use a combination of mechanisms for goal alignment between their subsidiaries to monitor and control behaviors which include (1) launching of policies with coordination mechanisms that are either formal or subtle (Martinez \& Jarillo, 1991), and (2) the creation of a common corporate culture with shared values manifested through the process of socialization (Geringer \& Hebert, 1989). Headquarters can control the MNC by exercising three different types of controls, which are "centralization, where the decision-making power is retained at the headquarters; formalization, where decisionmaking power is routinized through rules and procedures; and socialization, whereby organizational members develop common expectations and shared values that promote like-minded decision making” (Ambos \& Schlegelmilch, 2007: 475).

This study seeks to explore the impact of a HQ's efforts in setting policies and using verbal communication to control its network of subsidiaries, specifically within the context of optimizing environmental performance. The upcoming research model investigates the corporate environmental management process and presents hypotheses for how each component of that process is related. The components of corporate environmental management investigated in this study are (1) an MNC's verbal environmental commitment, (2) an MNC's environmental management policies, (3) an MNC's actual environmental performance/ecological footprints and finally (4) the corporate environmental reputation the MNC has built for itself or others have associated 
with it (VMPR). Figure 1 depicts the environmental management elements to be investigated in this study, highlighting the key components of the corporate environmental management process of the MNC as described herein.

Figure 1

\section{Framework for Corporate Environmental Management VMPR}

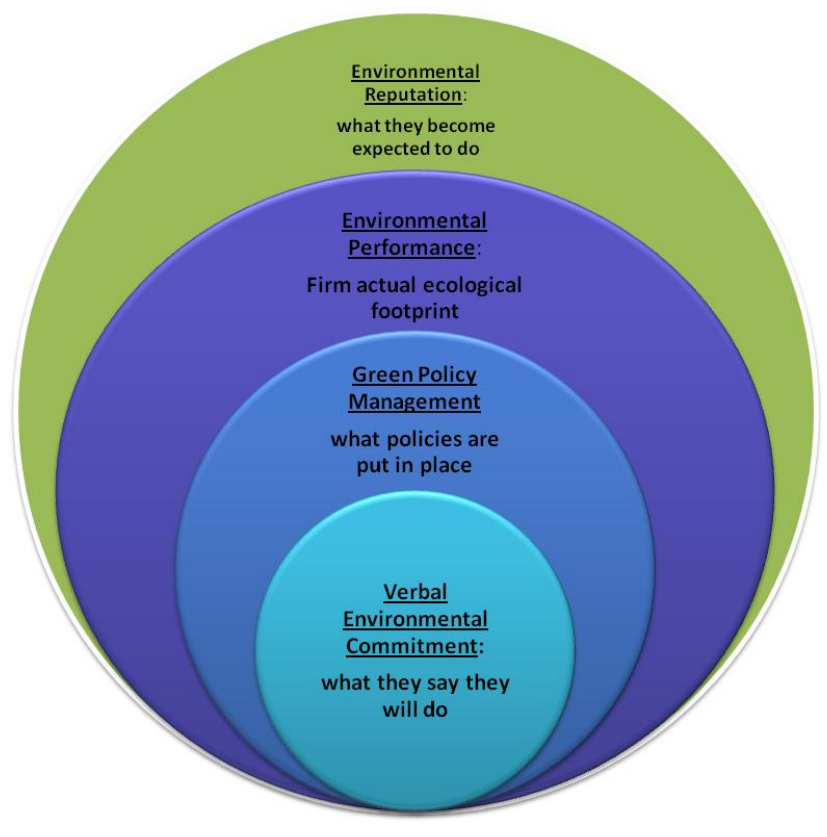

It is important to state that the purpose of Figure 1 is not necessarily to say that all firms' actions will follow the particular order shown below, which begins with verbal environmental commitment at its center (what firms say they will do) and progresses to environmental reputation as its outermost layer (what others say the firm does), but rather 
is an attempt to conceptualize the multiple aspects of the CEM process where each component is important for firms to effectively manage and control. The next section presents hypotheses predicting how these elements are related within the context of headquarters' efforts at controlling the organization. More specifically, the study explores the impacts of (1) informal socialization control mechanisms exercised through verbal environmental commitment and (2) formal control mechanisms exercised through green polices to drive green ecological footprints. The next section discusses these hypotheses.

\section{RQ\#1 HYPOTHESES}

\section{Informal Control: Verbal Environmental Commitment}

Companies can use informal control mechanisms, like informal communication and socialization efforts (Chang \& Taylor, 1999), to implement corporate values using multiple means for communicating these values. O'Donnell (2000: 531) explains that "the cooperative behaviors needed in conditions of high international interdependence are best facilitated through social control methods". Birkinshaw, Hood and Jonsson (1998) proposed that firm leadership predicted positively subsidiary initiative and the subsidiary's contributory role in achieving MNC goals. Informal communication control mechanisms can allow MNCs (1) to communicate to all stakeholders what the company cares about and plans to be committed to (King, Case, \& Premo, 2010), which creates a common culture, and also (2) serves as an initial step in building firm reputations reflecting these core values. Birkinshaw and Hood (1998) found parent's management 
ethnocentrism, which refers to the parent's sense of national superiority over subsidiaries, to have a direct impact on the actions of subsidiaries and the role they play within the network.

Because firms' actual actions are often guided by their communicated actions, in essence, what the firm "says" it believes are important issues is likely to give some indication of what factors it is likely to act upon and seek to implement, which helps get everyone on the same page of what strategic actions are likely to be taken. Mintzberg and Waters (1985) explain that purely deliberate HQ strategies are those where the HQ has communicated their intentions for these actions, which need to be "articulated in a relatively concrete level of detail, so that there can be no doubt about what was desired before any action was taken" (Mintzberg \& Waters, 1985). Such intentions must be collectively shared by all actors and also realized as intended.

Therefore, a key step to controlling global operations and becoming a globally environmentally conscious company would be to articulate or verbally communicate concerns for environmental consequences or issues, reflecting the firm's intentions towards the environmental issues. Firms will often use verbal commitments to different issues to present an image to all stakeholders that will guide the behavior of their employees and partners. Hart (1995) proposes that MNCs who are more capable at establishing a shared vision are more likely to acquire the resources needed for sustainable development. Mission statements can determine firm actions when there is "organizational involvement in interpreting, refining, and making it operational" (Bartlett 
\& Ghoshal, 1994: 82). Onkila's (2009: 285) study of Finnish firms reveals that firms' environmental statements were used to increase acceptability of the firms' environmental behaviors using three forms of rhetoric, each depicting a different relationship between the corporation and its stakeholders, which she defines as rhetoric of (1) dominance, (2) subordination and equality and (3) joint action.

Mission statements are ways by which a firm can identify itself to stakeholders (King, Case, \& Premo, 2010). They serve as mechanisms by which a company can describe its "reason for being" (David, 2009). Mission statements are a form of corporate communication that sets "the framework or context within which the company's strategies are formulated" (Hill \& Jones, 2008: 11) and therefore sets the strategic direction of the firm (Sattari, Pitt \& Caruana, 2011) and indicates the types of practices or objectives the firm is committed to. Bartlett and Ghoshal (1994: 82) explain that "the statement must be broad enough to invite - and indeed require - the organizational involvement in interpreting, refining, and making it operational. In practice, this means tapping into the reservoir of knowledge and expertise that is widely distributed throughout the company". Campbell (1992) explains that for mission statements to impact actual day to day operations, organizational members need to develop emotional commitment to the firm's purpose as specified by the mission statements. For the MNC, the translation of mission statements to guide actual behaviors is challenged by its diverse and dispersed organizational members. Although subsidiaries may superficially identify with the values of the mission statements, a strong cohesive organizational culture as well 
as individual units' engagement in formulating these mission statements is needed to substantiate the actual practices to follow.

Firms' environmental commitment can also be found in their websites and other environmental online reports issued (Branco \& Rodrigues, 2008; Sinclair \& Walton, 2003). Furthermore, Onkila (2009) highlights the importance of understanding the

environmental rhetoric of firms, stating that this "language" aspect of corporate environmental management (CEM) is "missing". Given the important role of corporate communication as an informal control mechanism, one would expect those that verbally communicate environmental concerns are more likely to enforce their voiced commitment (Bartkus \& Glassman, 2008).

Accordingly, I hypothesize;

H1: There is a positive relationship between MNCs' environmental verbal commitment and their global environmental performance.

\section{Formalization: Green Policy Management}

Nobel and Birkinshaw (1998) explained that firms use three modes of control over their dispersed units: (1) centralization, where HQ makes all the decisions, (2) formalization, where there are established rules and guides that determine behavior, and finally (3) socialization, where the firm seeks to create an informal setting where shared values can lead to increased possibilities of similar decision making. Each of these modes is 
“complementary and competing" (Nobel \& Birkinshaw, 1998: 483). In the context of CEM, the previous hypothesis discussed a mechanism of socialization. Yet, while a majority of leading firms may issue mission statements to reflect their commitment to different social issues, this is not to say they can be described as "effective mission statement(s)" that will control subsidiaries' behaviors (Panda \& Gupta, 2003: 24). Deliberate strategies rely on heavily detailed planning as well as the establishment of formal control mechanisms (Mintzberg \& Waters, 1985). While the term "environmental policy" traditionally has been used to describe how governments or NGOs set policies regarding how firms should behave towards the environment, I build on the work of Rugman and Verbeke (1998), who direct literary attention to corporate level strategy and the decisions made at the firm level in response to increased environmental pressures. While it is important for the firm to verbally communicate in its vision or mission statements the degree to which it cares for community and environmental issues, if such commitment is not transferred to setting actual firm environmental management policy to make that commitment substantial, then it remains "superficial" and less likely to become implemented. Utilizing the formalization mechanism of control, today, many MNCs have established well defined and strict guidelines for all aspects of operations, some of which extend beyond their subsidiaries to all members of their supply chain including suppliers and distributors. Hart (1995) explains that for firms to develop green competitive advantages they must adopt best environmental practices at all stages of the product life cycle. He describes environmental management as including (1) pollution prevention which occurs at the production and operations stage, (2) product stewardship which requires including the environment as a key stakeholder in the design and development 
stage, and finally, (3) sustainability development, where corporations work on building the bridge between environmental and economic consequences in developing countries.

Environmental management control not only refers to setting operational standards, but also to guidelines in reporting company environmental practices. In 2008 , almost $80 \%$ of the Fortune 250 firms issued "stand alone" sustainability reports (KPMG, 2008). This trend of so called "value reporting" (Livesey \& Kearins, 2002), which is mostly voluntary, has become an integral part of corporate communication. For these firms, it is not enough to simply communicate verbally their commitment to the environment, but they have also committed to specific reporting guidelines to show stakeholders they are acting on their word and enforcing environmental commitment. Examples of firms' successful environmental policy programs include 3M's 3Ps (Pollution Prevention Pays) and Dow's WRAP (Waste Reduction Always Pays) (Smart, 1992). Alongside this trend is the increased number of agencies whose function is to report to investors how effective firms' environmental polices really are. MSCI ESG (environmental, social, and governance) Research is one of the leading ranking agencies. They provide the Global Socrates database, and recently developed the "Green Policy" score, measuring the effectiveness of firms' management of their environmental policies. Similarly, although providing data for a smaller sample, the Dow Jones Sustainability Index "focuses on operational impacts such as pollution levels and regulatory compliance, as well as the presence or absence of environmental management practices affecting operations (such as environmental auditing) and stakeholder engagement (such as environmental reporting)" (Schendler \& Toffel, 17-18: 2011). 
Building on the discussed importance of verbal environmental commitment as an informal control mechanism and policies as a formal control mechanism, one would expect those companies with verbal commitment to environmental performance would more likely be the firms having effective environmental management policies to guide their global behaviors. Accordingly, I hypothesize;

H2: There is a positive relationship between environmental verbal commitment and green policy management.

For many of the leading firms that seek benefits from having environmental policies, the benefits can range from mere compliance with regulations, building overall legitimacy of operations, and achieving green competitive advantages over peers, to effective actual environmental performance measured by their ecological footprint (Clemens \& Bakstran, 2010). Given the trend of self regulation that describes the majority of leading firms' behaviors, one would expect those firms that have in place environmental policies/standards are more likely to behave environmentally consciously than those who do not have such policies or those that have weaker policies.

Because of the level of interdependence between MNCs' globally dispersed operations, and the benefits from standardization of global operations, it would make sense for MNCs to seek to have corporate policies that translate to wide MNC actions. In fact, this is one of the reasons why MNCs are expected to address environmental issues. MNCs 
can leverage their networks to maximize environmental performance, which other local firms and governments may not be able to address to the same degree (Hart, 1995). Accordingly, I hypothesize:

H3: There is a positive relationship between firm green policy management and global environmental performance.

\section{Signaling: Environmental Reputation}

A firm's reputation is the "perceived capacity to meet their stakeholders' expectations" (Waddock, 2000: 323). It refers to the overall knowledge and esteem about a corporation held by the public (Fombrun \& Shanley, 1990; Newburry, 2010). Although perceptions of firm behavior are a key component in determining a firm's reputation, its actual behavior is perhaps even more critical. Corporate social performance and financial performance are the two main drivers of a firm's reputation (Fombrun, 1990; Soleimani, 2011). Signaling theory explains that stakeholders will formulate an image of expected firm behaviors based on limited information (Myers \& Majluf, 1984; Behrend Baker, \& Thompson, 2009). Reputation is determined by how the audience reacts to the different organizational signals (Love \& Kraatz, 2009). Citizens will often "anthropomorphize organizations", that is giving them traits as conscious actors rather than just as collective entities which are expected to act as "coherent and social entities" (Love \& Kraatz, 2009). Accordingly, firms need to not only act today in accordance with stakeholders' current expectations, but they need to also meet expectations regarding their future actions to allow stakeholders to develop an underlying degree of trust that a company will 
look out for their best interests continuously. This makes a firm's reputation serve not only as an information signal, but also as an underlying reflection of the organization's character, whereby trust, as a guarantee of contracts between the firm and its stakeholders, is an integral part (Cornell \& Shapiro, 1987).

Scholars have shown that organizational behaviors can lead to significant changes in how an audience perceives a firm (Love \& Kraatz, 2009). Not only does verbal environmental communication serve as a way to bind the firm to take actions that reflect such verbal commitment, but it also sets the expectations of external actors in terms of expected environmentally conscious behaviors from this firm. Scholars found pro-environmental corporate messages had an impact in attracting potential employees (Behrend, Baker, \& Thompson, 2009). Furthermore, even if the firm's environmental actions in one host market do not directly impact its operations in another, corporate environmental reputation can still be affected (Christmann, 2004). Christmann (2004) explains that MNCs will standardize the content of their corporate environmental communication across subsidiaries to make it appear that they all follow the same environmental operations policies, and in doing so, use external public pressure to enforce subsidiaries' substantial adoption of the environmental values communicated. Although reputation is in fact externally perceived and therefore not directly controlled by managers, firms who have communicated verbally and have put in place policies that support environmental protection are likely to build their reputations compared to those that do not. While contrary to our arguments, Cho and Coleefus (2012) recently found a negative relationship between environmental performance and environmental reputation among 
poor environmental performing firms who come from highly polluting industries. Nonetheless, the next hypotheses are:

H4: There is a positive relationship between environmental verbal commitment and global environmental reputation.

H5: There is a positive relationship between green policy management and environmental reputation.

H6: There is a positive relationship between global environmental performance and environmental reputation.

\section{CEM CONTROL IN PERSPECTIVE}

Setting environmental policies does not automatically mean effectively complying with these policies. The MNC is confronted with various challenges which make successful global environmental performance unlikely to be smoothly adopted (Tsai \& Child, 1997). In fact, many firms have a number of polices in place more for impression management purposes (Bansal \& Kistruck, 2006) rather than actually restricting operations. Christmann and Taylor (2006) find that some firms will select "symbolic implementation" of environmental best practices rather than actual implementation depending on where self interest lies (Westphal \& Zajac, 1994). Scholars also found that firms with ISO 14000 certifications were not necessarily those having effective actual environmental performance. While such certifications are meant to guide the 
environmental behaviors of firms, the evidence of such a relationship is inconclusive (Potoski \& Prakash, 2005; Andrews et al., 2003). In fact, King et al. (2005) found that firms with certifications actually had lower environmental performance. Christmann and Taylor (2006: 866) explain that firms that "pursue symbolic implementation do not use the certified management system in their daily operations, and make last-minute efforts to prepare for certification audits. For these firms the standard serves a symbolic purpose".

In light of the discussion provided by Mintzberg and Waters (1985) on the difference between deliberate vs. emergent strategy, it is likely there will be some CEM strategic elements that are more deliberate than others. It is on this basis that Figure 2 further distinguishes between components of the VMPR framework, whereby some elements of CEM are likely to be under more direct and deliberate influence by HQ, which seeks to get them to be collectively honored. Other elements of CEM strategy are likely to lie more on the continuum towards the emergent side where the HQ is likely to have less direct control or influence on the outcome. Verbal communication and setting environmental policy management are both internal to the firm. They are to a significant degree actions controlled by management. Christmann's (2004) examination revealed that corporate environmental communication content and environmental management standards are two dimensions of the environmental management process that MNCs can standardize. However, the other components of the environmental management process which have to do with actual global implementation of environmental policies in order to achieve (1) environmental performance and eventually obtain (2) environmental 
reputation (Fombrun \& Shanley, 1990) are both less directly controlled by HQ and therefore are subject to greater uncertainty.

Figure 2

\section{CEM and Strategy Formulation Types}
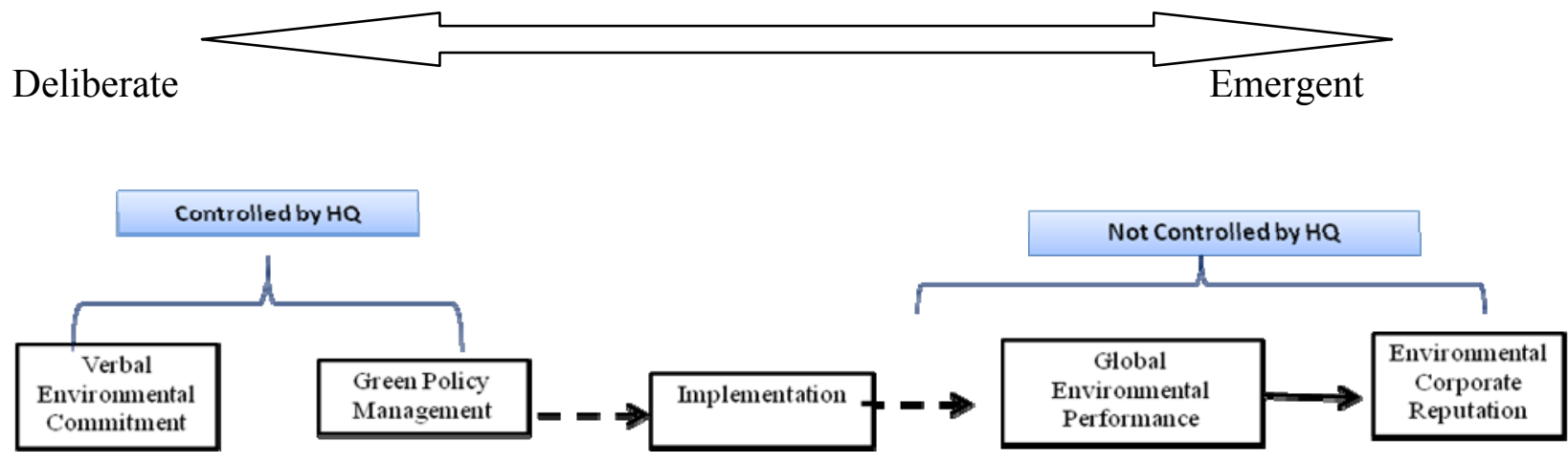

Through this analytical approach to understanding the environmental management process, this study takes a comprehensive approach capturing different aspects of environmental strategy prior to investigating the complexities of the MNC network dimensions which are hypothesized to hinder the smooth flow of the environmental management process. The framework captures the CEM strategic management process, discussing elements of strategy formulation (verbal environmental commitment and policy) and implementation (GEP) in one study. In doing so, this framework attempts to answer the first research question: How do the internal elements of the CEM process work together to impact global environmental performance? 


\section{Research Question \#2: Challenges from subsidiary network dimensions}

In addition to the "corporate image" motivation to not following through on policies, firms may also face significant structural challenges that act as barriers to their substantial implementation of policies. Christmann (2004: 751) explains that "in MNCs it is even more challenging for environmental managers at corporate headquarters to get subsidiary managers' support for implementing standardized environmental policy". In an in-depth empirical analysis of eight cases in two MNCs drawn from diverse business sectors, MNCs did have clearly stated social and environmental objective mission statements and specific policies set at their parent companies (Mohan, 2006). However, they were found to have variations in CSR practices across MNC subsidiaries in different countries and across MNC subsidiaries within the same country (Mohan, 2006). These findings indicate that there is likely to be a gap between what a HQ seeks to deploy and what network members eventually adopt. Therefore, it is important to examine how the green management policies to actual performance relationship is impacted by important dimensions of MNC networks, which by default can raise complexities in implementing policies, even if the MNC had intentions of substantiating them.

While scholars have drawn linkages to the interrelationships between MNC internationalization elements and environmental performance (Rugman \& Verbeke 2001; Christmann 2004; King \& Shaver, 2001), there is a need for theoretical and empirical studies to indicate what elements of the inter-organizational network are likely to explain this linkage. From a classic strategy angle, the unsettled debate between strategy and 
structure (Wolf \& Egelhoff, 2002) is also relevant here, where the question remains: does the MNC have in place the proper network structure needed to effectively achieve global environmental performance? Taking a network perspective to analyze environmental management challenges is likely to reveal interesting insights, given that many believe we are witnessing an era in which networks play a prominent role that may even "replace markets and hierarchies" (Alter \& Hage, 1993; Castells, 1996; Raab \& Kenis, 2009).

\section{Network Theory}

An organization can be conceptualized as a network in which organizational units are nodes interacting with each other, establishing formal and informal relationships (Brass et al., 2004: 800). It is through networks that MNCs can reach strategic objectives, utilizing the networks as mechanisms for gathering, processing, and transferring knowledge and other strategic resources across markets (Ghoshal \& Bartlett, 1989; Holm \& Pedersen, 2000; Peng, 2001). Grant (1991) explains that the degree of interunit cooperation is facilitated by the network, which transforms firm resources into capabilities. It is this conglomeration of the individual members' resources that will give a parent a competitive advantage that would be too complicated if not virtually impossible for competitors to imitate, behind their "causal ambiguity" (Lippman \& Rumelt, 1982). Subsidiaries of the MNC function as a social system of "interrelated units that are engaged in joint problem solving to achieve a common goal" (Rogers, 2003: 23). Network theory's interest is in identifying the emergent order or patterns of complex organizations and how they work rather than the underlying causes of the complex organization's behavior (Brodbeck, 2002; Mischen \& Jackson, 2008). 
As explained by this theory, what is unique about analyzing the network is that the summation of the parts does not equal the whole (Anderson, 1999; Levinthal, 1997). Instead, "the existence of whole networks points to the fact that something is produced by the network which no single participating organization could be doing on its own and that therefore also collective goods are produced at least for the network members" (Raab \& Kenis, 2009: 207).

\section{Strategic Importance of the Network}

MNCs that are able to effectively capitalize on their networks as sources of competitive advantages are more likely to meet global strategic objectives. Brass and colleagues (2004) explain that effective MNC subsidiary network interunit ties lead to improved (1) performance for the organization and (2) innovation and knowledge activities. In effective network structures, firms have access to each other as a resource. Therefore, firms are able to maximize benefits from interunit information exchanges and achieve overarching distinctive, intangible, and non imitable capabilities for the MNC as a whole. The degree to which subsidiaries relate to one another makes up the MNC group norms, which impact the practices that get introduced and eventually diffused among members (Rogers, 2003; Nelson \& Winter, 1982). Through interunit exchanges of acquired knowledge, MNCs build their competencies (Zander \& Kogut 1995; Szulanski, 1996). MNC network structures can support the "exploitation and creation" of core competencies (Prahalad \& Hamel, 1990), which can be upgraded when such competencies are transferred between units (Andersson, Forsgren \& Holm, 2001). The way an MNC network is designed has a key role to play in facilitating these interunit 
linkages. In fact, the degree to which MNCs are able to achieve expected synergies set by their global integration strategies is often a function of the limitations inherent in their inter-organizational structures (Galbraith \& Kazanjian, 1986; Ghoshal \& Bartlett, 1990; Stopford \& Wells, 1972). "Organization theory has treated complexity as a structural variable that characterizes both organizations and their environments" (Anderson, 1999: 216). Therefore, networks that are structured to facilitate a smoother exchange of ideas between units create a stronger common culture of best practices across the network members and smoother adoption of policies. These networks are more likely to maximize the absorptive capacity of their members and more likely to uniformly adopt environmental policies. This is in comparison to other MNC network structures which may be less well organized to facilitate such smooth diffusion of practices between the MNC network members.

While the application of network theory to the CEM literature is relatively new, it is important to also shed some light on the potential of this growing direction exemplified by the very few recent studies that have used a network theory lens to examine CEM. Haverkamp Bremmers and Omata (2010) examine how the firm's external network interrelatedness impacts environmental management capability deployment in the Dutch food and drink industry. Akiyama's (2010) case analysis of the environmental management of a construction company revealed that the denser and stronger the interorganizational network ties among workers, the more internalized the CSR/environmental values became among workers. Alexander's (1998) study used cases 
in environmental management to present a structuration theory of interorganizational network coordination to illustrate the possible variations of coordination structures.

\section{Network Complexity and Environmental Performance}

Furthermore, Aragón-Correa and Sharma (2003) generally proposed that the degree of complexity moderates the relationship between a firm's capabilities and actually developing an effective and proactive environmental strategy, leading to competitive advantage. The upcoming second set of hypotheses specifically investigates the complexities brought about when we incorporate the effects of MNC subsidiary network dimensions as depicted by Figure 3. Network effects are argued to bring about complexities mainly where a firm has less control, making the firm more vulnerable to having their strategy be shaped by external elements which they did not directly intend or forecast. This is explained to be most evident at the point of translation between green policy management and actual GEP, which is the implementation stage of the process. 
Figure 3

\section{Corporate Environmental Management Control}

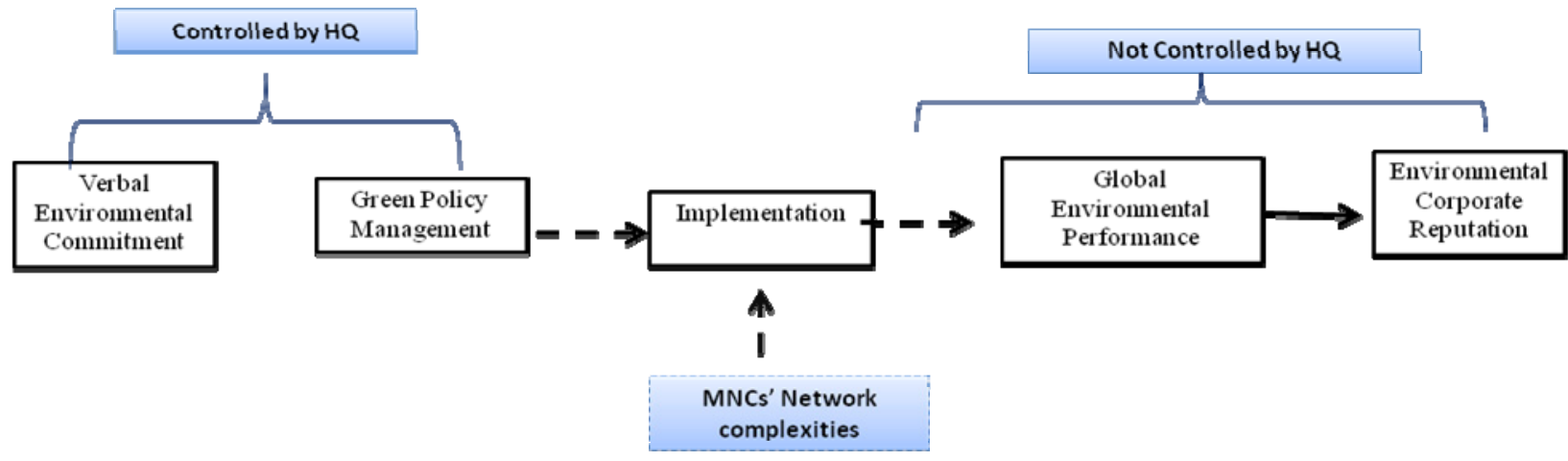

\section{The Impact of Network Dimensions}

Earlier work on strategy-structure fit explains that firms' international structure should be designed to meet the objectives stated by their strategies (Chandler, 1962, 1998; Pitts, 1977; Miller, 1987; Stopford \& Wells, 1972; Wolf \& Egelhoff, 2002). For the MNC that has adopted a global environmental policy, if the subsidiary network is not well designed to serve its prescribed role, then it becomes a constraint (Ghoshal \& Nohria, 1989) to deploying uniform practices. As MNC subsidiary networks become larger and more complex, so are the difficulties of managing, coordinating and streamlining their behaviors, making global environmental performance challenging (Rugman \& Verbeke, 1998). The greater the degree of interdependence between subsidiaries, the higher the need is to control their behaviors, which can occur through socialization, formalization, and centralization (Ambos \& Schlegelmilch, 2007). Hart (1995) explains that for MNCs 
to adopt a product stewardship strategy, they must be able to effectively manage and coordinate between the different functional units. Increasingly, MNCs are under more pressure to satisfy multiple stakeholders across different host markets (Mohan, 2006) as well as facing home-based pressures to meet environmentally conscious behavior expectations. MNCs are "subject to both divergent and convergent pressures as a result of the different institutional contexts of their home countries, host countries and global industries" (Kolk, 2005: 147; Kostova, 1999).

Subsidiaries are challenged with "institutional duality", which reflects pressures from both home and host country institutions (Kostova, 1998). Subsidiaries are more likely to superficially adopt a parent led practice when there is (1) uncertainty of outcome as well as (2) legitimacy pressures for such practices to be adopted (Kostova \& Roth, 2002). MNCs are also under home-based pressures to effectively manage and monitor their internal subsidiary networks' environmental actions, while allowing their subsidiaries sufficient autonomy to respond to local market conditions, without jeopardizing MNC goals regarding integration and standardization of operations. Rugman and Verbeke (1998) argue that home country effects cannot alone predict environmental policies, because being environmentally conscious in a home market requires investment in unique projects, which may not be transferable to other markets. But focusing on the host market alone does not provide us a full understanding of what drives MNC environmental behaviors either. Since the MNC has multiple host markets that operate via a network fashion, it would be difficult to isolate the impact of one host market over another. Scholars have noted that the behavior of complex systems is surprising and difficult to 
predict (Daft \& Lewin, 1990) because of the many interdependent and nonlinear relationships between units (Casti, 1994), such that the "whole can be very different from the sum of the parts" (Anderson, 1999: 217). Hoffman (2001:146) explains that the difficulties of examining the multiple sources of cognitive and normative pressures that simultaneously exist within the organization is the reason why network analysis is regarded as "the most reliable way to empirically measure institutional phenomena" when examining diffusion of environmental practices.

The next section will draw from the HQ-subsidiary management literature and specifically the network conceptualization of the firm to examine the impact of three key network structure dimensions on the relationship between Green Policy Management and actual GEP.

\section{RQ\#2 HYPOTHESES}

Diversity is defined as the degree of dissimilarity between network members on dimensions related to industry scope and/or host market context (Tsai, 2000, 2001; Varadarajan \& Ramanujam, 1986; Mauri, 2009; Jackson \& Deeg, 2008). Scholars have documented the importance of similarity in facilitating communication and knowledge sharing (Grandovetter, 1985) as well as for the formation of aligned interests and common values. MNCs which have a high degree of institutional similarity between their units are likely to face lesser challenges deploying a uniform environmental commitment policy. When units share common grounds, they are likely to be more willing to adopt the 
environmental policies initiated by headquarters or by sister firms. The comparison to this would be an MNC that has high diversity among its units in institutional contexts whereby it becomes harder for the network members to agree to adopt uniform environmental policies, creating a situation of having a mix of adopters and non adopters among units of the same MNC. Aguilera-Caracuel, Aragón-Correa and Hurtado-Torres (2011) find that firms with low environmental institutional distance between home and host markets actually were more effective in setting environmental standards within the company.

Scholars highlight the importance of IB research that examines the diversity across "institutional landscapes". Jackson and Deeg (2008: 543) explain that "rather than treating institutional diversity in terms of its "distance" from the norms of an MNE's home country or ideal-typical liberal markets, the comparative capitalism approach has developed a theory of comparative institutional advantage in which different institutional arrangements have distinct strengths and weaknesses for different kinds of economic activity". They explain further that "institutions are seen not only as constraints but also as resources for solving key problems of economic coordination through non-economic, value-rational sets of commitments" (Jackson \& Deeg, 2008: 543).

Kostova and Roth (2002) explain that subsidiaries face conflicting forces due to institutional duality which sometimes can lead them to only superficially adopt a management practice that the parent wants, but in actuality not implement it. Rugman and Verbeke (1998) explain that it is likely that different units will have different 
perceptions regarding the adoption of environmental policies. Rugman and Verbeke (1998) argue that home country effects cannot alone predict environmental policies, because being environmentally conscious in a home market requires investment in unique projects, which may not be transferable to other markets. King and Shaver (2001) reveal that firms' actions are shaped by the host markets they operate within. Having variations in host market environmental institutions and regulatory contexts increases the difficulties of uniform adoption and the chances that each subsidiary will adopt its own environmental policy. Christmann (2004) highlights that setting global uniform standards for MNCs' environmental performance is complicated by the fact that they operate in varying regulative contexts, environmental infrastructures, and levels of workforce education (Brown et al., 1993; Rappaport \& Flaherty, 1992). Therefore, the greater the diversity in the network, the greater the complexities that can hinder the deployment of an MNC-wide uniform environmental policy needed to have global environmental performance. Accordingly, I hypothesize:

H7: The relationship between green policy management and global environmental performance will be negatively moderated by the degree of MNC institutional network diversity, such that the higher the institutional network diversity, the less positive the relationship between green policy management and global environmental performance.

Geographic Dispersion deals with examining the impact of physical geographic distance between subsidiaries and their parents (Markides, 1995, Ghemawat, 2001, Mauri, 2009) 
on effective network management. As MNCs continue to expand into new markets, they are likely to be challenged with the disadvantages of having highly physically dispersed networks. The MNC's competitive advantage depends to some extent on its ability to integrate value chain activities among its subsidiaries (Porter, 1985), which requires a large degree of coordination and communication between subsidiaries and increased interdependencies among units (Martinez \& Jarillo, 1991). Such integration efforts are often made more difficult by greater physical distance (Ghemawat, 2001). MNCs with distant units are more likely to incur higher information processing costs in order to coordinate across diverse contexts and deploy a standardized environmental performance policy. They are also likely to be more challenged by costs associated with imperfect knowledge flows, making it more difficult to streamline operations across countries (Carayol \& Roux, 2009; Ghemawat, 2001; Markides, 1995). Furthermore, scholars have shown an inverse relationship between geographical distance and the formation of social ties/exchanges, which are important for all units to share the same level of commitment to environmental policy (Bouquet \& Birkinshaw, 2008; Brass, et al., 2004). Based on this, it is likely that MNCs with highly dispersed network structures will find it more complex/challenging to coordinate and deploy uniform policies across many distant units, causing their environmental performance to suffer. Accordingly, I hypothesize:

H8: The relationship between green policy management and global environmental performance will be negatively moderated by the degree of $M N C$ network geographic dispersion, such that the higher the geographic dispersion, 
the less positive the relationship between green policy management and global environmental performance.

Density is defined as the number of foreign units in the MNC network that share a parent and are competing for resources from the same parent (Ghoshal \& Bartlett, 1990; Gomes \& Ramaswamy, 1999; Miller \& Eden, 2006; Pantzalis, 2001). Having many units also translates into many challenges, not only in increasing an MNC's liabilities of foreignness (Zaheer, 1995; Mezias, 2002), but also the challenges in streamlining operations and standardizing environmental best practices. In addition, the larger the number of units in the network, the more challenging it is for the MNC to keep tabs on the environmental footprints of each and every one of them. Schotter and Beamish (2011) explain that subsidiary to parent conflicts are no longer regarded as "dysfunctional" resulting from ineffective global integration, but are currently considered a "normal" aspect of managing the MNC network. King and Shaver's (2001) findings support that foreign firms face difficulties in managing environment behavior in foreign countries. Therefore, I hypothesize that overall, a larger number of foreign subsidiaries as compared to having an $\mathrm{MNC}$ network with fewer subsidiaries is likely to make it more challenging for the MNC to environmentally perform as a whole and increases the challenges of applying uniform environmental policy. Thus:

H9: The relationship between green policy management and global environmental performance will be negatively moderated by the degree of $M N C$ 
network density, such that the higher the density, the less positive the relationship between green policy management and global environmental performance.

Figure 4 summarizes the hypotheses discussed in the previous sections 
Figure 4

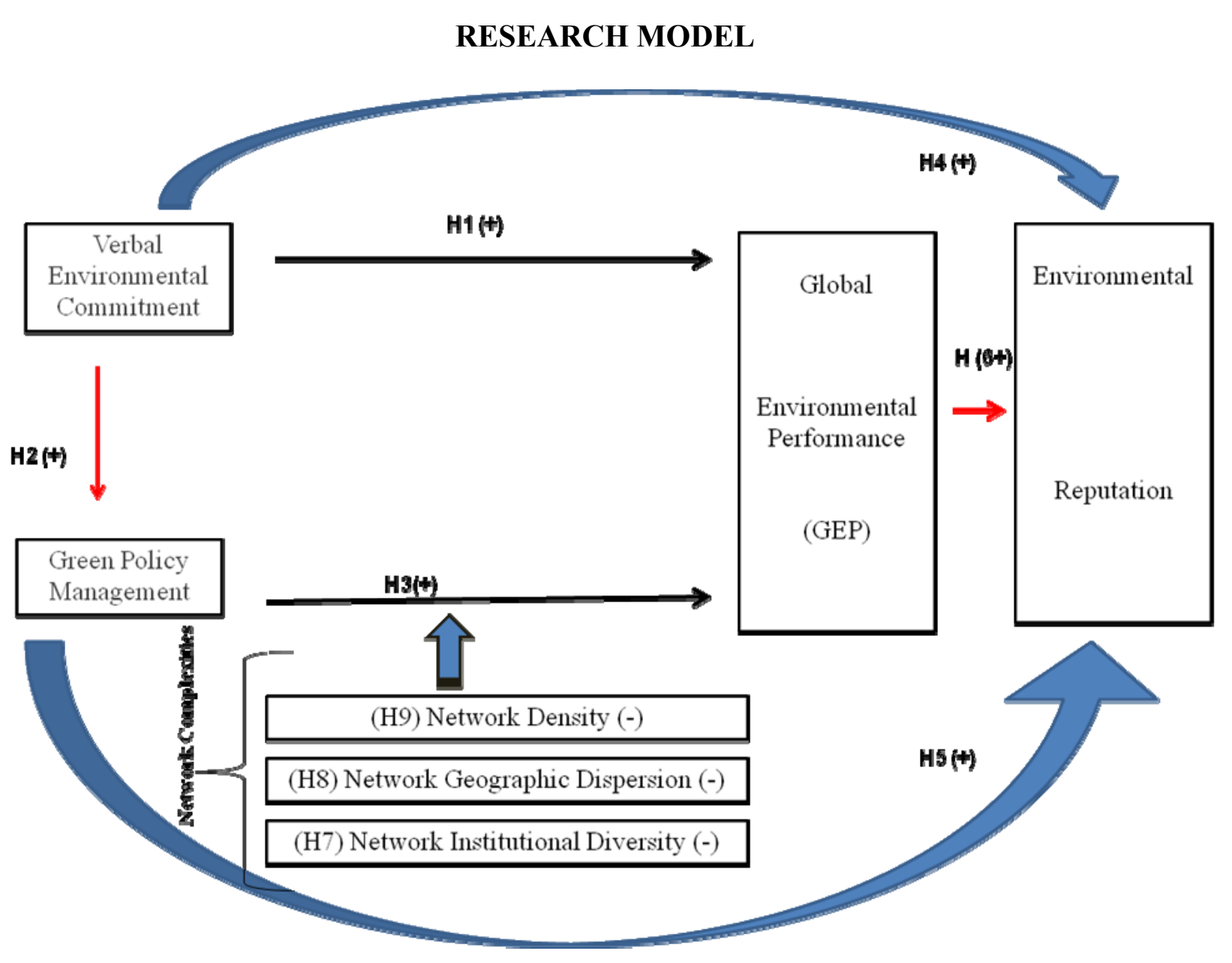




\section{DATA \& METHODS}

The sample for this study is drawn from the list of Fortune 500 US companies, which are all rated by Newsweek Green annual Ranking. The list of 500 firms includes both service and manufacturing firms. The study focuses on manufacturing sector firms covering SIC codes 2000-3999, which reduces the potential sample to 184 firms. Table 1 shows the sample split by sector for these 184 firms and the final sample. The data on their foreign subsidiary networks is collected from the Merchant Online database of corporate hierarchies in 2010, which reports data on public parent firms and all subsidiaries in the hierarchy. The foreign subsidiary network data for each MNC was used to calculate the network variables discussed below. Only subsidiaries with at least 51\% ownership are included in the analysis. When a company had multiple subsidiaries located in a foreign country, the country was counted only once. The unit of analysis is the MNC. Only MNCs that have a minimum of at least 2 foreign subsidiaries are included in the sample. My sample was further reduced to 164 because 20 firms did not have at least one foreign subsidiary. After deleting cases due to missing variables, the final analysis was conducted on a sample of $n=99$ for models testing Verbal Environmental Commitment (VC) and $\mathrm{n}=159$ firms for all other models. Appendix 1 provides a list of firms in the sample. 
TABLE 1: Sample Split by Sector

\begin{tabular}{|c|c|c|c|c|}
\hline & $\begin{array}{r}\text { Total Sa } \\
\quad \mathrm{n}=18\end{array}$ & & Final & \\
\hline Sector & Number of Firms & Percent & $\begin{array}{l}\text { Number } \\
\text { of Firms }\end{array}$ & Percent \\
\hline 2800 - Chemicals and Allied Products & 29 & $16 \%$ & 23 & $16 \%$ \\
\hline $\begin{array}{l}3500 \text { - Industrial and Commercial Machinery and } \\
\text { Computer Equipment }\end{array}$ & 28 & $15 \%$ & 23 & $15 \%$ \\
\hline $\begin{array}{l}3600 \text { - Electronic and Other Electrical Equipment } \\
\text { and Components Except Computer Equipment }\end{array}$ & 22 & $12 \%$ & 16 & $11 \%$ \\
\hline 2000 - Food and Kindred Products & 21 & $11 \%$ & 18 & $12 \%$ \\
\hline 3700 Transportation equipment & 18 & $10 \%$ & 14 & $10 \%$ \\
\hline 3800 Instruments and related products & 18 & $10 \%$ & 14 & $10 \%$ \\
\hline 2900 - Petroleum Refining and Related Industries & 10 & $5 \%$ & 8 & $6 \%$ \\
\hline 2600 - Paper and Allied Products & 9 & $5 \%$ & 7 & $5 \%$ \\
\hline $\begin{array}{l}3400 \text { - Fabricated Metal Products Except } \\
\text { Machinery and Transportation Equipment }\end{array}$ & 6 & $3 \%$ & 5 & $3 \%$ \\
\hline 2100 - Tobacco Products & 4 & $2 \%$ & 2 & $1 \%$ \\
\hline 3300 - Primary Metal Industries & 4 & $2 \%$ & 2 & $1 \%$ \\
\hline 2500 - Furniture and Fixtures & 3 & $2 \%$ & 3 & $2 \%$ \\
\hline $\begin{array}{l}3000 \text { - Rubber and Miscellaneous Plastics } \\
\text { Products }\end{array}$ & 3 & $2 \%$ & 3 & $2 \%$ \\
\hline 2200 - Textile Mill Products & 2 & $1 \%$ & 1 & $1 \%$ \\
\hline 3200 - Stone, Clay, Glass and Concrete Products & 2 & $1 \%$ & 2 & $1 \%$ \\
\hline 3900 Miscellaneous manufacturing industries & 2 & $1 \%$ & 2 & $1 \%$ \\
\hline $\begin{array}{l}2300 \text { - Apparel and Other Finished Products } \\
\text { Made from Fabrics and Similar Materials }\end{array}$ & 1 & $1 \%$ & 1 & $1 \%$ \\
\hline $\begin{array}{l}2400 \text { - Lumber and Wood Products Except } \\
\text { Furniture }\end{array}$ & 1 & $1 \%$ & 1 & $1 \%$ \\
\hline 2700 - Printing, Publishing and Allied Industries & 1 & $1 \%$ & 1 & $1 \%$ \\
\hline Total & 184 & $100 \%$ & 146 & 100 \\
\hline
\end{tabular}




\section{Dependent Variables (DV):}

Global Environmental Performance (GEP) is measured by the Environmental Impact Score (EIS). The score is provided by Trucost (Trucost, 2010), the world's most comprehensive data provider on corporate environmental impacts for the last 10 years (Cho, Guidry, Hageman, \& Patten, 2012; McGinn, 2009; Dawkins \& Fraas, 2011). This data is a comprehensive, quantitative, and standardized measurement made up of more than 700 metrics to assess the total environmental impacts of a corporation's global operations (90 percent of total score) and disclosure of those impacts (10 percent of total score), including emissions of nine key greenhouse gases, water use, solid-waste disposal, and emissions that contribute to acid rain and smog. The score is an assessment of the company's actual environmental footprint. The data for each of these measures comes from publically disclosed firm environmental data like the EPA Toxics Release Inventory. Trucost used a "proprietary economic input-output model to calculate direct-company and supply-chain impacts in where data is unavailable" (http://www.thedailybeast.com/newsweek/2010/10/18/green-rankings-2010-full-

methodology.html). It is published on a scale from 100 (highest performing) to one (lowest performing). The data is available for 2009, 2010, and 2011. Because the methods have slightly changed from year to year and because the scores provided are not absolute scores but are determined in comparison to the set of firms in the dataset of that year, accurate year to year comparisons are challenging to achieve. For my analyses, I use the Y2010 data. For more details on this variable, please refer to Appendix 3. 
Environmental Corporate Reputation: CorporateRegister.com is the world's largest online directory of social responsibility, sustainability, and environmental reports (Maak, 2008; van den Brink \& van der Woerd, 2004). In 2010, they conducted a survey on environmental reputation among their subscribers for Newsweek magazine's Green Rankings of Fortune 500 firms (Guidry \& Pattern, 2010; McGinn, 2009). This online survey was sent to 14,921 validated users who are professionals, academics, and other environmental experts who subscribe to CorporateRegister.com, including CEOs of companies being rated. Respondents were asked to rate a random sample of 15 companies on a sliding scale (100 to one) from "leader" to "laggard" on three key green areas: environmental performance, commitment, and communications. Each company environmental reputation score was the average of these three components. CorporateRegister.com hosted the survey on its website for a total data collection period of six weeks from July to August 2010 with a response rate of 12\% (Green Ranking Methodology, 2010). I used the data from the 2010 administration of this survey to measure environmental reputation in this study, in line with prior studies that have also used this measure of environmental reputation (e.g., Guidry \& Patten, 2010; Cho, Guidry, Hageman, \& Patten, 2012). Similar to GEP, this variables is also published on a scale from 100 (highest performing) to one (lowest performing). The scores provided are not absolute scores but are determined in comparison to the set of firms in the 2010 dataset. Newsweek uses this same measure to calculate their annual Green Rankings Scores of US and Global Fortune 500 firms. This variable has a normal distribution as depicted by figure 5 . 
FIGURE 5: Environmental Reputation Frequency Distribution

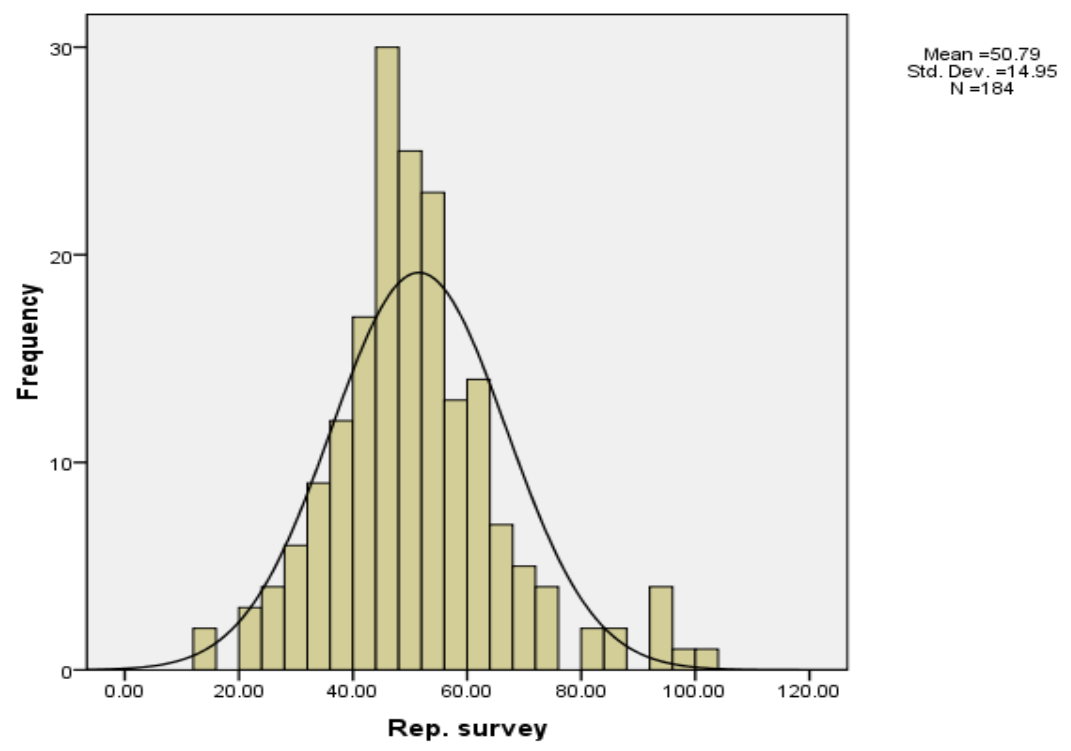

\section{Independent Variables}

Verbal Environmental Commitment (VC) (H1): This construct is measured by capturing (1) mission statements, (2) environmental intent and (3) environmental reporting. Each of these is described in detail below.

David (1989) explains that a firm's mission statement is "an enduring statement of purpose that distinguishes one organization from similar enterprises". It is through the mission statement that firms communicate what is important to internal and external stakeholders (Mitchell, 2002). Thus, the first part of our measurement of verbal commitment to environmental issues is captured by examining the sample companies' mission statements (Dechant \& Altman, 1994; Amato \& Amato, 2002). For each company, the stated mission and/or vision statements were collected as articulated in the year 2008. Those that mention Global Environment or Environment in their mission statement are coded as "1"; otherwise 
they are coded " 0 ", indicating that this company does have at least a verbal commitment towards environmental issues. The data sources for these mission statements were found at www.company-statements-slogans.info/index.htm (King, Case, \& Premo, 2010), www.missionstatements.com/company_mission_statements.html, as well as the companies' main websites (Sattari, Pitt, \& Caruana, 2011). To analyze the mission statements, each statement was content analyzed for key related words and the context in which they were used. It was important to read each statement in order to accurately get a sense of the context in which these key words were used; therefore I did not rely only on word count. For example, it was not enough that the word "environment" was found in the mission/vision statement, but the researcher made sure it referred to the "natural environment" and not "work environment", which would not have been captured if only the existence of key words were examined. As another example, while the word "sustainable" often refers to practices that are in line with environmental and community development, some firms used the word differently to refer to "sustainable sales growth", and were therefore coded as " 0 ".

I started with the main sample of 184 manufacturing US Fortune 500 firms. Below are the analysis results for 148 Fortune 500 firms' mission/vision statements (36 firms did not list their mission statement). While previous studies focused on only top 50 or 100 Fortune 500 firms (Sattari, Pitt, \& Caruana, 2011), this study is a comprehensive examination of a sample of mission statements of 148 Fortune 500 manufacturing US firms.

From the analysis of these statements, I saw that firms can either mention the environment as a stakeholder or mention their practices towards the environment; hence, the content key 
word coding of " 1 " was marked when (1) the environment was mentioned as a stakeholder, which was referred to when companies mentioned: Environment, planet, earth, communities (King, Case, \& Premo, 2010) and/or (2) when firm environmental compliance practices were mentioned designated by key words like: socially responsibility, sustainability, citizenship, business ethical conduct.

Interestingly, my results revealed the existence of three key types/groups of mission statements. The (1) first group are those that identified the environment as a significant stakeholder or made specific mention of environmental compliance/conscious firm behaviors. The second (2) group of mission statements were very general using words like "improve lives of everyone" without specifically mentioning the environment or the communities they operate in. The third group of mission statements were those that had a very narrow mission which focused on their core business function and maximizing performance in that function, without necessarily mentioning a bigger goal or mission of their firm. For the purpose of my upcoming quantitative analysis, I coded all those that would fall under group 1 as " 1 ". The remaining groups 2 and 3 both received a code of "0". Out of 148 firms that were coded in this analysis, only 43 firms received the code of 1 , reflecting a frequency of $29 \%$ of my sample.

Most of the statements focused on maximizing shareholders wealth, with $29 \%$ of my sample mentioning responsibilities to the environment or communities they operated within. Although one can argue that companies may also be environmentally committed even though they do not mention this in their mission statement, chances are those that do mention these 
words in their mission statement are likely to have a greater commitment to environmental concerns or at least to communicating to their stakeholders that they do, regardless of whether they act upon this consciously or not. While some firms use general statements like "improve the lives of our customers", these were coded with a "0", because again, they did not make specific reference to the environment or the communities they operate within. All those coded with "1" mentioned the words shown above in the proper context of sustainable business practices that reflected social responsibility and environmental committed practices. While most mentioned key stakeholders of customers, shareholders, and investors, only those that coded 1 reflected the environment and community as a key stakeholder whom they specifically mentioned in their company mission statement. Others had a very narrow mission of being the best at what they do within their industry, but again did not reflect the companies seeing their missions in relation to the community, environment, or the planet. Nor did these companies mention their practices in relation to this significant stakeholder. Table 2 illustrates the sample of mission statements that can be characterized under the three types discussed above. Appendix 2 provides a listing for all mission statements of firms in the sample. 
TABLE 2: Summary of Mission Statements Types

\begin{tabular}{|c|c|c|}
\hline Generalist & Specific Green Commitment & Narrow Business Focused \\
\hline $\begin{array}{c}\text { "Our company's mission is to } \\
\text { extend and enhance human life } \\
\text { by providing the highest } \\
\text { quality biopharmaceutical } \\
\text { products" }\end{array}$ & $\begin{array}{l}\text { "We are dedicated to making a } \\
\text { difference in the lives of the patients } \\
\text { we serve by creating new therapies } \\
\text { for serious unmet medical needs. } \\
\text { But our commitment to improving } \\
\text { lives doesn't stop with patients. We } \\
\text { strive to employ the same innovative } \\
\text { spirit we use in developing new } \\
\text { therapies to serve the communities } \\
\text { in which we live and work and to } \\
\text { protect our planet's resources by } \\
\text { reducing our impact on the } \\
\text { environment". }\end{array}$ & $\begin{array}{l}\text { "To be the premier provider to } \\
\text { beverage, food and aerospace and } \\
\text { technologies customers of the } \\
\text { products and services that we offer } \\
\text { as we aggressively manage our } \\
\text { business, and to explore and pursue } \\
\text { acquisitions, divestitures, strategic } \\
\text { alliances and other changes that } \\
\text { would benefit Ball's shareholders." }\end{array}$ \\
\hline
\end{tabular}

For the empirical analysis, the dichotomous variable for verbal commitment is used in the regression analysis.

In addition to the mission statements, data was collected from the Pacific Sustainability Index (PSI) (Morhardt, 2010) produced by Roberts Environmental Center (REC), which has been tracking firm's environmental related transparency behavior for a decade. The PSI data is accessible on http://www.roberts.cmc.edu/currentsectordata.asp. This index is based on the analysis of companies' websites and environmental reports. I specifically collected the data under their "environmental intent" and "environmental reporting" components of the index, which reviews firms' websites to score the company using a base scoring sheet. Because the DV was collected in 2010, data collected ranged in years from 2008-2010.

The environmental intent score, the second component of our verbal commitment measure, is based on components of accountability, management, policy, and vision elements to arrive 
at firms' involvement in the general environment "whereby intent topics are each worth 2 points; 1 point for a discussion of intentions, vision, or plans, and a 1 point for evidence of specific actions taken to implement them" (http://www.roberts.cmc.edu/). Note that the second part of this score did not evaluate the effectiveness of these actions or whether they were fully completed, but solely whether evidence existed that the company was implementing their plans as a signal of potential future completion and performance. The "environmental intent" score for each company is based on what the company scored as a percentage of the highest scoring firm in its sector.

Environmental reporting, the third component of the verbal commitment variable, measures the degree to which a firm actually reports environmental performance data which can be qualitative or quantitative on their websites related to any of these key areas: emissions to air, energy, management, material usage, products, recycling, waste and water. In REC's methodology report, the detailed description of how each element is scored is described as "for quantitative topics, one point is available for a discussion, one point for putting the information into perspective (i.e. awards, industry standards, competitor performance, etc., or if the raw data are normalized by dividing by revenue, number of employees, number of widgets produced, etc.), one point for the presence of an explicit numerical goal, one point for numerical data from a single year, and one point for similar data from a previous year. For qualitative topics, there are three criteria summed up to five points: 1.67 points for discussion, 1.67 points for initiatives or actions, and 1.67 points for perspective". As with the previously described environmental intent score, this score is not meant to capture actual environmental performance, but solely whether a firm verbally reports environmental 
information regarding its activities (regardless of the degree to which it achieved them). It is recognized, however, that firms may be more likely to report activities when they perform them well, which is a potential limitation of the measure. The final "environmental reporting" score for each company is based on what the company scored as a percentage of the highest scoring firm in its sector.

To calculate each firm's verbal environmental commitment, the scores for mission statement, environmental intent, and reporting were each first standardized. Because each of these variables is on a separate scale, it was important that they are translated to $\mathrm{z}$ scores. This allows each variable to have equal weight in the analysis. To compute this variable, the three variables were then added to make up a firm's verbal environmental commitment.

Green Policy Management (H2) is measured by the "Green Policy Score" developed by MSCI ESG Research, which specializes in rating companies (http://www.msci.com/about/) on environmental, social and governance indicators. This data is provided by the same company that offered the KLD (Kinder, Lydenberg, and Domini) Global Socrates database over the past 20 years, except now they are called MSCI ESG as a result of the merger between MSCI and RiskMetrics Group. The green policy score is derived from the KLD data which has been used by a number of management scholars (Berrone \& Gomez-Mejia, 2009; Reid \& Toffel, 2009; Schendler \& Toffel, 2011; Dawkins \& Fraas, 2010) and is described as the "best available" rating tool (Waddock, 2003: 369). The score for each company provides an "assessment of how a company manages its environmental footprint" (Green Ranking 
Methodology, 2010). It is made up of more than 70 individual indicators which are summarized under the following subcomponents:

- Management of Environmental Issues

- Climate Change Policies

- Pollution Policies

- Product Impact

- Environmental Stewardship

The green management policy score of each company is the weighted average of the five sub-components and the weights are industry specific. That is, to account for industry differences, MSCI weights each of these sub-components differently in accordance to their industry; i.e. a mining company will have its green policy subcomponents weighted differently than a food and beverage company. (http://www.thedailybeast.com/newsweek/2010/10/18/green-rankings-2010-fullmethodology.html). The individual scores for these subcomponents are not publically released by MSCI- ESG.

Some items of the Green Policy Score actually captured some level of environmental performance related to climate and pollution components. To address the potential for overlap with what is being captured by the GEP variable, the suspected items were all removed by the data providers (MSCI ESG). For more details on this variable and for a listing of the specific items removed, please refer to Appendix 3. 
Institutional Network Diversity (H7) is measured by the degree of variation (coefficient of variation) in selected environmental elements of an MNC's institutional context. For each subsidiary host market, a number of institutional variables related to the environment were collected and captured at the host market level from multiple data sources. These are summarized in the following Table 3.

TABLE 3: Environmental Institutional Items

\begin{tabular}{|c|c|c|}
\hline Variable name & Data Source & Variable Description \\
\hline Rule of Law & $\begin{array}{l}\text { Corporate Governance Indicators (2007 } \\
\text { CGI: } \\
\text { http://www.developmentdata.org/gover } \\
\text { nance.htm) } \\
\begin{array}{l}\text { Note: } 2007 \text { is the latest year for this } \\
\text { database }\end{array}\end{array}$ & $\begin{array}{l}\text { "capturing perceptions of the extent to which agents } \\
\text { have confidence in and abide by the rules of society, } \\
\text { and in particular the quality of contract enforcement, } \\
\text { property rights, the police, and the courts, as well as } \\
\text { the likelihood of crime and violence". } \\
\text { http://papers.ssrn.com/sol3/papers.cfm?abstract id=1 } \\
682130\end{array}$ \\
\hline $\begin{array}{c}\text { Regulatory } \\
\text { Quality }\end{array}$ & $\begin{array}{l}\text { Corporate Governance Indicators ( } 2007 \\
\text { CGI: } \\
\text { http://www.developmentdata.org/gover } \\
\text { nance.htm) } \\
\begin{array}{l}\text { Note: } 2007 \text { is the latest year for this } \\
\text { database }\end{array}\end{array}$ & $\begin{array}{l}\text { "capturing perceptions of the ability of the } \\
\text { government to formulate and implement sound } \\
\text { policies and regulations that permit and promote } \\
\text { private sector development." } \\
\text { http://papers.ssrn.com/sol3/papers.cfm?abstract_id=1 } \\
682130\end{array}$ \\
\hline $\begin{array}{l}\text { Stringency of } \\
\text { Environmental } \\
\text { regulations }\end{array}$ & $\begin{array}{l}\text { World Competiveness Report (2007 } \\
\text { WCR: } \\
\text { http://www.weforum.org/issues/global- } \\
\text { competitiveness): }\end{array}$ & $\begin{array}{l}\text { How stringent is your country's environmental } \\
\text { regulations? } 1=\text { lax compared with that of most } \\
\text { countries, } 7=\text { among the world's most stringent }\end{array}$ \\
\hline $\begin{array}{l}\text { Clarity and } \\
\text { stability of } \\
\text { environmental } \\
\text { regulations }\end{array}$ & $\begin{array}{l}\text { World Competiveness Report (2007 } \\
\text { WCR: } \\
\text { http://www.weforum.org/issues/global- } \\
\text { competitiveness): }\end{array}$ & $\begin{array}{l}\text { Environmental regulations in your country are } 1= \\
\text { confusing and enforced erratically, } 7=\text { stable and } \\
\text { enforced consistently and fairly }\end{array}$ \\
\hline $\begin{array}{l}\text { Environmental } \\
\text { Performance } \\
\text { Index (EPI) }\end{array}$ & $\begin{array}{l}\text { Environmental Performance Index } \\
\text { (EPI) scores provided by Yale Center } \\
\text { for Environmental Law and Policy and } \\
\text { the Center for International Earth } \\
\text { Science Information Network in } 2010 \\
\text { (http://epi.yale.edu/Countries). }\end{array}$ & $\begin{array}{l}\text { Collected host markets' environmental performance } \\
\text { (Christmann, 2004) . This variable "provide(s) a } \\
\text { gauge at a national government scale of how close } \\
\text { countries are to established environmental policy } \\
\text { goals" (Environmental performance index Report: } \\
\text { 2010: 6). This data is available for } 163 \text { countries. }\end{array}$ \\
\hline
\end{tabular}




\title{
Calculation of Environmental Institutional Network Diversity Score:
}

After identifying the locations of all subsidiaries in an MNC network, each subsidiary is given a score based on its host country for each of the above country variables. Because the unit of analysis is the MNC network, it was important to have one score for each MNC. To calculate this, for each variable collected for a given MNC across its subsidiaries, the (a) mean, and (b) standard deviation were calculated. Based on the scores for these two numbers, the (c) ratio of standard deviation to mean (known as coefficient of variation/COV) was then computed. This variable was then labeled as "Network diversity", followed by the institutional variable being measured. The variables calculated are shown below.

\author{
Network Diversity- EPI(COV) \\ Network Diversity-Rule of law 2007 (COV) \\ Network Diversity- Regulatory Quality 2007 (COV) \\ Network Diversity Stringency of Environmental Regulations-(COV) \\ Network Diversity Clarity and stability of Environmental Regulations- WCR 2006/2007 (COV)
}

Principal component factor analysis was conducted on these variables which load strongly on one factor as shown in table 4. This was repeated using "principle-axis factoring" extraction to conduct exploratory factor analysis (EFA) using promax rotation, and once again, the variables loaded on a single factor as per the below scree plot in figure 6 . 
TABLE 4: Factor Analysis of Environmental Institutional Diversity

\section{Component Matrix ${ }^{\mathrm{a}}$}

\begin{tabular}{|l|c|}
\hline & Component \\
\cline { 2 - 2 } & 1 \\
\hline Rule of law 2007 (COV) & .796 \\
Regulatory Quality 2007 (COV) & .877 \\
Stringency of Environmental regulations (WCR) (COV) & .921 \\
Clarity and stability of Environmental Regulations (WCR) (COV) & .929 \\
EPI (COV) & .680 \\
\hline
\end{tabular}

Extraction Method: Principal Component Analysis.

a. 1 components extracted.

Total Variance Explained

\begin{tabular}{|c|c|c|c|c|c|c|}
\hline \multirow{2}{*}{ Component } & \multicolumn{3}{|c|}{ Initial Eigenvalues } & \multicolumn{3}{|c|}{ Extraction Sums of Squared Loadings } \\
\cline { 2 - 7 } & Total & \% of Variance & Cumulative \% & Total & \% of Variance & Cumulative \% \\
\hline 1 & 3.577 & 71.544 & 71.544 & 3.577 & 71.544 & 71.544 \\
2 & .815 & 16.290 & 87.834 & & & \\
3 & .427 & 8.543 & 96.377 & & & \\
4 & .143 & 2.858 & 99.236 & & & \\
5 & .038 & .764 & 100.000 & & & \\
\hline
\end{tabular}

Extraction Method: Principal Component Analysis.

Figure 6: EFA Scree Plot

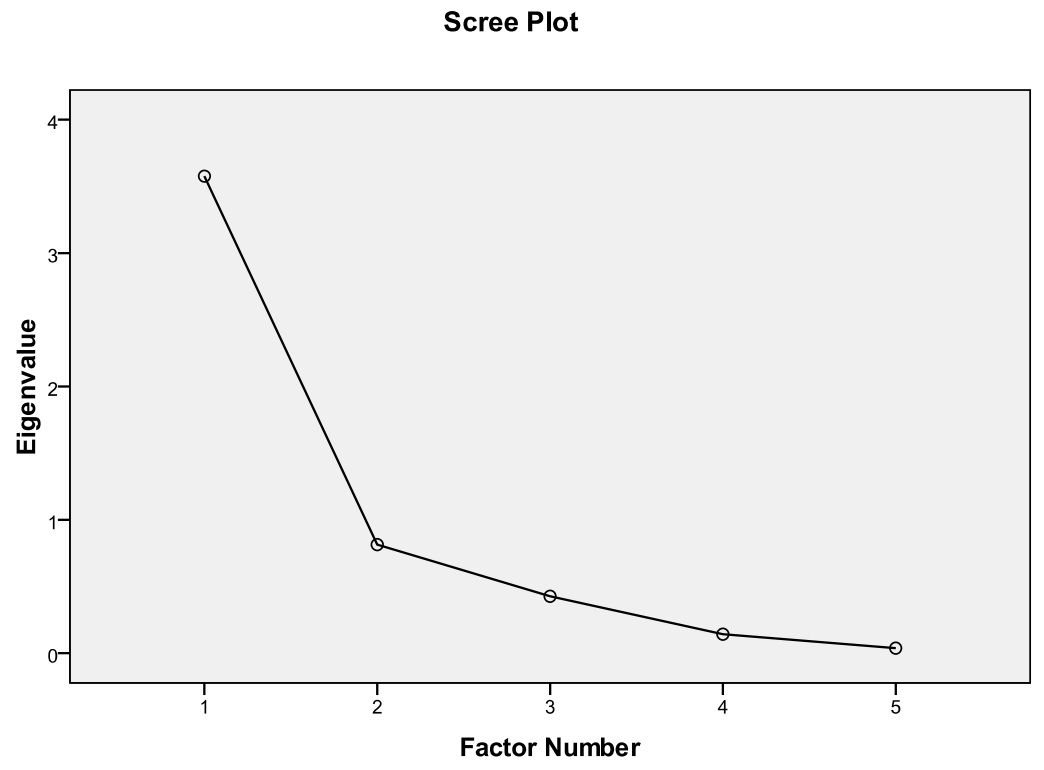


Furthermore, a reliability test was conducted. The Cronbach's alpha for the five items is .636 as shown in table 5. The examination of the item statistics shows that with the exception of a slight increase in Cronbach's alpha when EPI (COV) is removed, the items hold well together.

TABLE 5: Reliability Analysis Institutional Diversity Items

Reliability Statistics

\begin{tabular}{|c|c|c|c|c|c|}
\hline Cronbach's Alpha & \multicolumn{3}{|c|}{ Cronbach's Alpha Based on Standardized Items } & \multicolumn{2}{|c|}{$\mathrm{N}$ of Items } \\
\hline .636 & \multicolumn{3}{|c|}{.897} & \multicolumn{2}{|c|}{5} \\
\hline \multicolumn{6}{|c|}{ Item-Total Statistics } \\
\hline & $\begin{array}{l}\text { Scale Mean if } \\
\text { Item Deleted }\end{array}$ & $\begin{array}{c}\text { Scale Variance if } \\
\text { Item Deleted }\end{array}$ & $\begin{array}{l}\text { Corrected Item- } \\
\text { Total Correlation }\end{array}$ & $\begin{array}{l}\text { Squared } \\
\text { Multiple } \\
\text { Correlation }\end{array}$ & $\begin{array}{l}\text { Cronbach's } \\
\text { Alpha if Item } \\
\text { Deleted }\end{array}$ \\
\hline EPICOV EPI (COV) & 2.12 & 1.120 & .407 & .467 & .659 \\
\hline Rule of law 2007 (COV) & 1.23 & .222 & .809 & .721 & .524 \\
\hline $\begin{array}{l}\text { Regulatory Quality } 2007 \\
\text { (COV) }\end{array}$ & 1.51 & .570 & .863 & .768 & .298 \\
\hline $\begin{array}{l}\text { Stringency of Environmental } \\
\text { regulations (WCR) (COV) }\end{array}$ & 2.06 & 1.059 & .683 & .927 & .624 \\
\hline $\begin{array}{l}\text { Clarity and stability of } \\
\text { Environmental Regulations } \\
\text { (WCR) (COV) }\end{array}$ & 2.07 & 1.069 & .731 & .926 & .629 \\
\hline
\end{tabular}

Based on the results of above analysis, the five variables were added together to constitute "Environmental Institutional Diversity". Another version of this variable was calculated by taking the mean score for the five items, instead of adding them, to test if the computation of the variable had an impact. The correlation matrix was the same for both variable versions, indicating both computations yielded the same results.

Dispersion (H8): It is important to account for how the distances between headquarters and subsidiaries impact whether polices translate to performance. In addition to this, it is also 
important to account for how the variations in these distances can also effect management and implementation of policies. For example, a firm that has a majority of units within similar distances from the HQ is likely to face fewer challenges than a firm that has to manage a network consisting of a mix of very close and very distant units. To illustrate this point, the below figures are used to distinguish the difference between what geographic distance captures vs. what geographic distance variation captures. This is further explained to show that both are likely to impact the ability of a HQ to manage and align operations within the subsidiary network. Figure 7 provides a characterization of geographic distance as the distance between HQ and subsidiary. This is the standard way of measuring geographic distance in the IB literature (Markides, 1995, Ghemawat, 2001, Mauri, 2009)

Figure 7: Geographic Distance

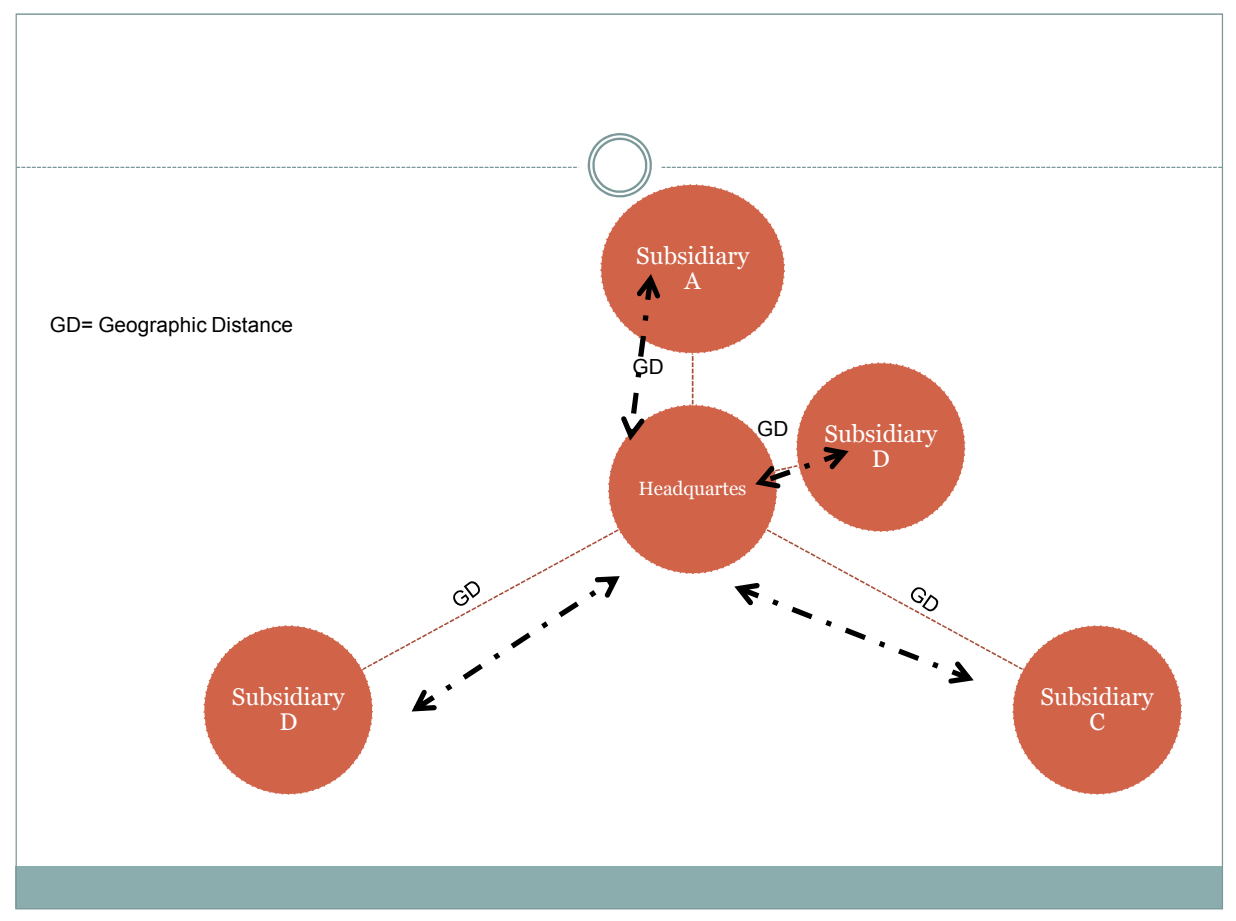


Figures 9, 10, and 11 illustrate the variation that can occur in geographic distances representing the potential configuration of different MNCs. In figure 8, the units are at fairly equal distances from the parent. In figure 9, although the units are at high distances from the parent, the distances are once again fairly equal, allowing the parent to standardize the modes of communication when reaching these units. But in figure 10, there is high variation in the geographic distances between HQ and subsidiaries. Therefore, the firm in figure 10 faces higher challenges because the firm needs to deal with greater variations in distance, which increase complexity. Having high variation in distances reflecting a mix of units being close and others being too far is likely to also increase HQ-subsidiary conflict due to concerns for preferential treatment of the closer units (Bouquet \& Birkinshaw, 2008).

Figure 8

$G D=$ Low Geograph ic Distance Cov

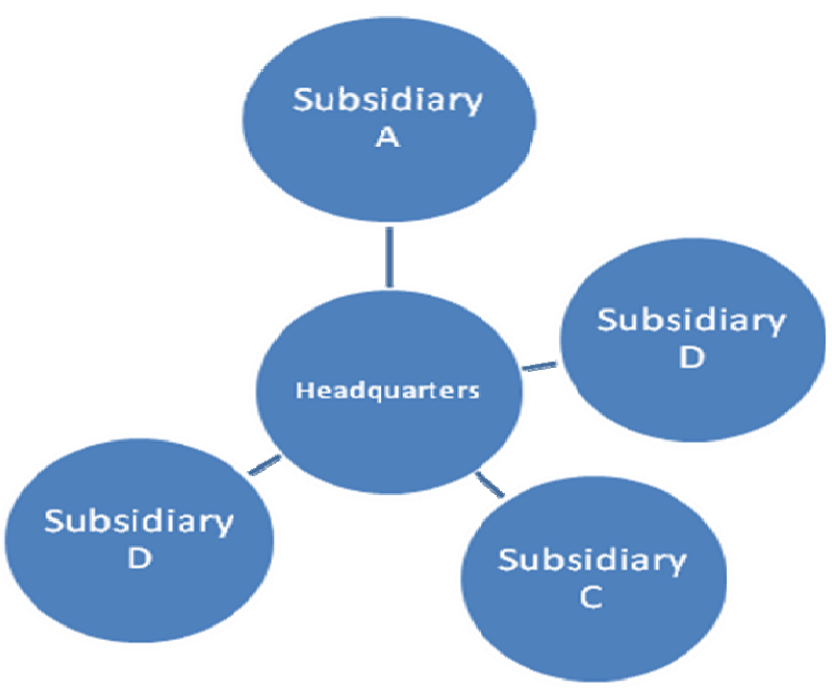


Figure 9
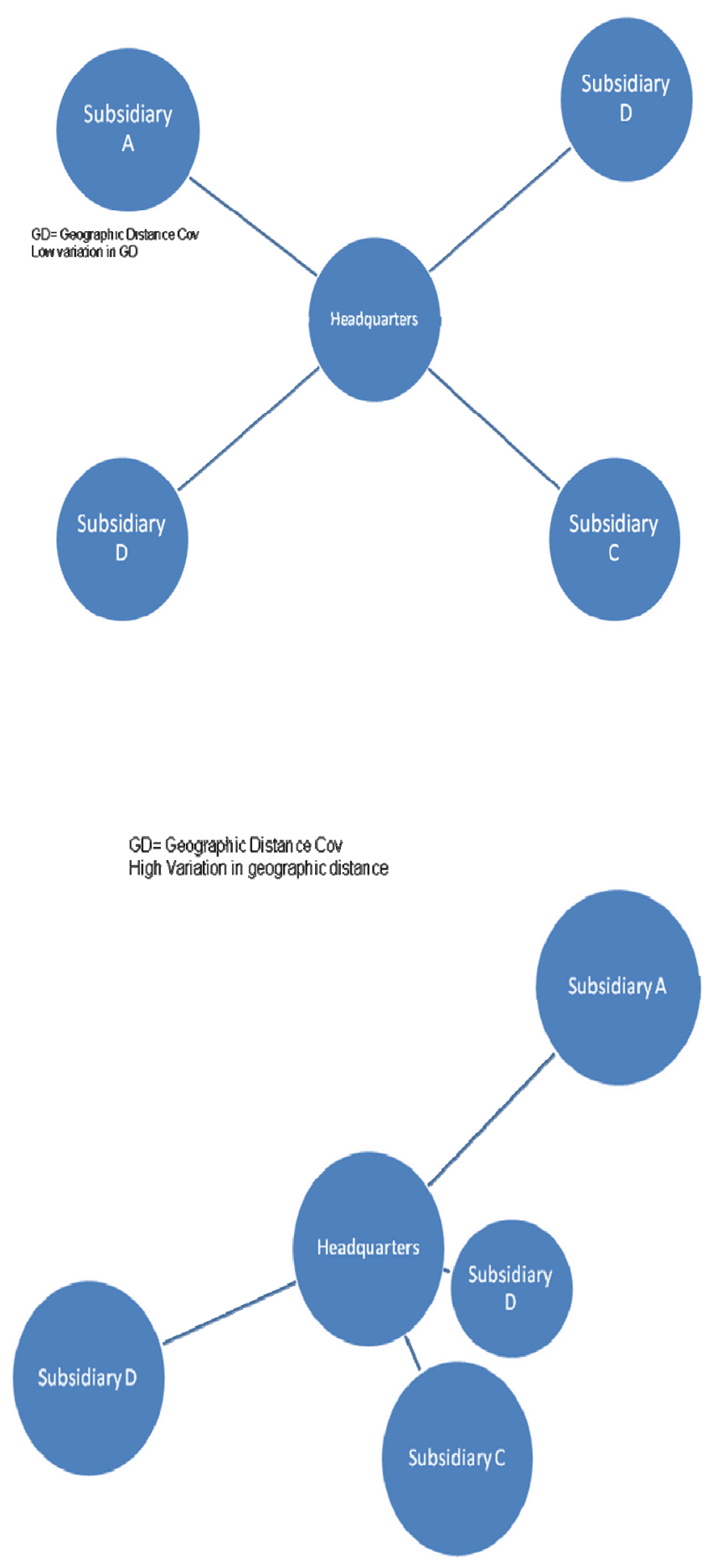

To capture the above relationships, which are likely to impact corporate environmental management, a variable is created that measures the average geographic distance (presented 
in figure 7) between HQ and subsidiaries weighted by the degree of geographic distance variation (illustrated by figures 9,10 , and 11).

To calculate this variable, I first calculate the (1) average physical distance between an MNC's HQ location and the location of its subsidiaries measured in kilometers (Ghemawat, 2001; Markides, 1995; Mauri, 2009). Each network is given one score based on averaging the combination of distances. Another measure is then created which takes into account (2) the degree of variation in the network for such distances measured by calculating the coefficient of variation (COV) of geographic distance (COV) (mean/standard deviation). Both of these two numbers are then standardized and are used to create the "geographic dispersion" variable by multiplying them, arriving at a measure of geographic distance that is weighted by degree of geographic distance variation (COV).

Density (H9) is measured by the number of foreign subsidiaries in the network which share the same parent firm in the US. The higher the number of foreign subsidiaries an MNC has, the greater the density of that MNC network (Tallman \& Li, 1996; Tsai, 2000a, 2001b; Varadarajan \& Ramanujam, 1987). This is similar to the definition of network "breadth" (Pantzalis, Simkins, \& Laux, 2001) and that of “within density”, (Ghoshal \& Bartlett, 2005).

\section{Control Variables}

It is important to control for company size, measured by the natural log of total number of employees (2010) (Christmann, 2004; Christmann \& Taylor, 2006), since size may impact the environmental conduct of the firm (Aragon-Correa, 1998). In addition, we need to control 
for MNC financial performance, measured by return on sales (ROS) as reported by parent company financial statements accessed from Compustat for year 2010. Furthermore, we control for industry sector by creating dichotomous variables for each manufacturing sector, which was categorized by SIC codes in Table 6 below. All dummy variables were included in the regression analysis, with Petroleum and Chemical industry firms serving as the excluded dummy (SIC codes 2800-2900).

TABLE 6: List of Sector Dichotomous Variables

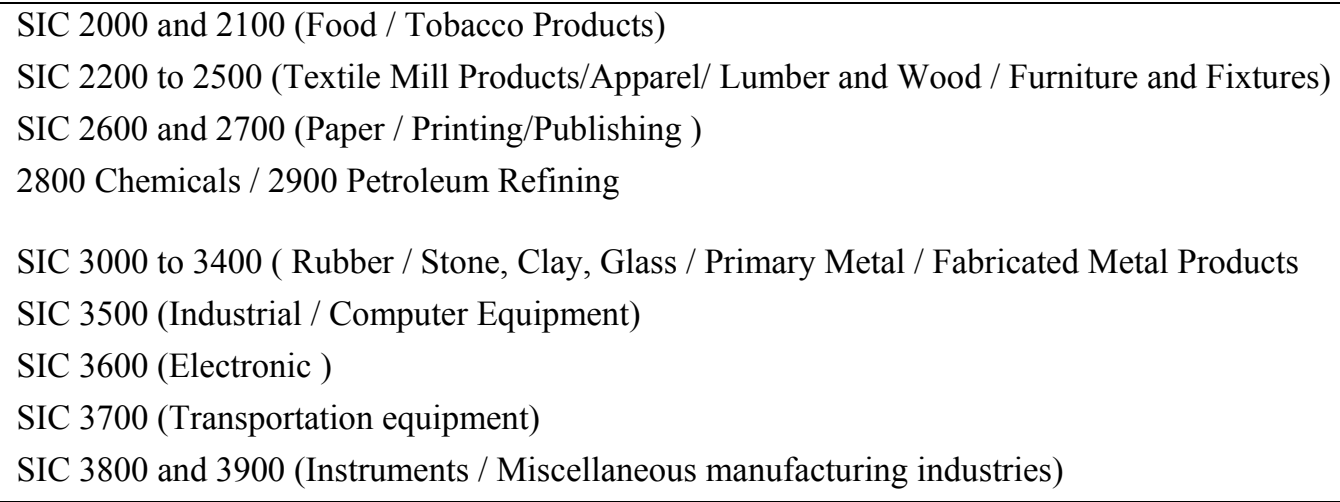

The below tables 7, 7a, and 7b show a summary of GEP, Green Policy Management, and Environmental Reputation Scores data by manufacturing sector. Preliminary data analysis suggested that both GEP and Green Policy Management significantly vary by industry sector. Hence, these statistics indicate that industry needs to be accounted for in the regression analyses. On the other hand, Environmental reputation (shown in table 7b) was not found to significantly vary by sector type. 
TABLE 7: ANOVA Sector Effects by GEP

Report

Envtl.Impact Envtl. Impact $Y 2010$
\begin{tabular}{|l|c|r|r|}
\hline IndustrvType & Mean & N & Std. Deviation \\
\hline 1.00 SIC2000and2100 & 10.1236 & 25 & 6.03580 \\
2.00 SIC2200to2500 & 44.3629 & 7 & 34.08755 \\
3.00 SIC2600and2700 & 22.2360 & 10 & 15.18640 \\
4.00 SIC2800and2900 & 42.8079 & 39 & 24.78460 \\
5.00 SIC3000to3400 & 34.6993 & 15 & 29.56479 \\
6.00 SIC3500 & 56.7132 & 28 & 24.38559 \\
7.00 SIC3600 & 59.2764 & 22 & 26.83165 \\
8.00 SIC3700 & 45.1972 & 18 & 23.47985 \\
9.00 SIC3800AND3900 & 64.0430 & 20 & 25.84029 \\
Total & 43.2742 & 184 & 28.73835 \\
\hline
\end{tabular}

Tests of Between-Subjects Effects

Dependent Variable:Envtl.Impact Envtl. Impact Y 2010

Dependent Variable:Envtl.Impact Envtl. Impact Y 2010
\begin{tabular}{|l|r|r|r|r|r|}
\hline Source & \multicolumn{1}{c|}{$\begin{array}{c}\text { Type III Sum } \\
\text { of Squares }\end{array}$} & df & Mean Square & \multicolumn{1}{c|}{ F } & \multicolumn{1}{|c|}{ Sig. } \\
\hline Corrected Model & $52403.763^{\mathrm{a}}$ & 8 & 6550.470 & 11.610 & .000 \\
Intercept & 256259.662 & 1 & 256259.662 & 454.202 & .000 \\
IndustryType & 52403.763 & 8 & 6550.470 & 11.610 & .000 \\
Error & 98734.598 & 175 & 564.198 & & \\
Total & 495706.893 & 184 & & & \\
Corrected Total & 151138.361 & 183 & & & \\
\hline
\end{tabular}

a. R Squared $=.347$ (Adjusted R Squared $=.317)$

TABLE 7a: ANOVA Sector Effects by Green Policy

Report

GreenPolicies Green Policies Y 2010

\begin{tabular}{|l|c|r|r|}
\hline IndustrvTve & Mean & $\mathrm{N}$ & Std. Deviation \\
\hline 1.00 SIC2000and2100 & 47.7092 & 25 & 21.56111 \\
2.00 SIC2200to2500 & 40.5929 & 7 & 25.37077 \\
3.00 SIC2600and2700 & 55.1340 & 10 & 13.20692 \\
4.00 SIC2800and2900 & 54.1597 & 39 & 21.77829 \\
5.00 SIC3000to3400 & 43.4767 & 15 & 18.80142 \\
6.00 SIC3500 & 43.9064 & 28 & 26.21594 \\
7.00 SIC3600 & 49.8536 & 22 & 22.76288 \\
8.00 SIC3700 & 33.6256 & 18 & 18.61605 \\
9.00 SIC3800AND3900 & 40.6585 & 20 & 19.09627 \\
Total & 46.3978 & 184 & 22.09891 \\
\hline
\end{tabular}


Tests of Between-Subjects Effects

Dependent Variable:GreenPolicies Green Policies Y 2010

\begin{tabular}{|l|r|r|r|r|r|}
\hline Source & \multicolumn{1}{|c|}{$\begin{array}{c}\text { Type III Sum } \\
\text { of Squares }\end{array}$} & df & Mean Square & \multicolumn{1}{c|}{ F } & \multicolumn{1}{c|}{ Sig. } \\
\hline Corrected Model & $7551.417^{a}$ & 8 & 943.927 & 2.019 & .047 \\
Intercept & 297881.461 & 1 & 297881.461 & 637.130 & .000 \\
IndustryType & 7551.417 & 8 & 943.927 & 2.019 & .047 \\
Error & 81818.823 & 175 & 467.536 & & \\
Total & 485476.833 & 184 & & & \\
Corrected Total & 89370.240 & 183 & & & \\
\hline
\end{tabular}

a. R Squared $=.084$ (Adjusted R Squared $=.043$ ) 
TABLE 7b: ANOVA Sector Effects by Reputation

Report

Rep.survey Rep. survey
\begin{tabular}{|l|c|r|r|}
\hline IndustrvType & Mean & N & Std. Deviation \\
\hline 1.00 SIC2000and2100 & 44.3564 & 25 & 20.59124 \\
2.00 SIC2200to2500 & 47.4300 & 7 & 8.65075 \\
3.00 SIC2600and2700 & 59.2990 & 10 & 14.83260 \\
4.00 SIC2800and2900 & 53.1564 & 39 & 15.10273 \\
5.00 SIC3000to3400 & 51.0393 & 15 & 16.94957 \\
6.00 SIC3500 & 53.7621 & 28 & 15.35879 \\
7.00 SIC3600 & 50.2332 & 22 & 13.33751 \\
8.00 SIC3700 & 49.4378 & 18 & 10.07767 \\
9.00 SIC3800AND3900 & 48.6565 & 20 & 8.40498 \\
Total & 50.7939 & 184 & 14.95044 \\
\hline
\end{tabular}

Tests of Between-Subjects Effects

Dependent Variable:Rep.survey Rep. survey

\begin{tabular}{|l|r|r|r|r|r|}
\hline Source & \multicolumn{1}{|c|}{$\begin{array}{c}\text { Type III Sum } \\
\text { of Squares }\end{array}$} & df & Mean Square & \multicolumn{1}{c|}{ F } & \multicolumn{1}{c|}{ Sig. } \\
\hline Corrected Model & $2435.276^{\mathrm{a}}$ & 8 & 304.410 & 1.385 & .206 \\
Intercept & 372294.024 & 1 & 372294.024 & 1693.649 & .000 \\
IndustryType & 2435.276 & 8 & 304.410 & 1.385 & .206 \\
Error & 38468.106 & 175 & 219.818 & & \\
Total & 515627.357 & 184 & & & \\
Corrected Total & 40903.382 & 183 & & & \\
\hline
\end{tabular}

a. R Squared $=.060($ Adjusted R Squared $=.017)$

\section{Statistical Analysis}

The general approach to testing the hypotheses in this dissertation was one where each set of hypotheses predicting a different dependent variable was tested in a separate set of linear regression models. While the study draws from concepts of complexity theory, multiple regression analysis is used, given that the DVs are continuous (Mauri, 2009; Cho \& Lee, 2004). While it is important to note the potential critique of using linear parsimonious models to conceptualize complex organizations (Casti, 1994), modern complexity theory would 
argue that complex systems can be reduced to simple relationships (Simon, 1996; Cohen \& Stewart, 1994), which is believed to be the task of the researcher. Anderson (1999: 217) explains that "modern complexity theory suggests that some systems with many interactions among highly differentiated parts can produce surprisingly simple, predictable behavior, while others generate behavior that is impossible to forecast, though they feature simple laws and few actors". This study builds on scholarly works that have also used OLS regression to analyze networks (Mauri, 2009; Cho \& Lee, 2004). It is also very common for scholars to use regression to examine interaction effects of observed variables (Jaccard \& Turrisi, 2003). Although, SEM provides insights into examining the simultaneous impact of the independent variables on the DV, the chosen main analytical approach is more in line with the "peel the onion" research approach and theoretical arguments of this study which sought to break the complexity of the MNC's CEM process into simple testable relationships.

Testing the various hypothesized relationships separately makes the assumption that the errors across variables and equations are uncorrelated. With respect to errors associated with data collection method, the greatest chance for correlated errors seems to occur when the same instrument or method is used to collect both independent and dependent variables. This is not the case here since each variable is collected from an independent data provider. Correlated errors also may be associated with missing variables that affect multiple dependent variables in the models. For example, if the variable Company Size had been eliminated as a control variable, this could cause problems in interpreting the study results since this variable has a significant impact in all of the subsequently reported dissertation models. While Company Size was included within the dissertation models, it is recognized 
that other variables like this may exist. Additionally, the possibility exists that errors may be correlated due properties inherent in the variables themselves (e.g. a variable with a truncated distribution). The possibility of correlated errors is recognized as a limitation of the study.

To minimize multicollinearity, the direct effects variables were standardized and centered prior to creating the moderating effects (Aiken \& West, 1991). Collinearity diagnostics were conducted and variance inflation factors (VIFs) examined to determine if multicollinearity is a concern (Netter, Wasserman \& Kutner, 1996). With the exception of one model regression in model 4 and model 5 in table 10a, all VIFs were below 2. The moderating variables created aimed to examine if network features (density, dispersion, and diversity) moderated the relationship between environmental management and GEP. The names of these created moderating variables are shown below.

Green Policy Management X Density

Green Policy Management X Geographic Dispersion

Green Policy Management X “Environmental Institutional Diversity”.

Within Post Hoc analyses, Hierarchal Cluster Analysis was also used to classify firms considering their GEP, green policy management, network dimensions (density, geographic distance, and environmental institutional score). Analysis was performed using the Ward's approach, where the squared Euclidean distances are used to form clusters (Hair \& Black, 2000; Saunders, 1993). The variables were standardized to form z- scores. 


\section{RESULTS}

Table 8 shows the descriptive statistics including the ranges and standard deviations for each of the variables. Table 9 shows the correlations for the main effect variables. The highest correlation found was .46 between firm size (employees) and network density (number of foreign subsidiaries), which is likely to raise concerns for multicollinearity when testing interaction effects. Due to this, variance inflation factors (VIFs) were examined for each model, as noted earlier, and potential issues are detailed below when applicable.

Environmental Verbal Commitment: Hypotheses 1 argued that there is a positive relationship between Verbal Commitment (VC) and GEP. The regression results shown in model 2 of Table 10 support hypothesis $1(\mathrm{p}<.05)$. This indicates that environmental verbal commitment does significantly predict GEP when sector type, firm performance and size are controlled. However when both Green Policy Management and Verbal Commitment are incorporated in the model, only Green Policy Management had a significant positive relationship with GEP.

Hypothesis 2 predicted that Verbal Commitment would predict firm Green Policy Management. The results shown in table 11 support this hypothesis $(\mathrm{p}<.01)$.

Green Policy Management: Hypothesis 3 predicted a positive relationship between firms' Green Policy Management and Global Environmental Performance. This relationship tested in model 2 of Table 10 was found to be positive and significant $(\mathrm{p}<.001)$. Therefore, H3 is 
supported with the model having an adjusted R-Square of .481 with a significant R-Square change.

Environmental Reputation: Table 12 shows the regression results predicting Environmental Reputation. Hypothesis 4 (tested in model 2) predicted a positive relationship between VC and Environmental Reputation, arguing that firms use mission statements to signal to investors and other stakeholder groups what they stand for or plan to do. This hypothesis is supported $(\mathrm{p}<.05)$. Therefore, firms' VC did predict their environmental reputation.

H5 predicted a positive relationship between Green Policy Management and Environmental Reputation. This hypothesis shown in model 3 of table 12 was supported $(p<.001)$. The model has a significant adjusted R-Square of .353 and a significant R-Square change $(\mathrm{p}<.001)$. H6 predicted that GEP would have a positive relationship with Environmental Reputation. This relationship as shown in table 12 , model 4 is supported $(\mathrm{p}<.001)$ with a significant adjusted R-Square of .169 and a significant R-Square change.

Model 5 tests the three variables (VC, GEP and Green Policy Management) together in predicting Environmental Reputation. In this complete model, only the Green Policy Management variable was found to be significant $(\mathrm{p}<.01)$. While GEP and VC were not found significant in the complete model, the model still was significant with an adjusted RSquare of $.409(\mathrm{p}<.001)$ and a significant R-Square change. 
Network Moderation Effects: Table 10a shows the regression results for the network interaction effects. H7 argued that Environmental Institutional Diversity would negatively moderate the relationship between Green Management and GEP. While the relationship was found to be negative as shown in model 3, and in the expected direction, no statistical significance was found. The highest VIF reported was for the interaction term (VIF=1.5). Therefore, $\mathrm{H} 7$ was not supported.

H8 predicted that Geographic Dispersion would negatively moderate the Green Management to GEP relationship. It was also not supported in model 3 of table 10a. The highest VIF reported was for the interaction term $(\mathrm{VIF}=1.5)$.

H9 predicted that Network Density would negatively moderate the relationship between Green Management and GEP. Although the relationship is negative as expected, it is also not significant in model 4 of table 10a. The VIF factor for the interaction term is 14.411 , which is above the allowable cut off of 10 (Neter, Wasserman \& Kutner, 1989). This was expected given the high correlation between Firm Size and Density.

Model 5 of table 10a tested all the interaction terms in the same model. The highest reported VIF factor in this complete model was for Network Density $(\mathrm{VIF}=10.965)$ and for the density network moderation variable $(\mathrm{VIF}=16.661)$; all others were below 10 (Neter, Wasserman \& Kutner, 1989). Only the main effect of Green Policy Management was found to be significant in that model $(\mathrm{p}<.001)$. While the individual interaction effects were found 
not significant, the model itself had an adjusted $\mathrm{R}$-square of .426 with a significant $\mathrm{R}$-square change $(\mathrm{p}<.001)$. 
TABLE 8: Descriptive Statistics

\begin{tabular}{|c|c|c|c|c|c|c|}
\hline $\begin{array}{l}\text { Variable } \\
\text { Number }\end{array}$ & & $\mathrm{N}$ & Minimum & Maximum & Mean & $\begin{array}{c}\text { Std. } \\
\text { Deviation }\end{array}$ \\
\hline 1 & Global Environmental Performance (GEP) & 184 & 1.20 & 99.51 & 43.75 & 29.34 \\
\hline 2 & Environmental Reputation & 184 & 13.71 & 100.00 & 50.79 & 14.95 \\
\hline 3 & Firm Size (log Employees 2010) & 182 & .99 & 5.78 & 3.504 & .868 \\
\hline 4 & Firm Performance (ROS 2010) & 184 & -1.374 & 5.36 & 8.681 & 8.34 \\
\hline 5 & Verbal Commitment & 99 & -3.62 & 4.52 & .343 & 2.199 \\
\hline 6 & Green Policy Management & 184 & 1.00 & 100.00 & 1.88 & 22.33 \\
\hline 7 & Network Environmental Institutional Diversity & 162 & .00 & 1.48 & .447 & .216 \\
\hline 8 & Network Geographic Dispersion & 160 & -3545.60 & 781.43 & -156.07 & 520.16 \\
\hline 9 & Network Density & 164 & 1 & 86 & 2.80 & 21.55 \\
\hline
\end{tabular}


TABLE 9: Correlation Matrix

Correlations

\begin{tabular}{|c|l|c|c|c|c|c|c|c|c|}
\hline & & 1 & 2 & 3 & 4 & 5 & 6 & 7 & 8 \\
\hline 1 & & & & & & & \\
& Plobal Environmental & & & & & & \\
\hline 2 & Environmental Reputation & $.316^{* *}$ & & & & & & \\
\hline 3 & Firm Performance (ROS 2010) & .037 & .074 & & & & & & \\
\hline 4 & Firm Size (Employees 2010) & $.251^{* *}$ & $.421^{* *}$ & $-.146^{*}$ & & & & & \\
\hline 5 & Verbal Commitment & .029 & .299 & .025 & .126 & & & & \\
\hline 6 & Green Policy Management & $.322^{* *}$ & $.552^{* *}$ & .056 & $.368^{* *}$ & $.447^{* *}$ & & & \\
\hline 7 & $\begin{array}{l}\text { Network Environmental } \\
\text { Institutional Diversity }\end{array}$ & -.060 & .029 & -.108 & .112 & .089 & -.005 & & \\
\hline 8 & Network Geographic Dispersion & $.120^{*}$ & .147 & .033 & $.177^{*}$ &.-.124 & .145 & -.082 & \\
\hline 9 & Network Density & .139 & $.318^{* *}$ & -.107 & $.460^{* *}$ & .066 & $.246^{* *}$ & $.286^{* *}$ & $.175^{*}$ \\
\hline
\end{tabular}


TABLE 10: Regression Results: Predicting GEP

\begin{tabular}{|c|c|c|c|c|}
\hline Hypothesis \# & & H1 & H3 & H3 \\
\hline & M1 & $\begin{array}{c}\mathrm{M} 2 \\
\mathrm{~N}=99\end{array}$ & $\begin{array}{c}\text { M2a } \\
\mathrm{N}=182\end{array}$ & $\begin{array}{c}\mathrm{M} 2 \mathrm{~b} \\
\mathrm{~N}=99\end{array}$ \\
\hline Unstandardized Coefficients & Control & $\mathrm{VC} \rightarrow \mathrm{GEP}$ & $\begin{array}{c}\text { Green } \\
\text { Policy } \rightarrow \text { GEP }\end{array}$ & \\
\hline Constant & $\begin{array}{l}20.113+ \\
(11.386)\end{array}$ & $\begin{array}{l}19.874+ \\
(11.176)\end{array}$ & $\begin{array}{c}8.844 \\
(7.083)\end{array}$ & $\begin{array}{c}5.949 \\
(11.002)\end{array}$ \\
\hline Firm Performance (ROS) & $\begin{array}{l}.003 \\
(.326)\end{array}$ & $\begin{array}{l}-.015 \\
(.321)\end{array}$ & $\begin{array}{l}.029 \\
(.201)\end{array}$ & $\begin{array}{l}-.140 \\
(.300)\end{array}$ \\
\hline Firm Size (Employee log) & $\begin{array}{l}6.380^{*} \\
(2.922)\end{array}$ & $\begin{array}{l}5.245+ \\
(2.919)\end{array}$ & $\begin{array}{c}2.631 \\
(1.893)\end{array}$ & $\begin{array}{c}2.934 \\
(2.779)\end{array}$ \\
\hline SIC $2000 \&$ 2100: Food / Tobacco Products & $\begin{array}{c}-34.889 * * * \\
(7.626)\end{array}$ & $\begin{array}{c}-33.169 * * * \\
(7.531)\end{array}$ & $\begin{array}{c}-29.397 * * * \\
(5.504)\end{array}$ & $\begin{array}{c}-31.809 * * * \\
(7.008)\end{array}$ \\
\hline $\begin{array}{l}\text { SIC } 2200 \text { to 2500: (Textile Mill Products/Apparel/ Lumber and Wood / Furniture } \\
\text { and Fixtures) }\end{array}$ & $\begin{array}{c}-1.147 \\
(12.931)\end{array}$ & $\begin{array}{c}3.980 \\
(12.929)\end{array}$ & $\begin{array}{c}6.454 \\
(8.842)\end{array}$ & $\begin{array}{c}9.052 \\
(12.088) \\
\end{array}$ \\
\hline SIC 2600 and 2700: ( Paper/ Printing, Publishing) & $\begin{array}{l}-30 . .396^{*} \\
(14.665)\end{array}$ & $\begin{array}{l}-28.447+ \\
(14.424)\end{array}$ & $\begin{array}{c}-21.503 * * \\
(7.503) \\
\end{array}$ & $\begin{array}{l}-31.072 * \\
(13.423)\end{array}$ \\
\hline $\begin{array}{l}\text { SIC3000 to 3400: Rubber / Stone, Clay, Glass / Primary Metal / Fabricated Metal } \\
\text { Products }\end{array}$ & $\begin{array}{l}-15.890^{*} \\
(10.386) \\
\end{array}$ & $\begin{array}{c}-9.630 \\
(10.629) \\
\end{array}$ & $\begin{array}{l}-4.523 \\
(6.834)\end{array}$ & $\begin{array}{l}-5.488 \\
(9.936)\end{array}$ \\
\hline SIC 3500 Industrial / Computer Equipment & $\begin{array}{l}19.527 \\
(7.615)\end{array}$ & $\begin{array}{c}25.408^{* *} \\
(7.990)\end{array}$ & $\begin{array}{c}17.682^{* *} \\
(5.382)\end{array}$ & $\begin{array}{c}26.334 * * \\
(7.429)\end{array}$ \\
\hline SIC 3600: 3600 - Electronic Equipment & $\begin{array}{l}12.828 \\
(8.931)\end{array}$ & $\begin{array}{l}19.258^{*} \\
(9.294)\end{array}$ & $\begin{array}{c}17.787^{* *} \\
(5.686)\end{array}$ & $\begin{array}{l}19.264 * \\
(8.637)\end{array}$ \\
\hline SIC3700 Transportation Equipment & $\begin{array}{c}4.854 \\
(9.993)\end{array}$ & $\begin{array}{c}12.175 \\
(10.420)\end{array}$ & $\begin{array}{c}10.849+ \\
(6.417)\end{array}$ & $\begin{array}{l}18.405+ \\
(9.818)\end{array}$ \\
\hline SIC 3800 \& 3900: Instruments /Miscellaneous manufacturing & $\begin{array}{l}20.015^{*} \\
(9.702)\end{array}$ & $\begin{array}{c}24.317 * \\
(9.745)\end{array}$ & $\begin{array}{c}27.603 * * * \\
(5.886)\end{array}$ & $\begin{array}{c}28.097 * * \\
(9.110)\end{array}$ \\
\hline Verbal Commitment & & $\begin{array}{l}2.591^{*} \\
(1.244)\end{array}$ & & $\begin{array}{l}.910 \\
(.736)\end{array}$ \\
\hline Green Policy Management & & & $\begin{array}{c}.469 * * * \\
(.082)\end{array}$ & $\begin{array}{c}.447 * * * \\
(.117)\end{array}$ \\
\hline R-Square & .426 & .453 & .497 & .533 \\
\hline Adjusted R & .361 & .384 & .464 & .468 \\
\hline R-Square change & $.426 * * *$ & $.027 *$ & $.096 * * *$ & $.107 * * *$ \\
\hline
\end{tabular}


TABLE 10a: Regression Results Predicting GEP: Network Effects

\begin{tabular}{|c|c|c|c|c|c|}
\hline Hypothesis \# & & $\mathrm{H} 7$ & $\mathrm{H} 8$ & H9 & \\
\hline & M1 & M2 & M3 & M4 & M5 \\
\hline Unstandardized Coefficients & $\begin{array}{l}\text { M1 Control } \\
(\mathrm{N}=159)\end{array}$ & $\begin{array}{c}\text { Institutional } \\
\text { Diversity } \rightarrow \text { GEP } \\
(\mathrm{N}=159) \\
\end{array}$ & $\begin{array}{c}\text { Geographic } \\
\text { Dispersion } \\
\rightarrow \text { GEP N=159 }\end{array}$ & $\begin{array}{c}\text { Density } \rightarrow \text { GEP } \\
N=162\end{array}$ & $\begin{array}{c}\text { All } \\
\mathrm{N}=158\end{array}$ \\
\hline Constant & $\begin{array}{c}21.947 * * \\
(8.012)\end{array}$ & $\begin{array}{c}34.370^{* *} \\
(7.614)\end{array}$ & $\begin{array}{l}33.680 * * * \\
(7.847)\end{array}$ & $\begin{array}{l}33.179 * * * \\
(7.980)\end{array}$ & $\begin{array}{c}33.332 * * * \\
(8.328)\end{array}$ \\
\hline Firm Performance (ROS) & $\begin{array}{c}.090 \\
(.236) \\
\end{array}$ & $\begin{array}{l}-.052 \\
(.217)\end{array}$ & $\begin{array}{c}-.001 * * \\
(.220)\end{array}$ & $\begin{array}{l}-.057 \\
(.211) \\
\end{array}$ & $\begin{array}{l}-.010 \\
(.226)\end{array}$ \\
\hline Firm Size (Employee log) & $\begin{array}{l}6.468 * * \\
(2.084)\end{array}$ & $\begin{array}{c}1.929 \\
(2.062)\end{array}$ & $\begin{array}{c}1.843 \\
(2.049)\end{array}$ & $\begin{array}{c}2.432 \\
(2.271)\end{array}$ & $\begin{array}{c}2.006 \\
(2.368)\end{array}$ \\
\hline SIC $2000 \&$ 2100: Food / Tobacco Products & $\begin{array}{c}-33.922 * * * \\
(6.361)\end{array}$ & $\begin{array}{c}-31.647 * * * \\
(5.840)\end{array}$ & $\begin{array}{c}-31.217 * * * \\
(5.822)\end{array}$ & $\begin{array}{c}-32 . .026 * * * \\
(5.893)\end{array}$ & $\begin{array}{c}-31.351 * * * \\
(6.199)\end{array}$ \\
\hline $\begin{array}{l}\text { SIC } 2200 \text { to 2500: (Textile Mill Products/Apparel/ Lumber } \\
\text { and Wood / Furniture and Fixtures) }\end{array}$ & $\begin{array}{c}-8.862 \\
(10.375)\end{array}$ & $\begin{array}{c}3.090 \\
(9.835)\end{array}$ & $\begin{array}{c}3.192 \\
(9.710)\end{array}$ & $\begin{array}{c}1.715 \\
(9.680)\end{array}$ & $\begin{array}{c}3.942 \\
(10.407)\end{array}$ \\
\hline SIC 2600 and 2700: ( Paper/ Printing, Publishing) & $\begin{array}{l}-21.322^{*} \\
(9.239)\end{array}$ & $\begin{array}{c}-19.915^{*} \\
(8.402)\end{array}$ & $\begin{array}{c}-19.555^{*} \\
(8.462)\end{array}$ & $\begin{array}{c}-20.442^{*} \\
(8.404)\end{array}$ & $\begin{array}{c}-19.459^{*} \\
(8.650)\end{array}$ \\
\hline $\begin{array}{l}\text { SIC3000 to 3400: Rubber / Stone, Clay, Glass / Primary } \\
\text { Metal / Fabricated Metal Products }\end{array}$ & $\begin{array}{l}-8.120 \\
(7.991)\end{array}$ & $\begin{array}{l}-2.724 \\
(7.326)\end{array}$ & $\begin{array}{l}-1.574 \\
(7.477)\end{array}$ & $\begin{array}{l}-3.316 \\
(7.421)\end{array}$ & $\begin{array}{l}-1.821 \\
(7.717)\end{array}$ \\
\hline SIC 3500 Industrial / Computer Equipment & $\begin{array}{c}11.235+ \\
(6.261)\end{array}$ & $\begin{array}{c}17.876^{* *} \\
(5.801)\end{array}$ & $\begin{array}{c}18.909^{* *} \\
(5.904)\end{array}$ & $\begin{array}{c}17.849^{* *} \\
(5.686)\end{array}$ & $\begin{array}{c}18.946^{* *} \\
(6.132)\end{array}$ \\
\hline SIC 3600: 3600 - Electronic Equipment & $\begin{array}{r}15.801^{*} \\
(6.638)\end{array}$ & $\begin{array}{l}19.906^{*} \\
(6.082))\end{array}$ & $\begin{array}{c}20.126 * * \\
(6.143)\end{array}$ & $\begin{array}{c}19.321 * * \\
(6.080)\end{array}$ & $\begin{array}{c}20.209^{* *} \\
(6.408)\end{array}$ \\
\hline SIC3700 Transportation Equipment & $\begin{array}{c}.305 \\
(7.327)\end{array}$ & $\begin{array}{c}12.647 * * \\
(6.082)\end{array}$ & $\begin{array}{c}13.642+ \\
(7.132)\end{array}$ & $\begin{array}{c}12.089+ \\
(7.221)\end{array}$ & $\begin{array}{c}13.592+ \\
(7.715)\end{array}$ \\
\hline $\begin{array}{l}\text { SIC } 3800 \text { \& 3900: Instruments /Miscellaneous } \\
\text { manufacturing }\end{array}$ & $\begin{array}{l}15.005^{*} \\
(7.052)\end{array}$ & $\begin{array}{c}21.314^{* *} \\
(6.500)\end{array}$ & $\begin{array}{c}21.957 * * \\
(6.636)\end{array}$ & $\begin{array}{l}23.028 * * * \\
(6.331)\end{array}$ & $\begin{array}{c}21.966^{* *} \\
(6.804)\end{array}$ \\
\hline Green Policy Management & & $\begin{array}{l}.515 * * * \\
(.088)\end{array}$ & $\begin{array}{c}.528 * * * \\
(.091)\end{array}$ & $\begin{array}{c}.524 * * * \\
(.089)\end{array}$ & $\begin{array}{l}.536 * * * \\
(.095)\end{array}$ \\
\hline Network Environmental Institutional Diversity & & $\begin{array}{c}-.790 \\
(1.6888)\end{array}$ & & & $\begin{array}{c}-.844 \\
(1.869)\end{array}$ \\
\hline $\begin{array}{l}\text { Network Environmental Institutional Diversity X Green } \\
\text { Policy Management }\end{array}$ & & $\begin{array}{l}-.064 \\
(.085)\end{array}$ & & & $\begin{array}{l}-.069 \\
(.094)\end{array}$ \\
\hline Network Geographic Dispersion & & & $\begin{array}{l}-1.339 \\
(2.660)\end{array}$ & & $\begin{array}{c}001 \\
(.004)\end{array}$ \\
\hline Network Geographic Dispersion X Green Policy & & & .034 & & .000 \\
\hline
\end{tabular}




\begin{tabular}{|c|c|c|c|c|c|}
\hline Management & & & $(.064)$ & & $(.000)$ \\
\hline Network Density & & & & $\begin{array}{l}-.035 \\
(.103) \\
\end{array}$ & $\begin{array}{c}.005 \\
(.119) \\
\end{array}$ \\
\hline Network Density X Green Policy Management & & & & $\begin{array}{c}-.001 \\
(.004)\end{array}$ & $\begin{array}{c}.000 \\
(.005)\end{array}$ \\
\hline R-Square & .364 & .486 & .322 & .490 & .489 \\
\hline Adjusted R & .321 & .440 & .439 & .446 & .426 \\
\hline R-Square change & $.364 * * *$ & $.122 * * *$ & $.210 * * *$ & $.121 * * *$ & $.125 * * *$ \\
\hline
\end{tabular}


TABLE 11: Regression Predicting Green Policy Management

\begin{tabular}{|c|c|c|}
\hline $\begin{array}{l}\mathrm{H} 2 \\
\mathrm{~N}=146\end{array}$ & M1 & M2 \\
\hline Unstandardized Coefficients & Control & $\begin{array}{c}\text { VC } \rightarrow \text { Green } \\
\text { Policy } \\
\text { Management }\end{array}$ \\
\hline Constant & $\begin{array}{c}31.487 * * \\
(10.162)\end{array}$ & $\begin{array}{c}31.140^{* *} \\
(9.558)\end{array}$ \\
\hline Firm Performance (ROS) & $\begin{array}{c}.305 \\
(.291)\end{array}$ & $\begin{array}{c}.278 \\
(.274)\end{array}$ \\
\hline Firm Size (Employee log) & $\begin{array}{c}6.815^{* * * *} \\
(2.608)\end{array}$ & $\begin{array}{l}5.168^{*} \\
(2.496)\end{array}$ \\
\hline SIC 2000 \& 2100: Food / Tobacco Products & $\begin{array}{l}-5.537 \\
(6.807)\end{array}$ & $\begin{array}{l}-3.041 \\
(6.441)\end{array}$ \\
\hline SIC 2200 to 2500: (Textile Mill Products/Apparel/ Lumber and Wood / Furniture and Fixtures) & $\begin{array}{c}-18.779^{*} \\
(8.922)\end{array}$ & $\begin{array}{c}-11.342 \\
(11.057)\end{array}$ \\
\hline SIC 2600 and 2700: ( Paper/ Printing, Publishing) & $\begin{array}{c}3.043 \\
(13.088)\end{array}$ & $\begin{array}{c}5.871 \\
(12.336)\end{array}$ \\
\hline SIC3000 to 3400: Rubber / Stone, Clay, Glass / Primary Metal / Fabricated Metal Products & $\begin{array}{c}-18.779 \\
(11.541)\end{array}$ & $\begin{array}{l}-9.263 \\
(9.089)\end{array}$ \\
\hline SIC 3500 Industrial / Computer Equipment & $\begin{array}{c}-10.602^{*} \\
(6.796)\end{array}$ & $\begin{array}{c}-2.072 \\
(6.833)\end{array}$ \\
\hline SIC 3600: 3600 - Electronic Equipment & $\begin{array}{c}-9.339 \\
(7.971)\end{array}$ & $\begin{array}{c}-.012 \\
(7.948)\end{array}$ \\
\hline SIC3700 Transportation Equipment & $\begin{array}{c}-24.549 * * \\
(8.919)\end{array}$ & $\begin{array}{c}-13.930 \\
(8.911)\end{array}$ \\
\hline SIC 3800 \& 3900: Instruments /Miscellaneous manufacturing & $\begin{array}{c}-14.694 \\
(8.659)\end{array}$ & $\begin{array}{l}-8.454 \\
(8.334)\end{array}$ \\
\hline Verbal Commitment & & $\begin{array}{c}3.758 * * \\
(1.064)\end{array}$ \\
\hline R-Square & .190 & .291 \\
\hline Adjusted R & .097 & .202 \\
\hline R-Square change & $.190 *$ & $.102 * *$ \\
\hline
\end{tabular}


TABLE 12: Regression Predicting Reputation

\begin{tabular}{|c|c|c|c|c|c|}
\hline & M1 & M2 & M3 & M4 & M5 \\
\hline Unstandardized Coefficients & $\begin{array}{l}\text { Control } \\
\mathrm{N}=184\end{array}$ & $\begin{array}{c}\mathrm{H} 4 \\
\mathrm{VC} \rightarrow \mathrm{Rep} \\
\mathrm{N}=99\end{array}$ & $\begin{array}{c}\text { H5 } \\
\text { Green Policy- } \rightarrow \\
\text { Rep }(\mathrm{N}=184)\end{array}$ & $\begin{array}{c}\text { H6 } \\
\text { GEP--- } \rightarrow \text { Rep } \\
(\mathrm{N}=184)\end{array}$ & $\mathrm{N}=144$ \\
\hline Constant & $\begin{array}{l}50.075 * * * \\
(3.206)\end{array}$ & $\begin{array}{l}30.533 * * * \\
(6.152)\end{array}$ & $\begin{array}{c}28.312 * * * \\
(3.289)\end{array}$ & $\begin{array}{c}38.998 * * * \\
(3.318)\end{array}$ & $\begin{array}{c}32.993 * * * \\
(3.838)\end{array}$ \\
\hline Firm Performance (ROS) & $\begin{array}{l}.492 * * \\
(.155)\end{array}$ & $\begin{array}{l}.614 * * \\
(.151)\end{array}$ & $\begin{array}{l}.200+ \\
(.114)\end{array}$ & $\begin{array}{l}.217+ \\
(.129)\end{array}$ & $\begin{array}{l}.374 * * \\
(.135)\end{array}$ \\
\hline Revenue (2010) & $\begin{array}{l}6.693 \mathrm{E}-5^{*} \\
(.000)\end{array}$ & $\begin{array}{l}6.599^{*} \\
(.000)\end{array}$ & $\begin{array}{l}6.85^{*} \\
(.000)\end{array}$ & $\begin{array}{l}8.41 * * \\
(.000)\end{array}$ & $\begin{array}{l}5.278 \mathrm{E}-5+ \\
(.000)\end{array}$ \\
\hline SIC $2000 \&$ 2100: Food / Tobacco Products & $\begin{array}{l}-6.070 \\
(4.158)\end{array}$ & $\begin{array}{r}-12.236 \\
(4.121)\end{array}$ & $\begin{array}{l}-5.158 \\
(3.138)\end{array}$ & $\begin{array}{l}-.697 \\
(3.797)\end{array}$ & $\begin{array}{l}-2.916 \\
(3.939) \\
\end{array}$ \\
\hline $\begin{array}{l}\text { SIC } 2200 \text { to 2500: (Textile Mill Products/Apparel/ Lumber } \\
\text { and Wood / Furniture and Fixtures) }\end{array}$ & $\begin{array}{l}-7.631 \\
(6.309)\end{array}$ & $\begin{array}{l}-13.246 \\
(6.987)\end{array}$ & $\begin{array}{c}1.996 \\
(5.034) \\
\end{array}$ & $\begin{array}{l}-2.818 \\
(5.685)\end{array}$ & $\begin{array}{l}-3.368 \\
(5.549)\end{array}$ \\
\hline SIC 2600 and 2700: ( Paper/ Printing, Publishing) & $\begin{array}{c}5.467 \\
(5.639)\end{array}$ & $\begin{array}{c}1.333 \\
(7.924)\end{array}$ & $\begin{array}{l}8.595+ \\
(4.362)\end{array}$ & $\begin{array}{l}13.579 * * \\
(5.001)\end{array}$ & $\begin{array}{c}7.396 \\
(4.934)\end{array}$ \\
\hline $\begin{array}{l}\text { SIC3000 to 3400: Rubber / Stone, Clay, Glass / Primary Metal } \\
\text { / Fabricated Metal Products }\end{array}$ & $\begin{array}{c}1.235 \\
(4.933) \\
\end{array}$ & $\begin{array}{r}-10.887 \\
(5.612)\end{array}$ & $\begin{array}{c}5.345 \\
(3.853) \\
\end{array}$ & $\begin{array}{c}3.590 \\
(4.358) \\
\end{array}$ & $\begin{array}{c}4.663 \\
(4.286) \\
\end{array}$ \\
\hline SIC 3500 Industrial / Computer Equipment & $\begin{array}{c}-.295 \\
(3.953) \\
\end{array}$ & $\begin{array}{l}-3.097 \\
(4.114)\end{array}$ & $\begin{array}{l}6.041^{*} \\
(3.050)\end{array}$ & $\begin{array}{c}-.195 \\
(3.502)\end{array}$ & $\begin{array}{c}1.291 \\
(3.592) \\
\end{array}$ \\
\hline SIC 3600: 3600 - Electronic Equipment & $\begin{array}{l}-7.053 \\
(4.522)\end{array}$ & $\begin{array}{r}-11.151 \\
(4.826) \\
\end{array}$ & $\begin{array}{c}-.189 \\
(3.288) \\
\end{array}$ & $\begin{array}{l}-4.725 \\
(3.813) \\
\end{array}$ & $\begin{array}{l}-5.765 \\
(4.040) \\
\end{array}$ \\
\hline SIC3700 Transportation Equipment & $\begin{array}{l}-5.251 \\
(4.537)\end{array}$ & $\begin{array}{c}-13.090 \\
(5.400)\end{array}$ & $\begin{array}{c}5.690 \\
(3.572) \\
\end{array}$ & $\begin{array}{l}-2.086 \\
(3.939) \\
\end{array}$ & $\begin{array}{c}1.021 \\
(4.154) \\
\end{array}$ \\
\hline SIC 3800 \& 3900: Instruments /Miscellaneous manufacturing & $\begin{array}{c}-5.484 \\
(4.441) \\
\end{array}$ & $\begin{array}{c}-6.081 \\
(5.242) \\
\end{array}$ & $\begin{array}{c}2.603 \\
(3.431) \\
\end{array}$ & $\begin{array}{l}-6.157 \\
(3.994) \\
\end{array}$ & $\begin{array}{l}-2.228 \\
(4.223) \\
\end{array}$ \\
\hline Verbal Commitment & & $\begin{array}{c}1.467^{*} \\
(.670)\end{array}$ & & & $\begin{array}{c}.465 \\
(.082) \\
\end{array}$ \\
\hline Green Policy Management & & & $\begin{array}{c}.370 * * * \\
(.042)\end{array}$ & & $\begin{array}{l}.234 * * \\
(.058)\end{array}$ \\
\hline GEP & & & & $\begin{array}{c}.200 * * * \\
(.044)\end{array}$ & $\begin{array}{c}.051 \\
(.050)\end{array}$ \\
\hline R-Square & .156 & .380 & .392 & .219 & .488 \\
\hline Adjusted R & .092 & .302 & .353 & .169 & .409 \\
\hline R-Square change & $.156^{*}$ & $.035 *$ & $.268 * * *$ & $.095 * * *$ & $.142 * * *$ \\
\hline
\end{tabular}




\section{RQ \#1: Discussion and Contributions}

The results from this comprehensive examination revealed that firms'verbal commitment did predict firm environmental performance and their green policy management. This relationship supports the literature explaining that what firms articulate in their mission/vision statements and websites is indicative of the internal policies that guide operations and the actions they actually perform (Bartkus \& Glassman, 2008; Hart, 1995; Onkila, 2009). Building on the control literature (Harzing, 1999; Geringer \& Hebert, 1989; Ambos \& Schlegelmilch, 2007: 475), verbal commitment as a reflection of the firm's shared values which is an informal control mechanism and Green Policy Management as a mechanism of formalized control predicted GEP. Therefore, the results show that both forms of controls are effective in increasing environmental performance. However, when both were included in the model, only Green Policy Management had a significant positive relationship. Interestingly, the findings also support that firms that expressed verbal commitment to the environment also had higher environmental reputation than others which did not. These findings are supported by signaling theory (Myers \& Majluf, 1984; Behrend Baker, \& Thompson, 2009), which explains that mission statements and reports will serve as signals of firms' actions. Green Policy Management was found to be a stable and significant variable in predicting GEP and environmental reputation. This finding is supported by the literature arguing that MNCs are increasingly implementing more internally driven selfregulation environmental policies (Brown, Derr, Renn, \& White, 1993; Dowell, Hart, \& Yeung, 2000) to guide their behavior. For these firms, effectiveness in managing their green policies is likely to be the driver for developing green competencies and a source of 
competitive advantage. Therefore, when differentiating between firms' environmental consciousness, scholars should investigate more internal environmental firm policies, because they are likely to be more indicative of their actions. Future studies can and should examine in more detail this construct, focusing on the challenges that can arise from the actual process of implementation of green policies, while taking into account the variations at the subsidiary level that can have an impact. Environmental reputation was found to be driven by verbal environmental commitment, green policy management and GEP, which indicates the importance for firms to properly use these factors to send the correct signals to investors and other key stakeholders, which contributes to the stakeholders' management literature (Mitchell et al., 1997; Donaldson \& Preston, 1995; Bartkus \& Glassman, 2008).

The presented VMPR framework took an internal perspective to examining the core elements of CEM by studying how the different layers are related, investigating the impact of informal controls manifested in firms' verbal commitments reflecting their intentions, and substantiated intentions in the form of formal controls reflected via environmental policy on environmental performance. While each of these elements has been studied individually (Bartkus \& Glassman, 2008; Christmann 2004, Dawkins \& Fraas, 2010; Behrend \& Baker, 2009) this study captures multiple CEM constructs in a single model to distinguish between mechanisms of control. The framework presented also sought to differentiate firms on "what they say they do" vs. "what they set out to do" and "what they actually end up doing". This framework serves as the base model or starting point for studying challenges and for breaking the green free rider trend that evidence suggests describes some MNCs today. 
The findings from investigations of the VMPR framework support the literature emphasizing the importance of managerial decisions as drivers of CEM (Rugman \& Verbeke, 1998; Buysse \& Verbeke, 2003; Christmann, 2004) versus the previous literature that puts greater emphasis on firm's reactionary behavior to external government regulations (Birdsall \& Wheeler, 1992). We found that effectiveness in managing green policies is a strong driver for developing green competencies/competitive advantage. The findings support the literature on MNC implementation of voluntary self regulated environmental policies (Christmann, 2004) as opposed to studies that consider the MNC as a seeker of pollution havens (Gladwin, 1987; Zyglidopoulos, 2002). In addition, the study has sought to investigate the "language" aspect of CEM, which is regarded as "missing" (Onkila, 2009). The research findings found support for the role of HQ's verbal commitment and policy as key drivers of firms' environmental actions and the importance of using multiple control mechanisms to guide MNC-wide environmental practices. Finally, an underlying contribution of this framework is that it captures multiple stakeholders' perspectives, with the HQ being the main actor behind verbal commitment, subsidiaries being the main actors behind implementation (GEP), and finally external stakeholders determining reputation.

\section{RQ \#2: Discussion and Contributions}

While hypothesized to negatively moderate the relationship between Environmental Management Standards and actual GEP due to increased management complexities, Environmental Institutions Network Diversity was not found to have a significant impact. Network Density and Network Dispersion were also hypothesized to increase the complexities of managing the subsidiary network and hence negatively moderate the 
relationship between Green Policy Management and actual GEP. These hypotheses were also not supported, contrary to expectations.

Network complexities did not make it more or less difficult for the MNC to achieve GEP. While this may be attributed to measurement error, based on traditional network theory, this finding is indeed unexpected, given that the dimensions of density, dispersion, and diversity have been all found to hinder uniform policy adoption, communication and knowledge flow for the most part in the previous MNC management literature (Kostova \& Roth, 2002; Ghemawat, 2001; Bouquet \& Birkinshaw, 2008; Brass, et al., 2004). Nevertheless, such a unique finding is of itself a contribution to the literature because it tested Aragón-Correa and Sharma's (2003) proposition about the degree of complexity's moderating effect, with no significant relationship found.

The lack of significance for the interaction effect can also be explained by the rational that firms are moving more towards standardized and uniform adoption of environmental performance across units no matter how many units are in the network or how geographically dispersed they may be, supporting the trends of effective standardization of environmental operations within the subsidiary network (Christmann 2004, Aguilera-caracuel et al., 2012). The lack of significance can also be interpreted by strategy scholars to support the literature on dynamic capabilities, which Teece and Shuen (1997) refer to as "the ability to integrate, build, and reconfigure internal and external competencies to address rapidly-changing environments". Firms that have developed green dynamic capabilities are more likely to be successful in deploying them through their subsidiary networks, despite the institutional 
contexts they operate within, and despite the number of subsidiaries in the networks and how geographically distant they are from HQ. Therefore, future studies can examine dynamic capabilities as the moderator of the green policy to green practice relationship, to determine whether firms have the dynamic capabilities needed to implement these policies.

This finding supports the current literature which explains that leading Fortune 500 firms are not seeking pollution havens with weak institutional infrastructure to conduct operations (Christmann, 2004; Christmann \& Taylor, 2001). This supports the perspective that more firms are seeking to standardize and adopt uniform practices regardless of how diverse the environmental institutional context is or how many units they need to manage within the MNC network of subsidiaries. This supports the trends of standardization of environmental guidelines worldwide (Birdsall \& Wheeler, 1992; King \& Shaver, 2001). Firms may not act as explained by transaction cost theory in an opportunistic manner taking advantage of weak environmental institutions; instead, MNCs are taking the upper hand and becoming more self regulated (Christmann \& Taylor, 2001). Firm characteristics and capabilities are shaping their environmental strategies (Christmann, 2000). Firms are seeking to streamline operations and facilitate the transfer of best practices behind complementarities between firm and host market assets (Teece, 1986) and operating in diverse institutional contexts does not have a significant impact.

This is supported by the literature explaining that firms are not seeking to comply with new environmental regulations, but are also developing "green capabilities which allow them to outperform competitors on environmental strategy grounds alone" (Rugman \& Verbeke, 
1998). In this context, self regulation behaviors and their results are likely to exceed those expected from governmental compliance in a host market (Christmann, 2004).

The perception that MNCs are moving to more self regulation, regardless of where they invest, creates numerous avenues for further research in the direction of investigating internal firm capabilities driving GEP. This finding supports the growing literature depicting emerging trends of environmental uniformity and standardization (Christmann, 2004; Arago'n-Correa \& Sharma, 2003) as self driven goals, which firms are voluntarily pursuing. Such behavior is driven more by firms' pursuit of gaining competitive advantages than external stakeholder pressure (Fraj-Andrés, Martínez-Salinas \& Matute-Vallejo, 2009). This described firm behavior is also in agreement with social cognitive theory of self regulation (Bandura, 1991). This theory has not been incorporated much in strategic management at the firm network level and to an even lesser degree in the CEM literature. Instead, it has mostly examined individuals; yet the rational is very relevant to explaining organizations' environmental behavior. Bandura (1991) explains that when entities have clear goals that guide their actions, they self regulate their actions, weighing in their own personal gains from adopting a specific practice, including expected pressures from significant stakeholder groups. In fact, he describes self regulated systems as “...provid(ing) the very basis of purposeful actions" (Bandura, 1991: 248). Therefore, it is such self regulation which allows the organization to smoothly and effectively adapt to the changing environment. This is also supported by the MNC literature on benefits from standardization of different functions to gain the synergies of an integrated value chain, and exchange of resources (AguileraCaracuel, et al., 2012; Mueller et al., 2009). For these firms, due to the combination of the 
green consumerism trend (BusinessWire, 2010), standardization of global regulations (Buysse \& Verbeke, 2003) and the green race (Mitchell \& Ramey, 2011), they are left with no other choice but to build green competitive advantage, regardless of how many, how distant or how different their subsidiaries may be.

The above has provided insights into new ways for scholars to approach how organizations behave and how best these organizations are to be managed. While international institutional context remains important, the MNC as a complex adaptive system has figured out ways to preserve its core identity and practice despite where it operates.

Another explanation for the above findings could be that network effects challenges are overpowered by another variable that is not captured in this study, like firm leadership, for example. Another possibility is that network dimensions will increase the challenges in other elements of CEM, but not in the policy to performance relationship. An additional possibility is that the model as it stands is underspecified because it does not capture challenges stemming from subsidiary level management or control, where possibly network dimensions will matter more.

Future studies can also challenge the above perspective by arguing that the relationship between MNC green policy management and GEP may be moderated by other factors which may not have been captured in this study. This may include variables captured more at the "subsidiary level" versus "network level" variables, which are not examined in the scope of this study. Future scholars can investigate moderating factors such as subsidiary size, scope, 
and management style as potential moderators of the relationship between green policy management and green actual practice. Another set of variables to investigate could be related to subsidiary level capabilities (Christmann, 2000).

\section{POST HOC SEGMENTATION OF FIRMS}

According to Corporate Register (2011), the largest online directory of firms' sustainability reports across the globe, the number of sustainability reports has reached a milestone of over 30,000 corporate responsibility and sustainability reports from almost 7,500 companies around the world. While this trend is a positive one, it also raises some questions related to potential free riders, especially when being an environmentally responsible firm is an attractive "tag" to have for firms to boost their corporate reputation and to attract investors. Research question \#1 sought to depict the differences between firms as HQ's use of verbal commitment and green management policy to control the firm, but for the MNC, we need to also account for its international element. Therefore, in the upcoming post hoc analysis, the next section seeks to make distinctions between firms' GEP and key subsidiary network dimensions. With the current flux of MNCs issuing environmental sustainability reports, this can be used as a tool through which investors can discriminate between multiple firms in accordance to their GEP and their international operations.

\section{Typology: Two x Two Matrix}

Payne and Raiborn (2001) explain that firms' behaviors can range from compliance with the law all the way to making environmental performance its distinct competitive advantage. So 
conceptually, this suggests that there could be a difference between firms on dimensions of where they invest and their environmental performance. While this study focuses on the challenges that MNCs face in deploying global environmental policies, some may argue that some firms intentionally seek to operate in markets with less stringent environmental standards. A typology can be created when we try to answer the question of how can MNCs be segmented in relation to their host market's environmental institutional context. The typology is presented in a 2x2 matrix shown in Figure 10.

The first quadrant represents companies that have a low GEP score and also operate networks with a low Environmental Institutional Network Score. These firms would be labeled as "exploiters". They are not committed to environmental compliance and the location of their international operations is a reflection of this. In quadrant II, companies have a low GEP, but a high Environmental Institutional Network Score, reflecting operations in markets that have high commitment to the environment. These companies can be labeled as being "compliant", and perhaps through time, they are likely to increase their environmental performance as a function of operating in countries with high environmental commitments. In quadrant III, companies have a high performance score, but operate in locations with a low Environmental Institutional Network Score. In this context, it is likely that these firms are more capable of acting out the role of the "MNC as an agent of change", because these firms are committed to performing environmentally well, even if the host market context does not support them in doing so. These firms, if they possess enough bargaining power, can be trend setters and can actually shape the local institutions of these host markets. Finally, in quadrant IV, a firm would be characterized as "green competent" if in fact it had a high GEP and a high 
Environmental Institutional Network Score. This company is likely to want to build its global competitiveness based on development of green competencies.

Two x Two Firm Typology

Figure 10
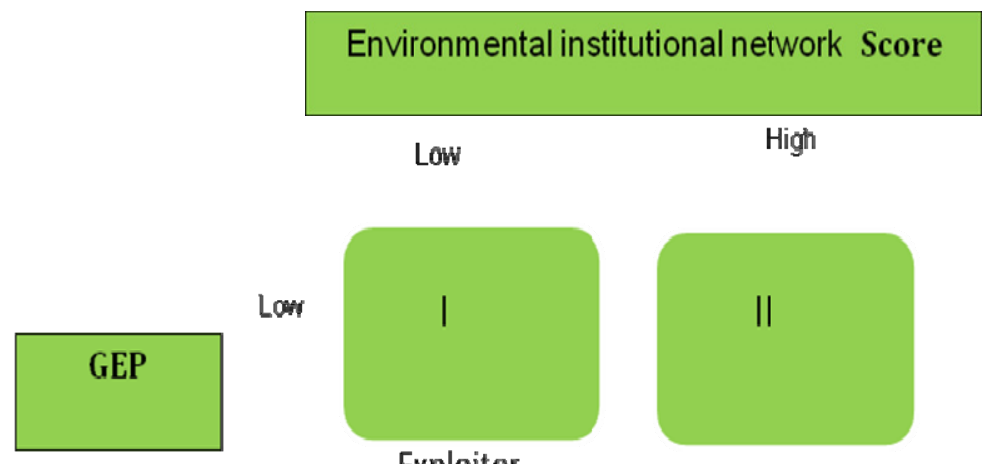

Exploiter

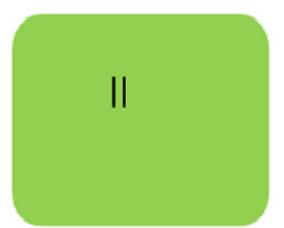

Compliant
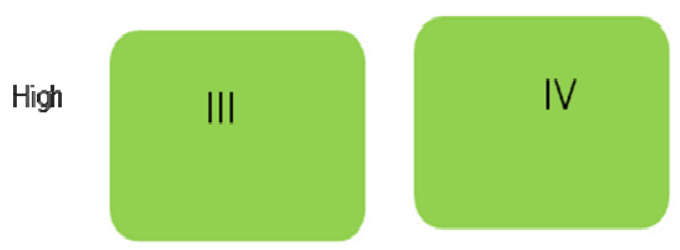

Agent of

Change

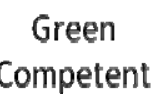

Therefore, firms can be classified according to 4 quadrants:

- Quadrant I : Low GEP-Low environmental institutional network score

- Quadrant II: Low GEP- High environmental institutional network score

- Quadrant III: High GEP- Low environmental institutional network score

- Quadrant IV. High GEP- High environmental iinstitutional network score 
The first step in this segmentation analysis involved calculating the median for the key variables: GEP and Network institutional dimensions. The median was used to create cut offs (high/low) for this classification, such that " 1 " was coded if above the median and "0" if below the median. Using these cutoffs, a $2 \times 2$ matrix was created which will be used to predict different firm outcomes. The below table 13 presents the results of the cross tabulations used to develop the $2 \times 2$ classification. 
TABLE 13: GEP and Environmental Institutional Network Score

\section{GEP * Environmental Institutional Network Score} Cross tabulation

\begin{tabular}{|c|c|c|c|c|c|}
\hline & & & \multicolumn{2}{|c|}{$\begin{array}{c}\text { Environmental Institutional } \\
\text { network score }\end{array}$} & \multirow[b]{2}{*}{ Total } \\
\hline & & & Low & High & \\
\hline \multirow[t]{8}{*}{ GEP } & Low & Count & 45 & 39 & 84 \\
\hline & & $\%$ within GEP & $53.6 \%$ & $46.4 \%$ & $100.0 \%$ \\
\hline & & $\%$ within Environmental Institutional network score & $55.6 \%$ & $48.1 \%$ & $51.9 \%$ \\
\hline & & $\%$ of Total & $27.8 \%$ & $24.1 \%$ & $51.9 \%$ \\
\hline & High & Count & 36 & 42 & 78 \\
\hline & & $\%$ within GEP & $46.2 \%$ & $53.8 \%$ & $100.0 \%$ \\
\hline & & \% within Environmental Institutional network & $44.4 \%$ & $51.9 \%$ & $48.1 \%$ \\
\hline & & $\%$ of Total & $22.2 \%$ & $25.9 \%$ & $48.1 \%$ \\
\hline \multirow[t]{4}{*}{ Total } & & Count & 81 & 81 & 162 \\
\hline & & $\%$ within GEP & $50.0 \%$ & $50.0 \%$ & $100.0 \%$ \\
\hline & & $\%$ within Environmental institutional network score & $100.0 \%$ & $100.0 \%$ & $100.0 \%$ \\
\hline & & $\%$ of Total & $50.0 \%$ & $50.0 \%$ & $100.0 \%$ \\
\hline
\end{tabular}

\begin{tabular}{|l|c|c|c|c|c|}
\hline & Value & df & $\begin{array}{c}\text { Asymp. Sig. (2- } \\
\text { sided) }\end{array}$ & $\begin{array}{c}\text { Exact Sig. (2- } \\
\text { sided) }\end{array}$ & Exact Sig. (1-sided) \\
\hline Pearson Chi-Square & $.890^{\mathrm{a}}$ & 1 & .345 & & \\
Continuity Correction ${ }^{\mathrm{b}}$ & .618 & 1 & .432 & .332 & \\
Likelihood Ratio & .891 & 1 & .345 & .216 \\
Fisher's Exact Test & .885 & 1 & .347 & & \\
Linear-by-Linear & 162 & & & & \\
Association & & & & & \\
N of Valid Cases & & & & & \\
\hline
\end{tabular}

a. 0 cells $(.0 \%)$ have expected count less than 5 . The minimum expected count is 39.00 .

b. Computed only for a $2 \times 2$ table

Building on the above matrix, dichotomous variables were created to represent each of the quadrants to examine different outcomes for firms. Table 14 shows the correlation matrix with the four quadrant variables. To analyze further, the different firm types were used in a regression model predicting GEP.

Table 15 shows the regression results using the quadrants to predict GEP. In model 2, both "Agent of Change" and "Green Competent" significantly predict GEP $(p<.001)$. The model 
has an adjusted R-square of .612 and a significant R-square change. The "exploiter" variable was the excluded variable in the regression output.

The classification of firms was found to significantly predict network density as shown in table 16. The quadrant of "Green Competent" firms had a negative and significant relationship with network density $(\mathrm{p}<.05)$. This explains that firms who are not "green competent" are also those who have to manage highly dense networks (many subsidiaries). This finding is in line with the theoretical argument of presented in RQ\#2 that increased network density is likely to challenge GEP. 
TABLE 14: Correlation Matrix: Four Quadrants

\begin{tabular}{|c|c|c|c|c|c|c|c|c|c|c|}
\hline & $\begin{array}{l}\text { Exploiter } \\
\text { Quadrant I }\end{array}$ & $\begin{array}{c}\text { Compliant } \\
\text { Quadrant } \\
\text { II }\end{array}$ & $\begin{array}{l}\text { Agent of } \\
\text { Change } \\
\text { Quadrant } \\
\text { III }\end{array}$ & $\begin{array}{c}\text { Green } \\
\text { Competent } \\
\text { Quadrant } \\
\text { IV }\end{array}$ & $\begin{array}{c}\text { Mission } \\
\text { statements }\end{array}$ & $\begin{array}{c}\text { Environmental } \\
\text { Reputation }\end{array}$ & $\begin{array}{l}\text { Green Policy } \\
\text { Management }\end{array}$ & $\begin{array}{l}\text { Geographic } \\
\text { Distance } \\
\text { KM }\end{array}$ & $\begin{array}{l}\text { Revenue } \\
2010 \log \end{array}$ & ROS 2010 \\
\hline $\begin{array}{l}\text { Exploiter } \\
\text { Quadrant I }\end{array}$ & 1 & & & & & & & & & \\
\hline \multirow{3}{*}{$\begin{array}{l}\text { Compliant } \\
\text { Quadrant II } \\
\text { Agent of } \\
\text { Change } \\
\text { Quadrant III } \\
\text { Green } \\
\text { Competent } \\
\text { Quadrant IV }\end{array}$} & $-.338^{* *}$ & & & & & & & & & \\
\hline & $-.344^{* *}$ & $-.287^{* *}$ & & & & & & & & \\
\hline & $-.383^{* *}$ & $-.320^{* *}$ & $-.325^{* *}$ & & & & & & & \\
\hline \multirow{3}{*}{$\begin{array}{l}\text { Mission } \\
\text { statements } \\
\text { Environmenta } \\
\text { 1 Reputation } \\
\text { Green Policy } \\
\text { Management }\end{array}$} & .126 & .021 & -.003 & -.150 & & & & & & \\
\hline & -.033 & $-.192^{*}$ & $.209^{* *}$ & .016 & .059 & & & & & \\
\hline & -.034 & $-.219^{* *}$ & $.235^{* *}$ & .017 & .051 & $.552^{* *}$ & & & & \\
\hline \multirow{3}{*}{$\begin{array}{l}\text { Geographic } \\
\text { Distance KM } \\
\text { Revenue } 2010 \\
\text { log } \\
\text { ROS } 2010\end{array}$} & .138 & $-.258^{* *}$ & $.216^{* *}$ & -.094 & -.152 & .095 & .070 & & & \\
\hline & -.016 & -.053 & .136 & -.062 & $.239^{* *}$ & $.379^{* *}$ & $.342^{* *}$ & $-.225^{* *}$ & & \\
\hline & -.015 & .006 & -.081 & .087 & .004 & .074 & .056 & .096 & -.069 & \\
\hline \multirow{3}{*}{$\begin{array}{l}\text { Net } 2010 \\
\text { Income/Loss } \\
\text { (Loss) } \\
\text { Firm Size } \\
\text { (Employees } \\
2010) \\
\text { Network } \\
\text { Density }\end{array}$} & -.044 & -.009 & .077 & -.020 & $.241^{* *}$ & $.325^{* *}$ & $.184^{*}$ & -.092 & $.646^{* *}$ & $.338^{* *}$ \\
\hline & .017 & -.144 & .146 & -.022 & .007 & $.444^{* *}$ & $.363^{* *}$ & .087 & $.684^{* *}$ & -.065 \\
\hline & .079 & $-.179^{*}$ & $.181^{*}$ & -.077 & -.003 & $.318^{* *}$ & $.246^{* *}$ & $.377^{* *}$ & $.209^{* *}$ & -.107 \\
\hline
\end{tabular}


TABLE 15: Post Hoc Regression Analysis using four Quadrants to Predict GEP

\begin{tabular}{|c|c|c|}
\hline $\mathrm{N}=175$ & M1 & M2 \\
\hline Unstandardized Coefficients & Control & 4 Quadrants $\rightarrow$ GEP \\
\hline Constant & $\begin{array}{l}19.358^{*} \\
(7.627)\end{array}$ & $\begin{array}{c}8.163 \\
(6.388)\end{array}$ \\
\hline Firm Performance (ROS) & $\begin{array}{l}7.166^{* * *} \\
(1.922)\end{array}$ & $\begin{array}{l}5.235^{* *} \\
(1.513)\end{array}$ \\
\hline Firm Size (Employee log) & $\begin{array}{l}.091 \\
(.224)\end{array}$ & $\begin{array}{l}.140 \\
(.175)\end{array}$ \\
\hline SIC 2000 \& 2100: Food / Tobacco Products & $\begin{array}{l}-33.208 * * * \\
(5.986)\end{array}$ & $\begin{array}{l}-18.444 * * * \\
(4.837)\end{array}$ \\
\hline $\begin{array}{l}\text { SIC } 2200 \text { to 2500: (Textile Mill Products/Apparel/ } \\
\text { Lumber and Wood / Furniture and Fixtures) }\end{array}$ & $\begin{array}{l}-2.390 \\
(9.546)\end{array}$ & $\begin{array}{c}.336 \\
(7.436)\end{array}$ \\
\hline SIC 2600 and 2700: ( Paper/ Printing, Publishing) & $\begin{array}{c}-21.945^{*} \\
(8.603) \\
\end{array}$ & $\begin{array}{c}-16.680^{*} \\
(6.699)\end{array}$ \\
\hline $\begin{array}{l}\text { SIC3000 to 3400: Rubber / Stone, Clay, Glass / } \\
\text { Primary Metal / Fabricated Metal Products }\end{array}$ & $\begin{array}{l}-8.951 \\
(7.575)\end{array}$ & $\begin{array}{l}-1.940 \\
(5.935)\end{array}$ \\
\hline SIC 3500 Industrial / Computer Equipment & $\begin{array}{l}11.679^{*} \\
(5.822)\end{array}$ & $\begin{array}{c}5.167 \\
(4.564)\end{array}$ \\
\hline SIC 3600: 3600 - Electronic Equipment & $\begin{array}{l}16.701^{*} \\
(6.413)\end{array}$ & $\begin{array}{l}8.748+ \\
(5.079)\end{array}$ \\
\hline SIC3700 Transportation Equipment & $\begin{array}{c}-.751 \\
(6.678)\end{array}$ & $\begin{array}{c}.272 \\
(5.194)\end{array}$ \\
\hline $\begin{array}{l}\text { SIC } 3800 \& 3900: \text { Instruments /Miscellaneous } \\
\text { manufacturing }\end{array}$ & $\begin{array}{l}19.115^{*} \\
(6.573)\end{array}$ & $\begin{array}{l}9.534+ \\
(5.182)\end{array}$ \\
\hline \multicolumn{3}{|l|}{ Exploiter Quadrant } \\
\hline Compliant Quadrant & & $\begin{array}{c}2.189 \\
(3.886)\end{array}$ \\
\hline Agent of Change Quadrant & & $\begin{array}{l}35.066^{* * *} \\
(4.209)\end{array}$ \\
\hline Green Competent Quadrant & & $\begin{array}{l}32.111 * * * \\
(3.994)\end{array}$ \\
\hline R-Square & .387 & .641 \\
\hline Adjusted R & .350 & .612 \\
\hline R-Square change & $.387^{* * *}$ & $.254^{* * *}$ \\
\hline
\end{tabular}


TABLE 16: Post Hoc Regression Analysis using four Quadrants to Predict Network Density

\begin{tabular}{|c|c|c|}
\hline $\mathrm{N}=162$ & M1 & M2 \\
\hline Unstandardized Coefficients & Control & 4 Quadrants $\rightarrow$ Density \\
\hline Constant & $\begin{array}{c}1.953 \\
(6.140)\end{array}$ & $\begin{array}{c}7.046 \\
(6.514)\end{array}$ \\
\hline Firm Performance (ROS) & $\begin{array}{l}-.186 \\
(.178)\end{array}$ & $\begin{array}{l}-.140 \\
(.177)\end{array}$ \\
\hline Firm Size (Employee log) & $\begin{array}{c}11.110^{* * *} \\
(1.590)\end{array}$ & $\begin{array}{l}10.948 \\
(1.608)\end{array}$ \\
\hline SIC 2000 \& 2100: Food / Tobacco Products & $\begin{array}{c}-14.173 * * \\
(4.868)\end{array}$ & $\begin{array}{r}-16.519 \\
(5.080)\end{array}$ \\
\hline $\begin{array}{l}\text { SIC } 2200 \text { to 2500: (Textile Mill } \\
\text { Products/Apparel/ Lumber and Wood / Furniture }\end{array}$ & $\begin{array}{c}-15.714+ \\
(7.979)\end{array}$ & $\begin{array}{l}-18.658 \\
(7.954)\end{array}$ \\
\hline SIC 2600 and 2700: ( Paper/ Printing, Publishing) & $\begin{array}{l}-1.126 \\
(7.104)\end{array}$ & $\begin{array}{l}-2.610 \\
(7.090)\end{array}$ \\
\hline $\begin{array}{l}\text { SIC3000 to 3400: Rubber / Stone, Clay, Glass / } \\
\text { Primary Metal / Fabricated Metal Products }\end{array}$ & $\begin{array}{l}-5.930 \\
(6.148)\end{array}$ & $\begin{array}{l}-6.275 \\
(6.152)\end{array}$ \\
\hline SIC 3500 Industrial / Computer Equipment & $\begin{array}{l}-4.848 \\
(4.726)\end{array}$ & $\begin{array}{l}-4.344 \\
(4.756)\end{array}$ \\
\hline SIC 3600: 3600 - Electronic Equipment & $\begin{array}{l}-7.130 \\
(5.070)\end{array}$ & $\begin{array}{c}-8.642 \\
(5.176)\end{array}$ \\
\hline SIC3700 Transportation Equipment & $\begin{array}{l}-21.316^{* * *} \\
(5.629)\end{array}$ & $\begin{array}{l}-19.914 * * * \\
(5.578)\end{array}$ \\
\hline $\begin{array}{l}\text { SIC } 3800 \text { \& 3900: Instruments /Miscellaneous } \\
\text { manufacturing }\end{array}$ & $\begin{array}{l}-6.747 \\
(5.289)\end{array}$ & $\begin{array}{l}-4.280 \\
(5.400)\end{array}$ \\
\hline \multicolumn{3}{|l|}{ Exploiter Quadrant } \\
\hline Compliant Quadrant & & $\begin{array}{l}-7.495+ \\
(4.000)\end{array}$ \\
\hline Agent of Change Quadrant & & $\begin{array}{l}-1.985 \\
(4.567)\end{array}$ \\
\hline Green Competent Quadrant & & $\begin{array}{l}-9.802^{*} \\
(4.364)\end{array}$ \\
\hline R-Square & .310 & .342 \\
\hline Adjusted R & .265 & .285 \\
\hline R-Square change & .310 & $.032+$ \\
\hline
\end{tabular}




\section{Statistical Hierarchical Clustering}

The above segmentation has produced four quadrants/firm types based on a conceptual yet arbitrary method that used the median scores for GEP and environmental institutional score variables to form the segments. The next section will present the results of the hierarchical cluster analysis used to classify firms according to the following key variables examined in this study: GEP, green policy management, and all network dimensions (density, geographic distance, environmental institutional score). Using the Ward's approach (Hair \& Black, 2000; Saunders, 1993), the squared Euclidean distances are used to form clusters. The variables were standardized to form z- scores. The agglomeration schedule shown in Appendix 4 revealed there were actually six clusters. The number of firms in each cluster is shown in table 17. Clusters 2 and 5 are the largest clusters in terms of number of firms. A one sample t- test was conducted to check that there are significant differences between these six sectors $(\mathrm{p}<.001)$ as shown in Table 18. For a listing of firms according to cluster membership, see Appendix 5.

TABLE 17

\begin{tabular}{|c|c|c|c|c|c|}
\hline & & Frequency & Percent & Valid Percent & $\begin{array}{c}\text { Cumulative } \\
\text { Percent }\end{array}$ \\
\hline \multirow[t]{7}{*}{ Valid } & 1 & 27 & 14.7 & 16.7 & 16.7 \\
\hline & 2 & 41 & 22.3 & 25.3 & 42.0 \\
\hline & 3 & 14 & 7.6 & 8.6 & 50.6 \\
\hline & 4 & 25 & 13.6 & 15.4 & 66.0 \\
\hline & 5 & 44 & 23.9 & 27.2 & 93.2 \\
\hline & 6 & 11 & 6.0 & 6.8 & 100.0 \\
\hline & Total & 162 & 88.0 & 100.0 & \\
\hline \multirow[t]{2}{*}{ Missing } & System & 22 & 12.0 & & \\
\hline & & 184 & 100.0 & & \\
\hline
\end{tabular}


TABLE 18

\begin{tabular}{|c|c|c|c|c|c|c|}
\hline & \multicolumn{9}{|c|}{ One-Sample Test } \\
\cline { 2 - 7 } & & & & & \multicolumn{2}{c|}{$\begin{array}{c}95 \% \text { Confidence Interval } \\
\text { of the Difference }\end{array}$} \\
\cline { 4 - 8 } & $\mathrm{t}$ & Df & Sig. (2-tailed) & Mean Difference & Lower & Upper \\
\hline CLU6_3 Ward Method & 25.728 & 161 & .000 & 3.315 & 3.06 & 3.57 \\
\hline
\end{tabular}

After the formation of these clusters, ANOVA was conducted to examine the impact of such a classification on key variables: including GEP, green policy management, environmental institutional network score, density, geographic distance, and firm size.

Using the cluster formed from the hierarchical cluster analysis, the below Table 19 shows the results of the ANOVA tables. All models show there is a significant difference between the groups $(\mathrm{p}<.001)$. This provides evidence that each of the cluster is significantly different from at least one other cluster on each of the below variables. 
TABLE 19

ANOVA

\begin{tabular}{|c|c|c|c|c|c|c|}
\hline & & Sum of Squares & $\mathrm{df}$ & Mean Square & $\mathrm{F}$ & Sig. \\
\hline Green Policies & $\begin{array}{l}\text { Between Groups } \\
\text { Within Groups } \\
\text { Total }\end{array}$ & $\begin{array}{l}39389.218 \\
38156.688 \\
77545.905\end{array}$ & $\begin{array}{c}5 \\
156 \\
161\end{array}$ & $\begin{array}{l}7877.844 \\
244.594\end{array}$ & 32.208 & .000 \\
\hline GEP & $\begin{array}{l}\text { Between Groups } \\
\text { Within Groups } \\
\text { Total }\end{array}$ & $\begin{array}{c}78083.567 \\
51466.308 \\
129549.875 \\
\end{array}$ & $\begin{array}{c}5 \\
156 \\
161\end{array}$ & $\begin{array}{c}15616.713 \\
329.912\end{array}$ & 47.336 & .000 \\
\hline Density & $\begin{array}{l}\text { Between Groups } \\
\text { Within Groups } \\
\text { Total }\end{array}$ & $\begin{array}{l}45607.466 \\
24871.232 \\
70478.698 \\
\end{array}$ & $\begin{array}{c}5 \\
156 \\
161\end{array}$ & $\begin{array}{c}9121.493 \\
159.431\end{array}$ & 57.213 & .000 \\
\hline Geographic Distance KM & $\begin{array}{l}\text { Between Groups } \\
\text { Within Groups } \\
\text { Total }\end{array}$ & $\begin{array}{l}3.337 \mathrm{E} 8 \\
1.436 \mathrm{E} 8 \\
4.773 \mathrm{E} 8\end{array}$ & $\begin{array}{c}5 \\
156 \\
161\end{array}$ & $\begin{array}{c}6.674 \mathrm{E} 7 \\
920647.970\end{array}$ & 72.487 & .000 \\
\hline $\begin{array}{l}\text { Environmental institutional } \\
\text { network score }\end{array}$ & $\begin{array}{l}\text { Between Groups } \\
\text { Within Groups } \\
\text { Total }\end{array}$ & $\begin{array}{c}637.344 \\
1396.200 \\
2033.544\end{array}$ & $\begin{array}{c}5 \\
156 \\
161\end{array}$ & $\begin{array}{c}127.469 \\
8.950\end{array}$ & 14.242 & .000 \\
\hline Firm size ( log of employee) & $\begin{array}{l}\text { Between Groups } \\
\text { Within Groups } \\
\text { Total }\end{array}$ & $\begin{array}{c}30.375 \\
106.941 \\
137.316\end{array}$ & $\begin{array}{c}5 \\
154 \\
159\end{array}$ & $\begin{array}{c}6.075 \\
.694\end{array}$ & 8.748 & .000 \\
\hline
\end{tabular}

It is clear from the above table 19 that there was a significant difference between clusters in all of the models. The next step needed was to find out which group clusters were different from one another with respect to the different variables. Tables 20a-20e show the post hoc analysis using the Duncan test (Winer, Michels \& Brown, 1991) to determine the differences between mean sets for each key variable. The Duncan test reports means in separate columns, indicating they are statistically different from other means in other columns. Those mean scores found in the same column indicate that all clusters in those columns are not statistically different from one another. Below is a detailed discussion of the results of the Duncan test for each of the variables based on the 6 clusters. It is on the basis of the 
following output that the upcoming cross variable definition of each of the clusters is determined.

Green Policy Management: In classifying the sample of firms according to their green policy management scores, there are four main statistically distinct categories for this variable based on their mean scores. According to table 20a, Cluster 5 lies in the first column characterized by having a "very low" mean score. Cluster 6 lies in the "low" mean score column. The third column characterized by having a "medium" mean score contains clusters 2,3 , and 1 . Finally cluster 4 lies in column 4 , which has the "high" mean score.

TABLE 20a

Green Policies Management

Duncan,
\begin{tabular}{|c|c|c|c|c|c|}
\hline $\begin{array}{l}\text { CLU6_3 } \\
\text { Ward } \\
\text { Method }\end{array}$ & $\mathrm{N}$ & 1 & 2 & 3 & 4 \\
\hline 5 & 44 & 24.4175 & & & \\
6 & 11 & & 36.1664 & & \\
2 & 41 & & & 48.5529 & \\
3 & 14 & & & 49.1414 & \\
1 & 27 & & & 54.4533 & \\
4 & 25 & & & & 70.9128 \\
Sig. & & 1.000 & 1.000 & .253 & 1.000 \\
\hline
\end{tabular}

Means for groups in homogeneous subsets are displayed.

a. Uses Harmonic Mean Sample Size $=20.943$.

b. The group sizes are unequal. The harmonic mean of the group sizes is used. Type I error levels are not guaranteed.

GEP: In classifying the sample of firms according to their global environmental performance scores, there are four main statistically distinct categories for this variable based on their mean scores. According to table 21b, Clusters 2 and 6 lie in the first column characterized by 
having "very low" mean scores. Cluster 5 lies in the "low" mean score column. The third column is characterized by having a "medium" mean score and contains clusters 3 and 4 . Finally cluster 1 lies in column 4 which has a "high" mean score.

TABLE $20 b$

\section{GEP}

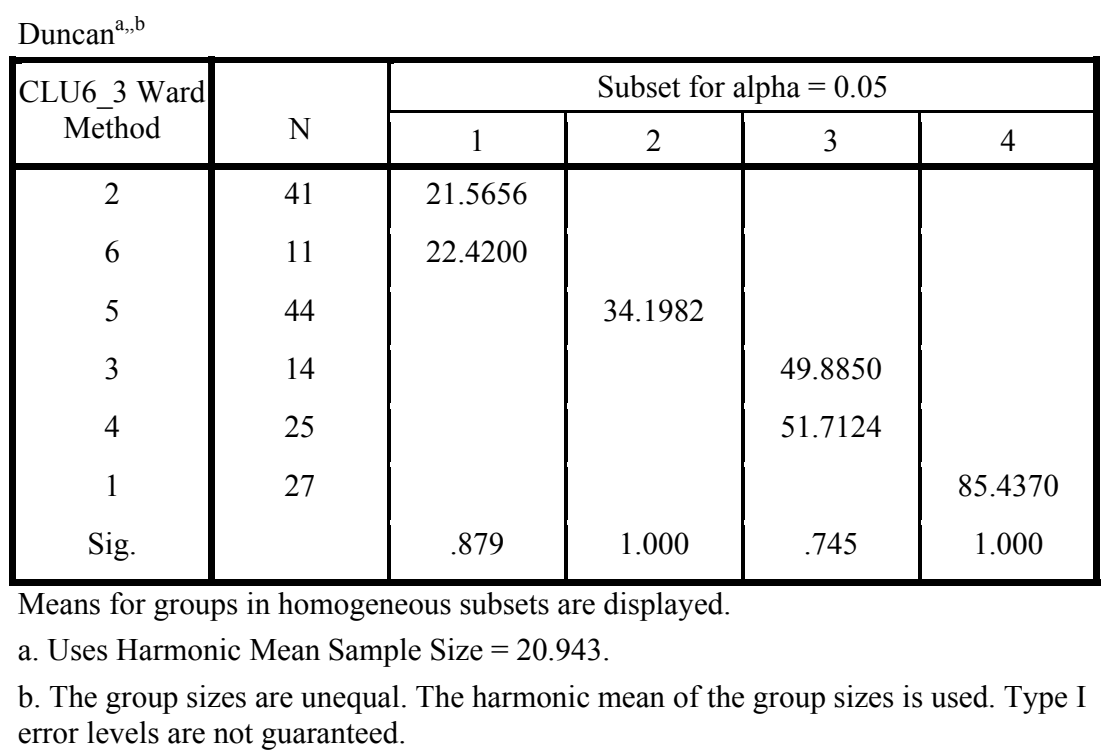

Network Density: In classifying the sample of firms according to their network density, there are four main statistically distinct categories for this variable based on their mean scores. According to table 20c, Clusters 3 and 6 lie in the first column characterized by having "very low" mean scores. Cluster 2 lies in the "low" mean score column. The third column characterized by having a "medium" mean score contains clusters 1 and 5 . Finally cluster 4 lies in column 4 which has a "high" mean score. 
TABLE 20c

Density

Duncan $^{\mathrm{a}, \mathrm{b}}$,
\begin{tabular}{|c|c|c|c|c|c|}
\hline $\begin{array}{c}\text { CLU6_3 } \\
\text { Ward } \\
\text { Method }\end{array}$ & $\mathrm{N}$ & 1 & 2 & 3 & 4 \\
\hline & 11 & 4.00 & & & \\
3 & 14 & 7.93 & & & \\
2 & 41 & & 22.05 & & \\
1 & 27 & & & 30.93 & \\
5 & 44 & & & 30.95 & \\
4 & 25 & & & & 63.88 \\
Sig. & & .316 & 1.000 & .994 & 1.000 \\
\hline
\end{tabular}

Means for groups in homogeneous subsets are displayed.

a. Uses Harmonic Mean Sample Size $=20.943$.

b. The group sizes are unequal. The harmonic mean of the group sizes is used.

Type I error levels are not guaranteed.

Network Geographic Distance: In classifying the sample of firms according to their geographic distance, there are four main statistically distinct categories for this variable based on their mean scores. According to table 20d, Cluster 6 lies in the first column characterized by having "very low" mean scores. Cluster 3 lies in the "low" mean score column. The third column is characterized by having a "medium" mean score and contains clusters 2, 4, and 5. Finally cluster 1 lies in column 4 which has a "high" mean score. It is important to note that there is no distinct difference between clusters 2 and 4 found in columns 3 and 4. 
TABLE 20d

Geographic distance KM

\begin{tabular}{|c|c|c|c|c|c|}
\hline \multirow{2}{*}{$\begin{array}{l}\text { CLU6_3 } \\
\text { Ward } \\
\text { Method }\end{array}$} & \multirow[b]{2}{*}{$\mathrm{N}$} & \multicolumn{4}{|c|}{ Subset for alpha $=0.05$} \\
\hline & & 1 & 2 & 3 & 4 \\
\hline 6 & 11 & 3.38 & & & \\
\hline 3 & 14 & & 5.37 & & \\
\hline 5 & 44 & & & 7.90 & \\
\hline 4 & 25 & & & 8.14 & 8.14 \\
\hline 2 & 41 & & & 8.45 & 8.45 \\
\hline 1 & 27 & & & & 8.61 \\
\hline Sig. & & 1.000 & 1.000 & .077 & .139 \\
\hline
\end{tabular}

Means for groups in homogeneous subsets are displayed.

a. Uses Harmonic Mean Sample Size $=20.943$.

b. The group sizes are unequal. The harmonic mean of the group sizes is used. Type I error levels are not guaranteed.

Network Environmental Institutional Score: In classifying the sample of firms according to their network's environmental institutional score, there are three main statistically distinct categories for this variable based on their mean scores. According to table 20e, Clusters 6, 2, 1 , and 4 lie in the first column characterized by having "very low" mean scores. Cluster 5 lies in the "low" mean score column. The third column contains cluster 3, which has the highest mean score. 
TABLE 20e

Environmental Institutional network score Duncan $^{\mathrm{a}, \mathrm{b}}$

\begin{tabular}{|c|c|c|c|c|}
\hline \multirow{2}{*}{$\begin{array}{c}\text { CLU6_3 } \\
\text { Ward } \\
\text { Method }\end{array}$} & $\mathrm{N}$ & 1 & 2 & 3 \\
\hline & 11 & 77.8560 & & \\
\hline 6 & 41 & 78.0177 & & \\
2 & 27 & 78.3054 & & \\
1 & 25 & 78.5478 & & \\
4 & 44 & & 81.4000 & \\
5 & 14 & & & 84.1183 \\
3 & & .503 & 1.000 & 1.000 \\
\hline Sig. & & & & \\
\hline
\end{tabular}

Means for groups in homogeneous subsets are displayed.

a. Uses Harmonic Mean Sample Size $=20.943$.

b. The group sizes are unequal. The harmonic mean of the group sizes is used. Type I error levels are not guaranteed.

Based on the above analyses, the next step summarizes the above findings in order to create a profile for each cluster based on the investigated dimensions. Table 21 summarizes the data for the 6 clusters. This is followed by a description of each cluster in terms of how it scores on the variables of green policies, GEP, density, geographic distance, and environmental institutional network score. Overall, Clusters 2 and 5 are the largest clusters in terms of number of firms. Clusters 1 and 4 have high and medium GEP respectively. Clusters 2 and 6 have the poorest GEP. 
TABLE 21: Summary of Hierarchical Cluster Classification

\begin{tabular}{|c|c|c|c|c|c|c|c|c|c|c|c|c|c|c|c|c|c|c|c|c|c|c|c|c|}
\hline & \multicolumn{4}{|c|}{ Cluster1 } & \multicolumn{4}{|c|}{ Cluster2 } & \multicolumn{4}{|c|}{ Cluster 3} & \multicolumn{4}{|c|}{ Cluster 4} & \multicolumn{4}{|c|}{ Cluster 5} & \multicolumn{4}{|c|}{ Cluster 6} \\
\hline & High & medium & low & verylow & High & medium & low & verylow & high & medium & low & verylow & high & medium & low & verylow & high & medium & low & verylow & high & medium & low & verylow \\
\hline Green policies & & 1 & & & & 1 & & & & 1 & & & 1 & & & & & & & 1 & & & 1 & \\
\hline GEP & 1 & & & & & & & 1 & & 1 & & & & 1 & & & & & 1 & & & & & 1 \\
\hline Density & & 1 & & & & & 1 & & & & & 1 & 1 & & & & & 1 & & & & & & 1 \\
\hline Geographic Distance KM & 1 & & & & & 1 & & & & & 1 & & & 1 & & & & 1 & & & & & & 1 \\
\hline $\begin{array}{l}\text { Environmental Institutional } \\
\text { networkscore }\end{array}$ & & & & 1 & & & & 1 & 1 & & & & & & & 1 & & 1 & & & & & & 1 \\
\hline
\end{tabular}


Cluster 1 is characterized by having a medium green policy score, high GEP, medium density, high geographic distance, and very low environmental institutional network score.

Cluster 2 is characterized by having a medium green policy score, very low GEP, low density, medium geographic distance, and very low environmental institutional network score.

Cluster 3 is characterized by having a medium green policy score, medium GEP, very low density, low geographic distance, and very high environmental institutional network score.

Cluster 4 is characterized by having a high green policy score, medium GEP, high density, medium geographic distance, and very low environmental institutional network score.

Cluster 5 is characterized by having a very low green policy score, low GEP, medium density, medium geographic distance, and medium environmental institutional network score.

Cluster $\mathbf{6}$ is characterized by having a low green policy score, very low GEP, very low density, very low geographic distance, and very low environmental institutional network score. 


\section{Discussion and Contributions of Post Hoc Segmentation Analysis}

The above segmentation analysis has sought to provide insights into the relationship between MNC environmental performance/management and dimensions of their subsidiary network. The $2 \times 2$ matrix has sought to classify firms on environmental performance and institutional contexts of their subsidiaries using the underlying argument that firms' actions can be impacted by the environmental institutional contexts of their host markets. From this analysis, a typology of firms was created and used to predict GEP and density. The results show most promise for the "agent of change" and "green competent" firm types. From the analysis based on the $2 \times 2$ matrix, firms classified as "agents of change" firms were found to have the highest green policy management score. This shows that firms are capable of being environmentally compliant even when they operate in host markets that have lesser concern for the environment. Fergus and Rowney (2005) explain that organizations have a responsibility to not only comply with society's norms, but also take an active role in changing them, possibly through activities such as building environmental awareness. Kwok and Tadesse (2006) also advocate the role of MNCs as agents of change and show how they can influence host market institutions over time.

In the hierarchical clustering analysis, the grouping of firms was based on a non-arbitrary method which took into account various network and firm environmental measures, which yielded six clusters of firms when these key variables were incorporated. So while the above $2 \times 2$ matrix specifically focused on the relationship between two variables to build a 
typology of firms, the hierarchical clustering analysis showed there were actually six clusters when the five key variables were incorporated.

Based on the above analysis, cluster 1 had firms with the highest GEP, while clusters 5 and 6 contain the poorest performers on GEP and green policy management. Four of the six clusters operate within very low environmental institutional network contexts. Interestingly, cluster 2 has effective green policy management but scores lowest in actual GEP. Cluster 4 constitutes firms that operate highly dense networks but still manage to have medium/high GEP and green policy management.

The listing of firms according to cluster membership provided in the appendix section of this study can be used to allow investors and scholars to develop insights into the (1) identity of firms leading GEP and green policy management and also those facing harder challenges within consideration of their subsidiary network structure dimensions. This can also help stakeholders distinguish (2) who is actually performing in the right direction versus those who have put policies in place but have not performed.

From the post hoc, classification of firms on the dimensions of GEP and network environment institutional network score, this dissertation provides a typology that scholars can build on which classifies firms as: exploiters, compliers, agents of change or green competent. Using this classification, regression results showed agents of change to have a positive significant relationship with green policy management and GEP. The segment of "agents of change" is of specific interest indeed. Further studies can examine closer who are 
these companies and what unique capabilities/characteristics are behind making this segment play the role of leaders of change in their respective markets. What will it take for them to become "green competent"? The findings from this analysis also showed that firms who are "green compliant" were likely to have less dense networks, which supports the main underlying argument that fewer units will result in lesser challenges for GEP implementation.

The post hoc, hierarchal clustering of firms revealed there were 6 clusters of firms based on the examination of their environmental performance, green policy management and network dimensions. The analysis reveals that firms in cluster 1 and 4 have the highest GEP, while cluster 5 and 6 contains the poorest performers on GEP and green policy management. Interestingly, cluster 5 has the highest absolute number of firms (44 MNCs) and it is characterized by having very low/low Green Management Policy/GEP scores respectively. Future research can focus on investigating this segment alone to determine how they score on verbal environmental commitment and also environmental reputation, which will help scholars determine if it pays to greenwash.

Four of the six clusters operate within very low environmental institutional contexts. Interestingly, firms in clusters $1 \& 4$ all operated in a network with a low pro-environmental institutional score, but still had high/medium GEP or green policy management. Meanwhile, cluster 3 reflects firms that operate in high pro-environmental institutional contexts that have medium GEP and Green policy management. The findings from this cluster analysis support the variation that exists between firms on elements of ecological performance and foreign investment locations. This argument is supported by the earlier work of Rugman and 
Verbeke (1987) and Payne and Raiborn (2001) explain that firms' behaviors can range from compliance with the law all the way to making environmental performance its distinct competitive advantage. This is also in line with the previous discussion of main results about firms taking the upper hand of managing their footprints voluntarily aside from contextual host market pressures.

Observations from the clusters formed indicate a correlation between green policy management and GEP, such that when GEP is high/medium, so is green policy management. From the cluster analysis, we can observe that the highest performing clusters in terms of GEP and green policy management (cluster $1 \& 4$ ) both had medium/high density and geographic dispersion, although a low Environmental Institutional Network Score. A takeout from this observation is we are finding firms that have kept policy and GEP at the same level reflecting standardization of operations policies that coincides with actual performance, and most interesting they have done so despite operating in low pro-environmental institutional host markets.

From the cluster analysis we can also observe a category of firms whereby green policy management level does not match the level of GEP. Cluster 2 presents an interesting scenario where firms have medium green policy management but very low GEP. Perhaps it is among these sets of firms where future studies should investigate factors that challenge the implementation from policy to performance. Focusing on such a segment, future studies can investigate what headquarters subsidiary and contextual level factors are behind the 
discrepancies between policy and performance. This study has focused on network dimensions but there could be other factors behind such discrepancies.

Overall, from this post hoc classification analysis, a typology of firms can be created which investigates the relationship between MNCs GEP scores and subsidiary network dimensions. Extension papers can study how this typology can lead to a deeper understanding of each segment. This is not limited to only identifying who these firms are in terms of their profile, competencies, and leadership. In addition this, the presented classifications can be used to predict other strategic outcomes, including identification of industry trend setters in the CSR/CEM platform.

\section{DISSERTATION SUMMARY}

This dissertation has sought to investigate the challenges MNCs face when seeking to optimize their global environmental performance. It first examined the core elements of CEM with HQ using informal and formal mechanisms to control environmental outcomes. The paper presented a comprehensive VMPR approach which investigated firms' verbal environmental commitment, management policy, actual environmental performance and finally environmental reputation. It investigated a combination of key constructs that constitute corporate environmental management (CEM) in a single study. It then focused on the challenges brought about by the MNC's network dimensions, drawing from network theory, corporate environmental management, and HQ-Subsidiary management literatures. 
The potential contributions of this study can be categorized under theoretical, empirical, and managerial aspects.

Theoretical Contributions: The paper aims to contribute to CEM and CEM implementation focusing on the MNC-subsidiary network management literatures. While prior research has focused on the relationship between MNC subsidiary network structure and financial performance (Markides \& Williamson, 1996; Mauri, 2009, Pitts, 1977), or the relationship between environmental performance and financial performance (Dowell, Hart \& Yeung, 2000; Bansal \& Clelland, 2004; Nakao, et al. 2007), this study sought to respond to the call for research that investigates the impact of $\mathrm{MNC}$ international networks of subsidiaries on environmental practices (Rodriguez, Siegel, Hillman, \& Eden, 2006). In addition, this study introduced a new construct, "Environmental Institutional Diversity", calling for the importance of investigating environmental institutional variation and not only the difference between home and host based institutions. Finally, it created a conceptual typology of firms based on their subsidiaries' host institutional contexts and MNC GEP presented in a two x two matrix describing firms as either compliant, exploiter, agent of change or green competent.

Empirical Contributions: The unit of analysis being the MNC's subsidiary network is likely to reveal value-adding insights about firm behavior, which may not be visible when we are analyzing either HQ or individual subsidiaries (Gruber, Heinemann, Brettel \& Hungeling, 2010; Miller, 1981). The majority of research in the HQ-subsidiary domain has taken a onesided perspective, arguing either the HQ or subsidiary perspectives (Birkinshaw, 2001; Doz 
\& Prahalad, 1993; Kaufmann \& Roessing, 2005, Schotter \& Beamish, 2005), while this paper focus on the network, the systemic level of analysis, to analyze behavior of the organization (Gupta \& Govindarajan, 2000; Ghoshal \& Bartlett, 1990). While earlier studies have used single industry survey data to gauge the environmental performance of firms, this study uses a continuous variable reflecting quantified assessment of companies' actual environmental footprint across multiple sectors within manufacturing. The data provided for the analysis of this study combines both qualitative and quantitative measures, drawing from a number of prominent data providers in the area of CSR/environmental management (Trucost, MSCI ESG (former KLD data providers), Corporate Register) using a relatively "new" database. The paper also develops a new approach to measuring "geographic dispersion" which is driven by the network complexity lens. Finally, the study uses hierarchical cluster analysis to segment MNCs on dimensions of environmental management/performance and network dimensions. Through such clustering, scholars can distinguish between who is actually performing in the right direction versus those who have put policies in place but have not performed. This also paves the road for future studies to dig deeper into the challenges these firms deal with as a result of the dimensions of their subsidiary networks.

Managerial Contributions: As MNCs expand into more diverse markets, creating more complex inter-organizational networks, it becomes very timely to better understand how their inter-organizational networks can challenge smooth CSR strategy implementation. Particular to global environmental practices and taking a strategic perspective, the increased trend of green consumerism and standardized environmental regulations across host market has made 
firms' efforts to globally standardize environmental practice an imperative to successful operations. Furthermore, from a stakeholder perspective, the MNC's global operations are today under even more scrutiny, and global social/environmental performance is a key component of their legitimacy in both home and host markets.

\section{Future Studies}

Overall, the value of the presented VMPR research model lies in its ability to examine not just environmental performance but a multitude of MNC strategies. This can include the adoption of best practices related to other timely firm priorities and not only that of environmental performance. Therefore, the VMPR is quite a comprehensive framework that is likely to be used by a number of scholars to investigate a number of phenomena.

The presented research model in this study is likely to lead to a number of future papers investigating different parts of the model. In addition, future versions of the paper can test the model investigating deeper key industries while combining industry reports and trends to understand how the model can explain industry specific phenomena. In addition, upcoming extensions of this study can incorporate internal unit diversity, which will be measured by the degree of variation at the subsidiary level in industry scope, using the Corporate Affiliations (Lexis Nexus) database. It would also be interesting to examine how network complexities can impact the relationship between GEP and environmental reputation, which is best carried out utilizing a longitudinal research design in order to capture the lag effect on reputation. 
Future extensions of this study can also examine the VMPR framework and research model using other units of analysis. For example, while subsidiary networks were the focus of this study, extensions can analyze phenomena at the team level examining the effectiveness of team structure.

\section{Limitations}

The study is limited by the unavailability of environmental performance data at the subsidiary level, which if incorporated, would yield a better specified model. To strengthen the causal relationship, time series analyses is likely to be useful. Therefore the use of a cross sectional dataset at this stage of the research can be seen as a limitation of the study. Furthermore when predicting reputation, lag effects need to be accounted for, which was restricted by data availability in this study. The dependent variable of Global Environmental Performance is available for the last 8 years, but needs to be purchased. A valid critique of the proposed research model would be the need to account for other factors to arrive at a better specified model. Some of these key constructs which may impact the relationships studied can include degree of decentralization of MNC and subsidiary level management variables.

Perhaps there may be other sources of complexity that overpower of impact of our three network diversity variables which are not measured in this study. These key elements, such as subsidiary level management/control systems, are best captured by survey data. A verbal commitment measure can also be captured by collecting other forms of corporate verbal communications which include $10 \mathrm{~K}$ reports as well as shareholder letters. In addition the 
content analysis done on the mission statement was analyzed by the primary investigator. Although it only involved the search of key words, it is only the result of a single rater. The accuracy of this measure could have benefited from conducting inter-rater reliability analysis and therefore may be acknowledged as a limitation in the study (Krippendorff, 2003).

While multiple regression analysis has been used by multiple scholars to analyze MNC networks, using network analysis (Ucinet) is likely to allow for capturing interunit phenomena. Furthermore, using structural equation modeling is also likely to increase the accuracy of the network diversity results which tested latent variables because of its effectiveness in decreasing measurement errors (Cheng, 2001). 


\section{LIST OF REFERENCES}

Abdelzaher, D. Schneper,W. \& Douglas Fernandez, W. (2012). The institutional drivers of transnational institutions: United nations global compact and the worldwide diffusion of corporate social responsibility, Working Paper.

Fraj-Andrés,E., Martínez-Salinas, E., \& Matute-Vallejo, J. (2009). Factors Affecting Corporate Environmental Strategy in Spanish Industrial Firms. Business Strategy and the Environment, 18, 500-514.

Aguilera-Caracuel, J., Aragón-Correa, J.A., \& Hurtado-Torres, N. E. (2011). Extending the literature on the environmental strategy of MNEs. Multinational Business Review, 299-310.

Aguilera-caracuel, J., Aragón-Correa, J. A., Hurtado-Torres, N. E. \& Rugman, A. M. (2012). The Effects of Institutional Distance and Headquarters' Financial Performance on the Generation of Environmental Standards in Multinational Companies. Journal of Business Ethics, 105 (4), 461-474.

Aiken, L. S., \& West, S. G. (1991). Multiple regression: Testing and interpreting interactions. Newbury Park, CA: Sage.

Akiyama, T. (2010). CSR and inter-organisational network management of corporate groups: Case study on environmental management of Sekisui House Corporation Group. Asian Business \& Management, 9 (2), 223-243.

Alexander, E. R. (1998). A structuration theory of interorganizational coordination: Cases in environmental management. International Journal of Organizational Analysis, 6 (4), 334-354.

Allen, P.M. (2001). A complex systems approach to learning in adaptive networks. International Journal of Innovation Management, 5 (2), 149-180.

Alter, C., \& Hage, J. (1993): Organizations Working Together. Newbury Park: Sage.

Amato, C. H., \& Amato, L. H. (2002). Corporate commitment to quality of life: Evidence from company mission statements. Journal of Marketing Theory and Practice, 1, 69-87.

Ambos, B., \& Schlegelmilch, B. B. (2007). Innovation and control in the multinational firm: A comparison of political and contingency approaches. Strategic Management Journal, 28 (5), 473-486.

Anderson, Philip, (1999). Complexity theory and organization science. Organization Science, 10 (3), 216-232. 
Andrews, R.N.L., Amaral, D., Darnall, D., Gallagher, D.R., Edwards, D., Hutson, A., D'Amore, C., Sun, L. \& Zhang, Y. (2003) Environmental Management Systems: Do They Improve Performance? The University of North Carolina: Chapel Hill, NC

Andrew, A., King, J., \& Myles, S. (2001). Are Aliens Green? Assessing Foreign Establishments' Environmental Conduct in the United States. Strategic Management Journal, $22 \quad$ (11), 1069-1085.

Andersson, U., Forsgren, M., \& Holm, U., (2001). Subsidiary embeddedness and competence development in MNCs -- A multi-level analysis. Organization Studies, 22 (6), 1013-23.

Aragon-Correa, J. A. (1998). Strategic proactivity and firm approach to the natural environment. Academy of Management Journal, 41, 556-567.

Aragon-Correa, J. \& Sharma, S. (2003). A Contingent Resource-Based View of Proactive Corporate Environmental Strategy. Academy of Management Review, 28 (1), 71-88.

Bandura, A. (1991). Social Cognitive Theory of Self-Regulation. Organizational behavior and human decision processes, 50, 248-287.

Bansal, P., \& Clelland, I. (2004). Talking Trash: Legitimacy, Impression Management, and Unsystematic Risk in the Context of the Natural Environment, Academy of Management Journal, 47 (1), 93-103.

Bansal, P., \& Kistruck, G. (2006). Seeing is (not) believing: managing the impressions of the firm's commitment to the natural environment. Journal of Business Ethics, 67,165-80.

Barin-Cruz, L., \& Pedrozo.E.A. (2009). Corporate social responsibility and green management: Relation between headquarters and subsidiary in multinational corporations. Management Decision, 47 (7), 1174-1199.

Barin Cruz, Luciano; Boehe, Dirk Michael. (2010). How do Leading Retail MNCs Leverage CSR Globally? Insights from Brazil. Journal of Business Ethics, 91 : 243-263.

Barney, J., \& Hesterly, W. 2012. Strategic Management and Competitive Advantage Fouth Edition: Concepts and Cases. Pearson Education Inc, NJ: Prentice Hall.

Bartlett, C., Ghoshal, S. (1989). Managing across borders: The transnational solution. Boston, MA: Harvard Business School Press.

Bartlett, C., Ghoshal, S. (1994). Changing the Role of Top Management: Beyond Strategy to Purpose. Harvard Business Review, 72 (6), 79-88. 
Bartkus, B. R \& Glassman, B. (2008). Do Firms Practice What They Preach? The Relationship Between Mission Statements and Stakeholder Management. Journal of Business Ethics, 83, 207-216.

Battram, A. (1996) The complexities: A Lexicon of Complexity, London, Local government management Board.

Behrend. T. S., Baker. B. A., \& Thompson, L.F. (2009). Effects of Pro-Environmental Recruiting Messages: The Role of Organizational Reputation. Journal of Business Psychology, 24, 341-350

Berman, S. L., Wicks, A.C. Kotha, S., \& Jones, T.M. (1999). Does Stakeholder Orientation Matter? The Relationship between Stakeholder Management Models and Firm Financial Performance. Academy of Management Journal, 42 (5), 488-506

Berrone, P., \& Gomez-Mejia, L.R. (2009). Environmental Performance and Executive Compensation: An Integrated Agency-Institutional Perspective. Academy of Management Journal, 52 (1), 103-126.

Birdsall, N., \& Wheeler, D. (1992). Trade policy and industrial pollution in Latin America: Where are the pollution havens? In P. Low (Ed.), International trade and the environment (World Bank Paper No. 159, 159-167). Washington, DC: World Bank.

Birkinshaw, J. M. (2001). Strategies for managing internal competition. California Management Review, 44, 21-38.

Bouquet, C., \& Birkinshaw, J., (2008). Weight versus voice: how foreign subsidiaries gain attention from corporate headquarters. Academy of Management Journal, 51(3), 577.

Birkinshaw, J., Hood, N., \& Jonsson, S., (1998). Building firm-specific advantages in multinational corporations: the role of subsidiary initiative. Strategic Management Journal, 19 (3), 221.

Birkinshaw, J., Hood, N., (1998). Multinational subsidiary evolution: Capability and charter change in foreign. Academy of Management Review; 23 (4), 773

Birkinshaw, J., \& Nobel, R. 1998. Innovation in multinational corporations: control and communication .Strategic Management Journal, 19 (5), 479.

Brass, D. J., Galaskiewicz,J., Henrich R. G., \& Tsai, W. (2004). Taking Stock of Networks and Organizations: A Multilevel Perspective. The Academy of Management Journal, 47 (6), 795-817.

Brodbeck, P. W. (2002). Complexity theory and organization procedure design. 
Business Process Management Journal, 8 (4), 377.

Brown, H.S., Derr, P., Renn, O., \& White, A.L. (1993). Corporate environmentalism in a global economy: Societal values in international technology transfer. Westport, CT: Quorum Books.

Business Wire (2010). Research and Markets: Understand The Factors That Are Driving The Growth Of Green Consumerism In The US with 2010 Report Green Consumers in the US.

Buysse, K., \& Verbeke, A. (2003). Proactive environmental strategies: A stakeholder management perspective. Strategic Management Journal, 24 (5), 453-470.

Behrend, T, S \& Baker, B. A. (2009). Effects of Pro-Environmental Recruiting Messages: The Role of Organizational Reputation. Bus Psychology, 24, 341-350.

Byrns, E.(1994). A model for a firm's optimal environmental policy. The Engineering Economist, 39 (3), 249.

Campbell, A. (1992). A Sense of Mission: Defining Direction for the Large Corporation, Reading: MA: Addison-Wesley Publishing Company.

Campbell, A. (2007). Why Would Corporations Behave in Socially Responsible Ways? An Institutional Theory of Corporate Social Responsibility. The Academy of Management Review, 32 (3), 946-967.

Carayol, N., \& Roux, P. (2009). Knowledge flows and the geography of networks: A strategic model of small world formation. Journal of Economic Behavior \& Organization, 71 (2), 414.

Cardinal L. 2001. Technological innovation in the pharmaceutical industry: the use of organizational control in managing research and development. Organization Science 12(1), 19-36.

Carnicross, F. (1992). Costing the Earth. Harvard Business School Press: Boston, MA, 1992.

Corporate Governance Indicators: http://www.developmentdata.org/governance.htm

Castells, Manuel. (1996). The Rise of the Network Society. Cambridge, MA \& Oxford, UK: Blackwell.

Casti, J., (1994). Complexification: Explaining a Paradoxical World Through the Science of Surprise. HarperCollins, New York. 
Chandler, A. D. (1998). Strategy and Structure. Cambridge, MA: MIT Press paperback edition20th printing (1st ed. 1962).

Chandler,A.D. (1962). Strategy and structure - Chapters in the History of the Industrial Enterprise, MIT Press United States ISBN 026253009.

Chang, E \& Taylor, M S (1999). Control in Multinational Corporations (MNCs): The Case of Korean Manufacturing Subsidiaries. Journal of Management, 25(4), 541-565.

Cheng, E. W. L. (2001). SEM being more effective than multiple regression in parsimonious model testing for management development research. The Journal of Management Development, 20 (7), 650-667.

Chen, D., Park, S. \& Newburry, W. (2009). Parent Contribution and Organizational Control in International Joint Ventures. Strategic Management Journal, 30(11), 11331156.

Child, J. (2005). Organization: Contemporary Principles and Practice. Cornwall: Blackwell Publishing.

Cho, K. R., \& Lee, J. (2004). Firm Characteristics and MNC's Intra-network Knowledge Sharing. Management International Review, 44 (4), 435-455.

Cho, C.H., Guidry, R., Hageman, A.M., \& Patten, D. (2012). Do actions speak louder than words? An empirical investigation of corporate environmental reputation. Accounting, Organizations and Society, 37 (1), 14-25.

Choi, C.B., \& Beamish, P.W. 2004. Split management control and international joint venture performance. Journal of International Business Studies, 35 (3), 201-215.

Christmann, P., \& Taylor, G. (2001). Globalization and the environment: Determinants of firm self-regulation in China. Journal of International Business Studies, 32 (3), 439.

Christmann, P. (2000). Effects of 'best practices' of environmental management on cost advantage: the role of complementary assets. Academy of Management Journal, 43 (4), $663-80$.

Christmann, P. (2004). Multinational companies and the natural environment: determinants of global environmental policy standardization. Academy of Management Journal, 47 (5), 747-60.

Christmann, P., \& Taylor, G. (2001). Globalization and the environment: Determinants of firm self-regulation in China. Journal of International Business Studies, 32 (3), 439-458. 
Christmann, P., \& Taylor, G. (2006). Firm self-regulation through international certifiable standards: determinants of symbolic versus substantive implementation. Journal of International Business Studies, 37 (6), 863-878.

Christos, P. (2001). Does Location Matter? An Empirical Analysis of Geographic Scope and MNC Market Valuation. Journal of International Business Studies, 32 (1), 133-155.

Clemens, B., \& Bakstran, L., (2010). A framework of theoretical lenses and strategic purposes to describe relationships among firm environmental strategy, financial performance, and environmental performance. Management Research Review, 33 (4), 393-405.

Cohen., \& Stewart, I. (1994). The Collapse of Chaos: Discovering Simplicity in a Complex world, Penguin Books, ISBN 978-0-14-029125-4.

Cormier, D., Gordon, I., \& Magnan, M. (2004). Corporate Environmental Disclosure: Contrasting Management's Perceptions with Reality. Journal of Business Ethics, 49 (2), 143-165.

Cornell, B., \& Shapiro, A. (1987). Corporate stakeholders and corporate finance. Financial Management, 16, 5-14

Cortina, J., Chen, G., \& Dunlap, W. (2001).Testing Interaction Effects in LISREL:

Examination and Illustration of Available Procedures. Organizational Research Methods, 4 (4), 324-360.

Daft, R., \& Lewin, A. (1990). Can organizational studies begin to break out of the normal science straitjacket? Organization Science, 1 (2), 1-9.

Dasgupta, S., Hettige, H., \& Wheeler, D. (2000). What improves environmental performance? Evidence from Mexican industry. Journal of Environmental Economics and Management, 3 (9), 39-66.

Dawkins, C., \& Fraas, J. W. (2011). Coming Clean: The Impact of Environmental Performance and Visibility on Corporate Climate Change Disclosure. Journal of Business Ethics, 100 (2), 303-322.

David, F.R. (2009). Strategic Management: Concepts and Cases (Twelfth Edition). Upper Saddle River, NJ: Pearson Prentice Hall.

David, F. R. (1989). How Do Companies Define Their Mission? Long Range Planning, $22(1), 90-97$.

David, S., (2001).Varieties of capitalism: the institutional foundations of comparative advantage. PA Hall - Oxford: Oxford University Press. 
Dechant, K., \& Altman, B. (1994). Environmental leadership: From compliance to competitive advantage. Academy of Management Executive, 8 (3), 7-27.

Delmas, M., \& Montiel, I. (2008). The Diffusion of Voluntary International Management Standards: Responsible Care, ISO 9000, and ISO 14001 in the Chemical Industry, Policy Studies Journal, 36 (1), 65-93.

Delmas, M., \& Toffel, M.W. (2004). Stakeholders and environmental management practices: an institutional framework .Business Strategy and the Environment, 13 (4), 209.

DiMaggio, P.J., \& Powell,W.W. (1983). The Iron Cage Revisited: Institutional Isomorphism and Collective Rationality in Organizational Fields. American Sociological Review, 48 (2), 147-160.

Donaldson, T. \& Preston, L. E. (1995). The Stakeholder Theory of the Corporation: Concepts, Evidence and Implications. Academy of Management Review, 20 (1), 65-91.

Dowell, G., Hart, S. \& Yeung, B. (2000). Do corporate environmental standards create or destroy market value? Management Science, 4 (6), 1059-1074.

Dörrenbächer, C., \& Gammelgaard, J. (2010). Multinational corporations, interorganizational networks and subsidiary charter removals. Journal of World Business, 4 (5), 206-216.

Doz, Y., \& Prahalad, C. K. (1993). Managing MNCs: A search for a new paradigm. In S. Ghosha and D. E. Westney (Eds), Organization theory and the multinational corporation: 24-50. London: Macmillan.

Dunning, J. H. (1988). The Eclectic Paradigm of International Production: A Restatement and Some Possible Extensions. Journal of International Business Studies. 19 (1), 1-31.

Dunning, J. H. (1993). Multinational Enterprises and the Global Economy. Wokinghan England: Addison-Wesley theories of MNE activity. International Business Review, 9, 163-90.

Dunning, J., \& Rugman, A., (1985). The Influence of Hymer's Dissertation on the Theory of Foreign Direct Investment. The American Economic Review, 75 (2), Papers and Proceedings of the Ninety-Seventh Annual Meeting of the American Economic Association, pp. 228-232.

Eccles, T, (1993). Implementing Strategy: two reviosionst perspectives, in Hendy J, Johnson, G. and Newton, J. (eds) Strategic Thinking: Leadership and the Management of Change, Chichester: John Wiley. 
Eden, L.,\& Lenway, S. (2001). Introductions. to the Sympoposium: The Janus Face of Globalization. Journal of International Business Studies, 32 (3), 383-400.

Elsayed, K. (2006). Reexamining the expected effect of available resources and firm size on firm environmental orientation: An empirical study of UK firms. Journal of Business Ethics, 65, 297-308.

Environmental Performance Index (EPI): (http://epi.yale.edu/Countries).

Fergus, A.H. \& Rowney, J. (2005). Sustainable Development: Lost Meaning and Opportunity? Journal of Business Ethics, 60 (1), 17-27.

Fischer, K., \& Schot, J. eds. (1993). Environmental Strategies for Industry: International Perspectives on Research Needs and Policy Implications. Washington, DC: Island Press

Fombrun, C., \& Shanley, M. (1990). What's in a name? Reputation building and corporate strategy. Academy of Management Journal, 33, 233-258.

Frances, J., Milliken, L., \& Martins, L. (1996). Searching for Common Threads: Understanding the Multiple Effects of Diversity in Organizational Groups. The Academy of Management Review, 21 (2), 402-433.

Friedman, W.G., \& Beguin, J. P. (1971). Joint International Business Ventures In Developing countries, New York, Columbia University Press.

Galbraith,G. \& Kazanjian, R. (1986). Organizing to implement strategies of diversity and globalization: the role of matrix designs. Human Resource Management, 25 (1), 3754.

Geringer, J. M., \& Hebert, L. (1989).Control And Performance of International Joint Ventures. Journal of International Business Studies, 20 (2), 235.

Ghoshal, S., Bartlett, C.A. (1990). The Multinational Corporation as an Interorganizational Network. The Academy of Management Review, 15 (4), 603-625.

Ghoshal, S. \& Bartlett, C.A. (2005). The multinational corporation as an interorganizational network, in Birkinshaw, J. and Piramal, G. (Eds), Sumantra Ghoshal on Management: A Force for Good, Prentice-Hall, London, pp. 71-104.

Ghoshal, S., Nohria, N. (1989).Internal differentiation within multinational corporations. Strategic Management Journal, 1: 323-337. 
Gilbert, D.U., \& Rasche, A. (2008). Special section accountability in a global economy: The Emergence of International Accountability Standards to Advance Corporate Social Responsibility. Journal of Business Ethics, 82(3), 755-773.

Gilbert, D.U, Rasche, A., \& Waddock, S. (2011).Accountability in a Global Economy: The Emergence of International Accountability Standards. Business Ethics Quarterly, 21 (1), 23-44.

Gladwin, T.N. (1987). Environment, development and multinational enterprises. In C.S. Pearson (Ed.), Multinational Corporations, Environment, and the Third World: 3-34, Durham, NC: Duke University Press.

Ghemawat, P. (2001). Distance still matters: the hard reality of global expansion. Harvard Business Review, 79 (8), 137-147.

Ghoshal, B. (1989). Internal differentiation within multinational corporations. Strategic Management Journal, 10 (4), 323-337.

Gomes, L., \& Ramaswamy, K. (1999). An empirical examination of the form of the relationship between multinationality and performance. Journal of International Business Studies, 30 (1), 173-188.

Granovetter, M. (1985). Economic action and social structure: The problem of embeddedness. American Journal of Sociology, 91 (3), 481-510.

Grant, R.M. (1991). The resource-based strategy theory of competitive advantage: implications for strategy formulation. California Management Review, 33(3), 114-135.

Grant, R.M. (2008). Contemporary Strategy Analysis 6th edition. Blackwell Publishing Ltd.UK.

Gray, W.B., \& Deily, M.E. (1996). Compliance and enforcement: Air pollution regulation in the U.S. steel industry. Journal of Environmental Economics and Management, 31 (1), 96.

Green Policy Score: (http://www.thedailybeast.com/newsweek/2010/10/18/greenrankings-2010-full-methodology.html).

Green Ranking Methodology 2010. (http://www.thedailybeast.com/newsweek/2010/10/18/green-rankings-2010-fullmethodology.html).

Geringer, J.M. (1986). Criteria for Selecting Partners for Joint Ventures in Industrialized Market Economies." Ph.D. diss., University of Washington. 
Grossman, G., \& Krueger, A. (1995). Economic growth and the environment. Quarterly Journal of Economics, 110 (2), 353-377.

Gruber, M., Heinemann, F., Brettel, M., \& Hungeling, S. (2010). Configurations $\quad$ of resources and capabilities and their performance implications: an exploratory study on technology ventures. Strategic Management Journal, 31 (12), 1337.

Guidry, R.P \& Patten, D.M. (2010). Newsweek's measure of corporate environmental reputation and the 'financial halo effect'. Social and Environmental Accountability Journal, 30 (1).

Gupta, A.K. \& Govindarajan, V. (2000). Knowledge flows within multinational corporations. Strategic Management Journal, 21,473-496

Hair, J. F., \& Black, W. C. (2000). Cluster analysis. In L. G. Grimm \& P. R. Yarnold (Eds.), Reading and understanding more multivariate statistics (pp. 147-205). Washington, DC: American Psychological Association

Hart, S. (1995). A Natural-Resource-Based View of the Firm. Academy of Management Review, 20 (4), 986-1014.

Harzing, A.W. (1999). Managing the Multinationals: An International Study of Control Mechanism. Cheltenham, UK: Edard Elgar.

Harzing, A.W. (2002). Acquisitions versus greenfield investments: International strategy and management of entry modes. Strategic Management Journal, 23 (3), 211.

Haverkamp, D., Bremmers, H., \& Omta, O. (2010). Stimulating environmental management performance: Towards a contingency approach. British Food Journal, 112 (11), 1237-1251.

Hedlund, G. (1986). The hypermodern MNC: A heterarchy? Human Resource Management, 2 (5), 9-36.

Hedlund, G., \& Rolander, D. (1990). Action in hierarchies : New approaches to managing the MNC. In C.A. Bartlett, Y. Doz, \& G. Hedlund (Eds.), Managing the global firm (pp. 15-46). London: Routledge.

Hill, C. \& Jones, G. (2008). Strategic Management, Houghton Mifflin Company, New York, NY.

Henriques, I., \& Sadorsky, P. (1996). The Determinants of an Environmentally Responsive Firm: An Empirical Approach. Journal of Environmental Economics and Management, 30 (3), 381-95. 
Herrmann, P. (2006). CEO Experiences.Effects on the Choice of FDI Entry Mode. Journal of Management Studies, 43 (4), 755-778.

Hoffman, A. J. (2001). Linking organizational and field - level analyses: The diffusion of corporate environmental practice. Organization \&amp; Environment, 14 (2), 133-156.

Holm, U., \& Pedersen, T. (2000). The Emergence and Impact of MNC Centres of Excellence, Macmillan Press: London.

Huang, X., (2011). Corporate control by Chinese MNCs over their foreign subsidiaries: combining institutional and resource-based perspectives. Labour \& Industry, 22 (1), 169-191.

Hunter, T., \& Bansal, P. (2007). How Standard is Standardized MNC Global Environmental Communication? Journal of Business Ethics, 71, 135-147.

Hymer, S. H. (1976). The international operations of national firms. Cambridge, MA: MIT Press.

Hymer, S. H. (1960). The International operations of national firms, a study of direct foreign investment. Massachusetts Institute of Technology, Dept. of Economics.

Hymer, S. (1970). The Efficiency (Contradictions) of Multinational Corporations. The American Economic Review, 60 (2), Papers and Proceedings of the Eighty-second Annual Meeting of the American Economic Association (May, 1970), pp. 441-448.

Isabelle, M., \& Ralston, D. A. (2002). Corporate Social Responsibility in Europe and the U.S.: Insights from Businesses' Self-Presentations. Journal of International Business Studies. 33 (3), 497-514.

Jackson, G. \& Deeg, R. (2008). Comparing capitalisms: understanding institutional diversity and its implications for international business. Journal of International Business Studies, Part Special Issue: Institutions and International Business, 39 (4), 540561.

Jaccard, J., \& Turrisi, R. (2003). Interaction Effects in Multiple Regression, Second Edition. Quantitative Applications in the Social Sciences Series Volume 72, SAGE Publications, Inc.

Jamali, D. (2010). The CSR of MNC Subsidiaries in Developing Countries: Global, Local, Substantive or Diluted? Journal of Business Ethics, 2 (93), 181-200.

Jon, I., Martinez, J., \& Carlos, J. (1991). Coordination Demands of International Strategies. Journal of International Business Studies, 22 (3), 429-444. 
Kaufmann, L., \& Roessing, S. (2005). Managing conflict of interests between headquarters and their subsidiaries regarding technology transfer to emerging markets: A framework. Journal of World Business, 40 (3), 235-253.

Kennelly, J. J., \& Lewis, E.E. (2002). Degree of internationalization and corporate environmental performance: Is there a link? International Journal of Management, 19 (3), 478-489.

King, A.A., Lenox, M.J., \& Terlaak, A. (2005). The strategic use of decentralized institutions: exploring certification with the ISO 14001 management standards. Academy of Management Journal, 48 (6), 1091-1106.

King, D. L., Case, C. J, \& Premo, K. M. (2010). Current mission statement emphasis: be ethical and go global. Academy of Strategic Management Journal, 9, 71-87.

King, A. \& Shaver, M. (2001). Are aliens green? Assessing foreign establishments' environmental conduct in the U.S. Strategic Management Journal, 22(11), 244-256.

Klassen, R.D. \& McLaughlin, C.P. (1996). The impact of environmental management on firm performance. Management Science, 42 (8), 1199-213.

Kogut, B,. \& Zander, U. (1995). Knowledge, market failure and the multinational enterprise: A reply, Journal of International Business Studies, 26 (2), 417.

Kolk, A. (2005). Environmental Reporting by Multinationals from the Triad: Convergence or Divergence. Management International Review, 45 (1), 145-166.

Kolk, A., \& Pinkse, J. (2008). A perspective on multinational enterprises and climate change: Learning from" an inconvenient truth"? Journal of International Business Studies, 39, 1359-1378.

Kolk A., \& Perego P. (2010). Determinants of the adoption of sustainability assurance statements: An international investigation. Business Strategy and the Environment, 19(3), $182-198$.

Konar, S., \& Cohen, M.A. (2001). Does the market value environmental performance? Review of Economics and Statistics, 83 (2), 281-289.

Kostova, T. (1998). Success of the transnational transfer of organizational practices within multinational companies. Research Paper Series No. 98-4, Carnegie Bosch Institute, Carnegie Mellon University.

Kostova, T. (1999). Transnational transfer of strategic organizational practices: A contextual perspective. Academy of Management Review, 24 (2), 308-324. 
Kostova, T., \& Roth, K., (2002). Adoption of an organizational practice by subsidiaries of multinational corporations: Institutional and relational effects. Academy of Management Journal, 45 (1), 215-233.

Kostova, T., \& Zaheer, S. (1999). Organizational Legitimacy under Conditions of Complexity: The case of the Multinational Enterprise. Academy of Management Review, $24(1), 64-81$.

KPMG 2008 Sustainability Report Study, Business and the Environment 19. 12 (Dec 2008): 6-7.

Krippendorff, K. H. (2003). Content Analysis: An Introduction to Its Methodology Second edition. Sage Publications: California.

Kwok, C., \& Tadesse, S. (2006). The MNC as an agent of change for host-country institutions: FDI and corruption. Journal of International Business Studies, 37 (6), $767-$ 785.

Laine, M. (2005). Meanings of the Term "Sustainable Development" in Finnish Corporate Disclosures, Accounting Forum, 29, 395-413.

Lenn, G., \& Kannan, R. (1999). An Empirical Examination of the Form of the Relationship between Multinational and Performance. Journal of International Business Studies, 30 (1), 173-187.

Levinson, A., \& Taylor, M.S. (2008). Unmasking the Pollution Haven Effect. International Economic Review, 4(9), 223-254.

Levinthal, D. (1997). Adaptation on Rugged Landscapes. Management Science, 43, 934950.

Levy, D. L. (2000). Applications and Limitations of Complexity Theory in Organization Theory and Strategy", in Jack Rabin, Gerald J. Miller, and W. Bartley Hildreth (editors), Handbook of Strategic Management, Second Edition, Marcel Dekker, New York.

Lewin, A. Y., Massini, S., \& Peeters, C. (2009). Why are companies offshoring innovation? The emerging global race for talent. Journal of International Business Studies, 40 (6), 901-925.

Lippman S.,\& Rumelt R. (1982). Uncertain imitability: an analysis of interfirm differences in efficiency under competition. Bell Journal of Economics, 13, 418-438.

Livesey, S.M. \& Kearins, K. (2002). Transparent and caring corporations? A study of sustainability reports by The Body Shop and Royal Dutch/Shell, Organization \& Environment, 15 (3), 233-58. 
Love, E., \& Kraatz, M. 2009. Character, Conformity, or the bottom line? How and why downsizing affected corporate reputation. Academy of Management Journal, 52 (2), 314

Maak, T. (2008). Undivided Corporate Responsibility: Towards a Theory of Corporate Integrity. Journal of Business Ethics, 82 (2), 353-368.

McMillan, E. (2004). Complexity, Organizations and Change. Routledge

Markides, C., \& Williamson, P.J. (1996). Corporate diversification and organizational structure: A resource based view. Academy of Management Journal, 39 (2), 340.

Markides, C. C., (1995). Diversification, restructuring and economic performance. Strategic Management Journal, 16 (2), 101-118.

Martinez, J. I. \& Jarillo, J. C. (1991). Co-ordination Demands of International Strategies. Journal of International Business Studies, 22 (3), 429-444.

Maureen, L., Cropper, W., \& Qates, E. (1992). Environmental Economics: A Survey. Journal of Economic Literature, 30 (2), 675-740.

Mauri, A. (2009). Influence of MNC Network Configuration Patterns on the Volatility of Firm Performance: An Empirical Investigation. Management International Review, 49 (6), 691-707.

McGinn, D. (2009).The greenest big companies in America. Newsweek, 28 (September), 34-54.

McMillan, E. (2004). Complexity, Organizations and Change. Routledge.London.

McWilliams, A., Siegel, D.,\& Wright, P.(2006). Introduction by guest editors corporate social responsibility: international perspectives. Journal of Business Strategies, 23 (1), 17.

Menguc, B., Auh, S., \& Ozanne, L. (2010). The Interactive Effect of Internal and External Factors on a Proactive Environmental Strategy and its Influence on a Firm's Performance. Journal of Business Ethics, 94 (2), 279-298.

Meyer, J.W., \& Rowan, B. (1977). Institutionalized Organizations: Formal Structure as Myth and Ceremony. The American Journal of Sociology, 83 (2), 340-363.

Mezias, J. M. (2002). Identifying liabilities of foreignness and strategies to minimize their effects: The case of labor lawsuit judgments in the United States. Strategic Management Journal, 23, 229-244.

Miller, D. (1987) The Structural and Environmental Correlates of Business Strategy. Strategic Management Journal, 8 (1), 55-76. 
Miller, D. (1981). Toward a new contingency perspective: the search for organizational gestalts. Journal of Management Studies, 1 (8), 1-26.

Miller S., \& Eden, L. (2006). Local density and foreign subsidiary performance. The Academy of Management Journal, 49, (2), 341-355.

Mintzberg, H., \& Waters, J.A. (1985). Of Strategies, Deliberate and Emergent: Summary. Strategic Management Journal, 6 (3), 257.

Mischen, P.A., \& Jackson, S. K. (2008). Connecting the dots: applying complexity theory, knowledge management and social network analysis to policy implementation. Public Administration Quarterly, 32 (3), 314-338.

Mitchell, Colin (2002). Selling the brand inside. Harvard Business Review, 5-1 1.

Mitchell, L. D. \& Ramey, W. D. (2011). Look How Green I Am! An Individual-Level Explanation for Greenwashing. The Journal of Applied Business and Economics, 12 (6): 40-45.

Mitchell, R. K., Agle, B. R., \& Wood, D.J. (1997).Toward a Theory of Stakeholder Identification and Salience: Defining the Principle of Who and What Really Counts, Academy of Management Review, 22(4), 853-886.

Mohan, A. (2006). Global Corporate Social Responsibilities Management in MNCS. Journal of Business Strategies, 23 (1), 9-32.

Molina-Azorín, J. F., Claver-Cortés, E., López-Gamero, M., Tarí, J. (2009). Green management and financial performance: a literature review, Management Decision, 47 (7). $1080-1100$

Moon, C., \& Lado, A. (2000). MNC-Host Government Bargaining Power Relationship: A Critique and Extension Within the Resource-Based View. Journal of Management, 2(6), 85 .

Moon, S. (2008). Corporate Environmental Behaviors in Voluntary Programs: Does Timing Matter? Social Science Quarterly, suppl. Special Issue on the Environment, 89 (5), 1102-1120.

Morhardt, J. E. (2010). Corporate social responsibility and sustainability reporting on the Internet. Business Strategy and the Environment, 19 (7), 436.

Mueller, M., Gomes dos Santos, V., \& Seuring, S. (2009). The contribution of environmental and social standards towards ensuring legitimacy in supply chain governance. Journal of Business Ethics, 89(4), 509-523. 
Myers, S. \& Majluf, N. (1984).Corporate Financing and Investment Decisions when Firms Have Information Investors Do Not Have. Journal of Financial Economics, 13, $198-221$.

Nakao, Y., Amano, A., Matsumura, K., Geba, K., \& Nakano. M. (2007). Relationship between environmental performance and financial performance: an empirical analysis of Japanese corporations. Business Strategy and the Eenvironment, 16 (2), 106.

Nelson, R., \& Winter, S. (1982). An Evolutionary Theory of Economic Change. Cambridge, MA: Harvard University Press.

Netherwood, A. (1996) 'Environmental Management Systems', in R. Welford (ed.), Corporate Environmental Management: Systems and Strategies (London: Earthscan Publications): 35-57.

Netter, J., Wasserman, W., \& Kutner, M. (1996). Applied Linear Statistical Models Fourth Edition. Homewood, IL, Irwin.

Newburry, W. (2010). Reputation and Supportive Behavior: Moderating Impacts of Foreignness, Industry and Local Exposure. Corporate Reputation Review, 12 (4), 388405.

Newburry, W. \& Zeira S. (1997). Generic differences between equity international joint ventures (EIJVs), international acquisitions (IAs) and international greenfield investments (IGIs) Implications for parent companies. Journal of World Business, 32 (2), 87-102.

Newburry, W. \& Zeira, Y. (1999). Autonomy and Effectiveness of Equity International Joint Ventures: A Comparative Analysis of Hungary and Britain. Journal of Management Studies, 36 (2), $263-285$.

Newburry, W., Zeira, Y., \& Yeheskel, O. (2003). Autonomy and effectiveness of equity international joint ventures (IJVs) in China. International Business Review, 12 (4), 395419.

Newton, T., \& Harte, G. (1997). Green business: technicist kitsch? Journal of Management Studies, 34(1) 75-98.

O'Donnell, S. (2000). Managing Foreign Subsidiaries: Agents of Headquarters, or an Interdependent Network? Strategic Management Journal, 21(5), 525-548.

Onkila, T.J. (2009). Corporate Argumentation for Acceptability: Reflections of Environmental Values and Stakeholder Relations in Corporate Environmental Statements. Journal of Business Ethics, 87 (2), 285-298. 
Panda, A., \& Gupta, R.K. (2003). Why mission statements become a show piece? Case of an Indo-American joint venture. Vikalpa, 28 (2), 23-47.

Pantzalis, C., (2001). Does location matter? An empirical analysis of geographic scope and MNC market valuation. Journal of International Business Studies. 32 (1), 133-155.

Pantzalis, C., B.J. Simkins, \& Laux, P. (2001). Operational Hedges and the Foreign Exchange Exposure of US Multinational Corporations. Journal of International Business Studies, 32, 793-812.

Pascale, R. T. (1999). Surfing the edge of chaos. Sloan Management Review, spring, 8394.

Payne, D., \& Raiborn, C.A. (2001). Sustainable development: The ethics support the economics. Journal of Business Ethics, 32(2), 157.

Peng, M.W. (2001) The resource-based view and international business. Journal of Management, 27 (6), 803-829.

Penrose, E. (1956). The Theory of the Growth of the Firm. Oxford: Oxford University Press.

Pitts, R.A. (1977). Strategies and structures for diversification. Academy of Management Journal, 2(0), 197-208.

Porter, M. (1990). The Competitive Advantage of Nations. New York, NY: The Free Press

Porter, M. 1985. Competitive Advantage. New York: Free Press.

Potoski, M. \& Prakash, A. (2005). Green clubs and voluntary governance: ISO 14001 and firms' regulatory compliance. American Journal of Political Science, 49 (2), 235-248.

Prahalad, C.K., \& Doz, Y. L. (1987). The Multinational Mission, Balancing Global Integration with local Responsiveness. New York: Free Press; London: Collier Macmillan.

Prahalad, C.K., \& Hamel, G. (1990). The Core Competence of the Corporation. Harvard Business Review, 79-91.

Prakash, A. (2000). Greening the Firm: the Politics of Corporate Environmentalism. Cambridge University Press: Cambridge. 
Raab, J., \& Kenis, P. N. (2009) . Heading toward a society of networks: Empirical developments and theoretical challenges. Journal of Management Inquiry, 18(3), 198210.

Ramaswamy, K. (1992). Multinationality and performance: A synthesis and redirection. Advances in International Comparative Management, (7), 241-267.

Rappaport, A., Flaherty, M.F. (1992). Corporate responses to environmental challenges: Initiatives by multinational management. New York: Quorum Books.

Reid, E. M. \& Toffel, M. W. (2009) . Responding to Public and Private Politics: Corporate Disclosure of Climate Change Strategies. Strategic Management Journal. 30, 1157-1178.

Rivera, J. P. de Leon. (2004). Is Greener Whiter? Voluntary Environmental Performance of Western Ski Areas. Policy Studies Journal, 32 (3), 417-37.

Rodriguez, P., Siegel, D.S., Hillman, A., \& Eden, L. (2006). Three lenses on the multinational enterprise: politics, corruption, and corporate social responsibility. Journal of International Business Studies, 37 (6), 733-46.

Rogers, E. M. (2003). Diffusion of Innovations ,Fifth Edition., New York: Free Press.

Roth, K. \& Morrison, A.J. (1990). Implementing global strategy: Characteristics of global subsidiary mandates. Journal of International Business Studies, 21 (4), 541.

Roth, K., \& Morrison, A.J. (1992). Implementing global strategy: Characteristics of global subsidiary mandates. Journal of International Business Studies 23 (4), 715.

Rugman, A.M., \& Hodgetts, R. (2001). The End of Global Strategy. European Management Journal.

Rugman, A., \& Verbeke, A. (1998). Multinational Enterprises and Public Policy. Journal of International Business Studies, 29 (1), 115-136.

Rugman, A., \& Verbeke, A. (2001). Environmental Policy and International Business. Oxford Handbook of International Business, 22, 537-558.

Russo, M.V., \& Fouts, P.A. (1997). A resource-based perspective on corporate environmental performance and profitability. Academy of Management Journal, 40 (3), 534.

Saha, M. \& Darnton, S. (2005). Green Companies or Green Con-Panies: Are Companies Really Green, or Are They Pretending to Be? Business and Society Review, 110 (2), 117157. 
Saunders, J.A. (1993). Cluster Analysis for Market Segmentation, European Journal of Marketing, 14 (7), 422-435.

Sattari, S., Pitt, L.F., \& Caruana, A. (2011). How readable are mission statements? An exploratory study . Corporate Communications. 16 (4), 282-292.

Schendler, A., \& Toffel, M. (2011). The Factor Environmental Ratings Miss . MIT Sloan Management Review, 53 (1), 17-18.

Schotter, A., \& Beamish, P.W. (2011). Performance Effects of MNC HeadquartersSubsidiary Conflict and the Role of Boundary Spanners: The Case of Headquarter Initiative Rejection, Journal of International Management, 17 (3), 243-259.

Scott, W. R. (1992). Organizations: Rational, Natural and Open Systems. Prentice-Hall, Englewood Cliffs, NJ.

Shrivastava, P. (1995). Ecocentric Management for a Risk Society. Academy of Management Review, 20, 118-137.

Sinclair P \& Walton J. (2003). Environmental reporting within the forest and paper industry. Business Strategy and the Environment, 12: 326-337.

Sinding, K. (2000). Environmental management beyond the boundaries of the firm: definitions and constraints . Business Strategy and the Environment, 9(2), 79-91

Smart, B. (Ed.). (1992). Beyond Compliance: A New Industry View of the Environment. Washington, DC: World Resources Institute.

Soleimani, A. (2011). Essays on Corporate Reputation: Antecedents and Consequences. Unpublished Doctoral Dissertation. Florida International University.

Sorsa, V. (2008). How to explain socially responsible corporate actions institutionally: theoretical and methodological critique. Electronic Journal of Business Ethics and Organizational Studies, 13(1), 32-41.

Starik, M. (1995). Should trees have managerial standing? Toward stakeholder status for nonhuman nature. Journal of Business Ethics, 1(4), 207-217.

Stopford, J. M.\& Wells, L. (1972). Managing the Multinational Enterprise. Organization of the Firm and Ownership of the Subsidiaries, New York: Basic Books.

Suchman, M. (1995). Managing legitimacy: Strategic and institutional approaches. Academy of Management Review 20: 571-610. 
Szulanski, G. (1996). Exploring Internal Stickiness: Impediments to the Transfer of Best Practice within the Firm. Strategic Management Journal, 17, 27-43.

Tallman, S., \& Li, J.T. (1996). The effects of international diversity and product diversity on the performance of multinational firms. Academy of Management Journal, 39(1), 179-196.

Teece, D.J. (1986). Transaction cost economics and the multinational enterprise an assessment. Journal of Economic Behavior and Organization, 7 (1), 21-45.

Teece, D. J., Pisano, G., \& Shuen, A. (1997). Dynamic capabilities and strategic management. Strategic Management Journal, (18) 7, 509-533.

Thacker, J. W., Fields, M. W., \& Tetrick, L. E. (1989). The factor structure of union commitment: An application of confirmatory factor analysis. Journal of Applied Psychology, (74), 228- 232.

Trucost (2010) What We Do. http://www.trucost.com/ what-we-do. retrieved April 2012

Tsai, T., \& Child, J. (1997). Strategic responses of multinational corporations to environmental demands. Journal of General Management, 23(1), 1-22.

Tsai, W., (2000). Social capital, strategic relatedness and the formation of intraorganization. Strategic Management Journal, 21 (9), 925.

Tsai, W. (2001). Knowledge Transfer in Intraorganizational Networks: Effects of Network Position and Absorptive Capacity on Business Unit Innovation and Performance. The Academy of Management Journal, 44 (5), 996-1004.

Van den T. W. M. Brink \& Van der Woerd, F. (2004). Industry Specific Sustainability Benchmarks: An ECSF Pilot Bridging Corporate Sustainability with Social Responsible Investments. Journal of Business Ethics, 55 (2), 187-203.

Varadarajan, Rajan \& Vasudevan, R. (1987). Diversification and Performance: A Reexamination Using a New Two-Dimensional Conceptualization of Diversity in Firms, Academy of Management Journal, 30 (2), 380-393.

Waddock, S. (2000). The multiple bottom lines of corporate citizenship: Social investing, reputation, and responsibility audits. Business and Society Review, 105, 323-345.

Waddock, S. (2003). Myths and Realities of Social Investing', Organization and Environment 16 (3), 369-380.

Waddock, S.A., \& Graves, S.B. (1997). The corporate social performance-financial performance Link. Strategic Management Journal, 18, 303-319. 
Waldman, D.A., Siegel, D.S., \& Javidan, M. (2006). Components of CEO Transformational Leadership and Corporate Social Responsibility. Journal of Management Studies, 43 (8), 1703-1725.

Westphal, J.D. \& Zajac, E.J. (1994). Substance and symbolism in CEOs' long-term incentive plans. Administrative Science Quarterly, 39 (3), 367-390.

Winer, B, J, Brown, D., \& Michels, K. M. (1991). Statistical Principles in Experimental Design. Mcgraw-Hills Series in Psychology.

Wolf, J., \& Egelhoff, W. (2002). A reexamination and extension of international strategystructure theory. Strategic Management Journal, 23 (2), 181.

World Competiveness Report: http://www.weforum.org/issues/global-competitiveness

Zaheer, S. (1995). Overcoming the liabilities of foreignness. Academy of Management Journal, 38 (2), 341-363.

Zyglidopoulos, S. C. (2002). The social and environmental responsibilities of multinationals: Evidence from the Brent Spar case. Journal of Business Ethics, 36 (1), $141-151$. 
APPENDICES 
Appendix 1 - List of Companies in Sample 
Appendix 1: List of Companies in Sample

\begin{tabular}{|c|c|c|}
\hline Ticker & Company & SIC Code \\
\hline $\mathrm{A}$ & AGILENT TECHNOLOGIES INC & 3825 \\
\hline AA & ALCOA INC & 3350 \\
\hline AAPL & APPLE INC & 3571 \\
\hline $\mathrm{ABT}$ & ABBOTT LABORATORIES & 2834 \\
\hline $\mathrm{ADM}$ & ARCHER-DANIELS-MIDLAND CO & 2070 \\
\hline $\mathrm{AGCO}$ & AGCO CORP & 3523 \\
\hline AGN & ALLERGAN INC & 2834 \\
\hline AMAT & APPLIED MATERIALS INC & 3559 \\
\hline AMD & ADVANCED MICRO DEVICES & 3674 \\
\hline APH & AMPHENOL CORP & 3678 \\
\hline AVP & AVON PRODUCTS & 2844 \\
\hline AVY & AVERY DENNISON CORP & 2670 \\
\hline $\mathrm{BA}$ & BOEING CO & 3721 \\
\hline BAX & BAXTER INTERNATIONAL INC & 2836 \\
\hline BDX & BECTON DICKINSON \& CO & 3841 \\
\hline $\mathrm{BEC}$ & BECKMAN COULTER INC & 3826 \\
\hline BHI & BAKER HUGHES INC & 3533 \\
\hline BIIB & BIOGEN IDEC INC & 2836 \\
\hline BLL & BALL CORP & 3411 \\
\hline BMS & BEMIS CO INC & 2670 \\
\hline BMY & BRISTOL-MYERS SQUIBB CO & 2834 \\
\hline BSX & BOSTON SCIENTIFIC CORP & 3841 \\
\hline BWA & BORGWARNER INC & 3714 \\
\hline $\mathrm{CAG}$ & CONAGRA FOODS INC & 2000 \\
\hline CAT & CATERPILLAR INC & 3531 \\
\hline $\mathrm{CBE}$ & COOPER INDUSTRIES PLC & 3640 \\
\hline $\mathrm{CCE}$ & COCA-COLA ENTERPRISES INC & 2086 \\
\hline CCK & CROWN HOLDINGS INC & 3411 \\
\hline $\mathrm{CL}$ & COLGATE-PALMOLIVE CO & 2844 \\
\hline CLX & CLOROX CO/DE & 2842 \\
\hline CMI & CUMMINS INC & 3510 \\
\hline $\mathrm{COP}$ & CONOCOPHILLIPS & 2911 \\
\hline $\mathrm{CPB}$ & CAMPBELL SOUP CO & 2030 \\
\hline $\mathrm{CSCO}$ & CISCO SYSTEMS INC & 3576 \\
\hline CVX & CHEVRON CORP & 2911 \\
\hline DAN & DANA HOLDING CORP & 3714 \\
\hline
\end{tabular}




\begin{tabular}{|c|c|c|}
\hline $\mathrm{DE}$ & DEERE \& CO & 3523 \\
\hline DELL & DELL INC & 3571 \\
\hline DF & DEAN FOODS CO & 2020 \\
\hline DHR & DANAHER CORP & 3823 \\
\hline DOV & DOVER CORP & 3559 \\
\hline DOW & DOW CHEMICAL & 2821 \\
\hline ECL & ECOLAB INC & 2842 \\
\hline EK & EASTMAN KODAK CO & 3861 \\
\hline EL & LAUDER (ESTEE) COS INC -CL A & 2844 \\
\hline EMC & EMC CORP/MA & 3572 \\
\hline EMN & EASTMAN CHEMICAL CO & 2821 \\
\hline EMR & EMERSON ELECTRIC CO & 3600 \\
\hline ETN & EATON CORP & 3620 \\
\hline $\mathrm{F}$ & FORD MOTOR CO & 3711 \\
\hline FO & FORTUNE BRANDS INC & 3490 \\
\hline FTI & FMC TECHNOLOGIES INC & 3533 \\
\hline GD & GENERAL DYNAMICS CORP & 3790 \\
\hline GIS & GENERAL MILLS INC & 2040 \\
\hline GLW & CORNING INC & 3679 \\
\hline GR & GOODRICH CORP & 3728 \\
\hline GRMN & GARMIN LTD & 3812 \\
\hline GSK & GLAXOSMITHKLINE PLC & 2834 \\
\hline GT & GOODYEAR TIRE \& RUBBER CO & 3011 \\
\hline HAS & HASBRO INC & 3944 \\
\hline HBI & HANESBRANDS INC & 2250 \\
\hline HES & HESS CORP & 2911 \\
\hline HNZ & HEINZ (H J) CO & 2030 \\
\hline HOG & HARLEY-DAVIDSON INC & 3751 \\
\hline $\mathrm{HON}$ & HONEYWELL INTERNATIONAL INC & 3728 \\
\hline HPQ & HEWLETT-PACKARD CO & 3570 \\
\hline HRL & HORMEL FOODS CORP & 2011 \\
\hline HRS & HARRIS CORP & 3663 \\
\hline HSY & HERSHEY CO & 2060 \\
\hline HUN & HUNTSMAN CORP & 2860 \\
\hline INTC & INTEL CORP & 3674 \\
\hline IP & INTL PAPER CO & 2631 \\
\hline ITT & ITT CORP & 3812 \\
\hline ITW & ILLINOIS TOOL WORKS & 3540 \\
\hline JAH & JARDEN CORP & 3089 \\
\hline JBL & JABIL CIRCUIT INC & 3672 \\
\hline
\end{tabular}




\begin{tabular}{|c|c|c|}
\hline JCI & JOHNSON CONTROLS INC & 2531 \\
\hline JNJ & JOHNSON \& JOHNSON & 2834 \\
\hline JNPR & JUNIPER NETWORKS INC & 3576 \\
\hline $\mathrm{K}$ & KELLOGG CO & 2040 \\
\hline KFT & KRAFT FOODS INC & 2000 \\
\hline KMB & KIMBERLY-CLARK CORP & 2621 \\
\hline $\mathrm{KO}$ & COCA-COLA CO & 2080 \\
\hline LEA & LEAR CORP & 2531 \\
\hline LEG & LEGGETT \& PLATT INC & 2510 \\
\hline LIFE & LIFE TECHNOLOGIES CORP & 2836 \\
\hline LLY & LILLY (ELI) \& CO & 2834 \\
\hline LMT & LOCKHEED MARTIN CORP & 3760 \\
\hline MAS & MASCO CORP & 3430 \\
\hline MAT & MATTEL INC & 3942 \\
\hline MDT & MEDTRONIC INC & 3845 \\
\hline MMM & $3 \mathrm{M} \mathrm{CO}$ & 2670 \\
\hline MO & ALTRIA GROUP INC & 2111 \\
\hline MRK & MERCK \& CO & 2834 \\
\hline MRO & MARATHON OIL CORP & 2911 \\
\hline MSI & MOTOROLA SOLUTIONS INC & 3663 \\
\hline MU & MICRON TECHNOLOGY INC & 3674 \\
\hline MWV & MEADWESTVACO CORP & 2631 \\
\hline NCR & NCR CORP & 3578 \\
\hline NKE & NIKE INC & 3021 \\
\hline $\mathrm{NOC}$ & NORTHROP GRUMMAN CORP & 3812 \\
\hline NOV & NATIONAL OILWELL VARCO INC & 3533 \\
\hline NUE & NUCOR CORP & 3312 \\
\hline NWL & NEWELL RUBBERMAID INC & 3842 \\
\hline $\mathrm{OC}$ & OWENS CORNING & 3290 \\
\hline OI & OWENS-ILLINOIS INC & 3221 \\
\hline OSK & OSHKOSH CORP & 3711 \\
\hline PBI & PITNEY BOWES INC & 3579 \\
\hline PCAR & PACCAR INC & 3711 \\
\hline PEP & PEPSICO INC & 2080 \\
\hline PFE & PFIZER INC & 2834 \\
\hline PG & PROCTER \& GAMBLE CO & 2840 \\
\hline $\mathrm{PH}$ & PARKER-HANNIFIN CORP & 3490 \\
\hline PPG & PPG INDUSTRIES INC & 2851 \\
\hline $\mathrm{PX}$ & PRAXAIR INC & 2810 \\
\hline QCOM & QUALCOMM INC & 3663 \\
\hline
\end{tabular}




\begin{tabular}{|c|l|c|}
\hline RAI & REYNOLDS AMERICAN INC & 2111 \\
\hline ROK & ROCKWELL AUTOMATION & 3620 \\
\hline RRD & DONNELLEY (R R) \& SONS CO & 2750 \\
\hline RTN & RAYTHEON CO & 3812 \\
\hline SEE & SEALED AIR CORP & 2670 \\
\hline SFD & SMITHFIELD FOODS INC & 2011 \\
\hline SHW & SHERWIN-WILLIAMS CO & 2851 \\
\hline SLE & SARA LEE CORP & 2000 \\
\hline SPW & SPX CORP & 3612 \\
\hline SUN & SUNOCO INC & 2911 \\
\hline SYK & STRYKER CORP & 3842 \\
\hline TAP & MOLSON COORS BREWING CO & 2082 \\
\hline TEX & TEREX CORP & 3531 \\
\hline TKR & TIMKEN CO & 3562 \\
\hline TMO & THERMO FISHER SCIENTIFIC INC & 3826 \\
\hline TRW & TRW AUTOMOTIVE HOLDINGS CORP & 3714 \\
\hline TSN & TYSON FOODS INC -CL A & 2011 \\
\hline TSO & TESORO CORP & 2911 \\
\hline TXN & TEXAS INSTRUMENTS INC & 3674 \\
\hline TXT & TEXTRON INC & 3721 \\
\hline UTX & UNITED TECHNOLOGIES CORP & 3720 \\
\hline VFC & VF CORP & 2300 \\
\hline VLO & VALERO ENERGY CORP & 2911 \\
\hline WDC & WESTERN DIGITAL CORP & 3672 \\
\hline WHR & WHIRLPOOL CORP & 2900 \\
\hline WY & WEYERHAEUSER CO & 3577 \\
\hline XOM & EXXON MOBIL CORP & \\
\hline XRX & XEROX CORP & \\
\hline & & 3611 \\
\hline
\end{tabular}


Appendix 2 - MNCs Mission Statement Summary 
Appendix 2: MNCs Mission Statement Summary

\begin{tabular}{|c|c|c|c|c|}
\hline $\begin{array}{l}\text { Ticker } \\
\text { Symbol }\end{array}$ & $\begin{array}{l}\text { Company } \\
\text { Name }\end{array}$ & Mission Statement & Vision Statement & $\begin{array}{c}\text { Code } 1= \\
\text { yes } \\
\text { Code } 0= \\
\text { No }\end{array}$ \\
\hline A & $\begin{array}{c}\text { AGILENT } \\
\text { TECHNOLOGIE } \\
\text { S INC }\end{array}$ & $\begin{array}{l}\text { Agilent Technologies is dedicated to innovation and } \\
\text { contribution, trust, respect, teamwork, and } \\
\text { uncompromising integrity. We also thrive on speed, } \\
\text { focus, and accountability. Everyday, at all levels, we } \\
\text { strive to create an environment where each individual is } \\
\text { included and valued. " }\end{array}$ & $\begin{array}{l}\text { We are a company of inventors, explorers, } \\
\text { gineers, and visionaries!" }\end{array}$ & 0 \\
\hline AA & ALCOA INC & & $\begin{array}{l}\text { Alcoa, our vision is to be the best company } \\
\text { in the world - in the eyes of our } \\
\text { customers, shareholders, communities } \\
\text { and people. We expect and demand the } \\
\text { best we have to offer by always keeping } \\
\text { Alcoa's values top of mind" }\end{array}$ & 0 \\
\hline AAPL & APPLE INC & $\begin{array}{l}\text { Apple is committed to ensuring the highest standards of } \\
\text { social responsibility in everything we do. The } \\
\text { companies we do business with must provide safe } \\
\text { working conditions, treat employees fairly, and use } \\
\text { environmentally responsible manufacturing processes } \\
\text { wherever Apple products are made. " }\end{array}$ & & 1 \\
\hline $\mathrm{ABT}$ & $\begin{array}{c}\text { ABBOTT } \\
\text { LABORATORIE } \\
\mathrm{S}\end{array}$ & $\begin{array}{l}\text { To improve lives by providing cost-effective health care } \\
\text { products and services }\end{array}$ & $\begin{array}{c}\text { Abbott's vision is to be the world's premier } \\
\text { health care company. Simply put, we } \\
\text { want to be the best - the best employer, } \\
\text { the best health care supplier, the best } \\
\text { business partner, the best investment and } \\
\text { the best neighbor." }\end{array}$ & 0 \\
\hline ADM & $\begin{array}{c}\text { ARCHER- } \\
\text { DANIELS- } \\
\text { MIDLAND CO }\end{array}$ & $\begin{array}{l}\text { To Unlock the Potential of Nature to Improve the } \\
\text { Quality of Life }\end{array}$ & & 1 \\
\hline AGCO & AGCO CORP & \multicolumn{2}{|c|}{ Profitable growth through superior customer service, innovation, quality and commitment } & 0 \\
\hline
\end{tabular}




\begin{tabular}{|c|c|c|c|c|}
\hline $\mathrm{AGN}$ & ALLERGAN INC & $\begin{array}{c}\text { The Allergan Foundation is committed to providing a lasting and positive } \\
\text { impact in the community. } \\
\text { To that end, The Allergan Foundation focuses its support in four } \\
\text { philanthropic areas: the arts, civic } \\
\text { programs, education, and health and human services. As part of The } \\
\text { Allergan Foundation's commitment } \\
\text { to health and human services, it also supports selected initiatives, known as } \\
\text { "Focus Grants," to improve } \\
\text { patient diagnosis, treatment, care and quality of life, or to otherwise } \\
\text { promote access to quality health care. }\end{array}$ & & 0 \\
\hline AMAT & $\begin{array}{l}\text { APPLIED } \\
\text { MATERIALS } \\
\text { INC }\end{array}$ & $\begin{array}{l}\text { Applied Materials' mission is to be the leading supplier of semiconductor } \\
\text { fabrication solutions worldwide-through innovation and enhancement of } \\
\text { customer productivity with systems and service solutions." }\end{array}$ & & 0 \\
\hline AMD & $\begin{array}{l}\text { ADVANCED } \\
\text { MICRO } \\
\text { DEVICES }\end{array}$ & $\begin{array}{c}\text { Because our customers' needs are ever-changing, AMD understands the value } \\
\text { of looking towards-and keeping pace with-the future. To help ensure } \\
\text { we meet our customers' needs today and tomorrow, AMD invests in state- } \\
\text { of-the-art technology research many years in advance of first commercial } \\
\text { use." }\end{array}$ & $\begin{array}{l}\text { ike other world-class } \\
\text { companies, we are } \\
\text { proud of our } \\
\text { success, but we } \\
\text { are never } \\
\text { satisfied. At } \\
\text { AMD, we are } \\
\text { committed to } \\
\text { delivering the } \\
\text { innovative } \\
\text { solutions our } \\
\text { customers need, } \\
\text { building the } \\
\text { framework for } \\
\text { sustainable } \\
\text { growth going } \\
\text { forward. }\end{array}$ & 0 \\
\hline AMGN & AMGEN INC & $\begin{array}{c}\text { Amgen strives to serve patients by transforming the promise of science and } \\
\text { biotechnology into therapies that have the power to restore health or even } \\
\text { save lives. In everything we do, we aim to fulfill our mission to serve } \\
\text { patients. And every step of the way, we are guided by the values that } \\
\text { define us. " }\end{array}$ & & \\
\hline
\end{tabular}




\begin{tabular}{|c|c|c|c|c|}
\hline APH & $\begin{array}{l}\text { AMPHENOL } \\
\text { CORP }\end{array}$ & $\begin{array}{c}\text { Amphenol Backplane System's mission is to be the recognized } \\
\text { worldwide leader in backplane systems to the military and } \\
\text { aerospace market; delivering on time and defect free. } \\
\text { We will accomplish this mission by: } \\
\text { • Providing the highest quality customer service. } \\
\text { - Developing industry leading products } \\
\text { and services. } \\
\text { - Focusing on cost effective, } \\
\text { innovative systems solutions. } \\
\text { - Continuous improvement } \\
\text { of processes. }\end{array}$ & $\begin{array}{c}\text { Earning our customer's } \\
\text { respect and } \\
\text { loyalty by } \\
\text { providing high } \\
\text { quality products, } \\
\text { services, and } \\
\text { solutions that } \\
\text { meet or exceed all } \\
\text { expectations. } \\
\text { • Achieving our } \\
\text { corporate } \\
\text { objectives and } \\
\text { maintaining the } \\
\text { necessary } \\
\text { resources to attain } \\
\text { financial stability, } \\
\text { flexibility, and } \\
\text { growth. } \\
\text { •Empowering and } \\
\text { recognizing } \\
\text { employees by } \\
\text { providing } \\
\text { opportunities, } \\
\text { based on } \\
\text { performance, in a } \\
\text { safe, exciting, and } \\
\text { inclusive } \\
\text { environment that } \\
\text { values their } \\
\text { strengths and } \\
\text { diversity. }\end{array}$ & 0 \\
\hline ATI & $\begin{array}{c}\text { ALLEGHENY } \\
\text { TECHNOLOGIE } \\
\text { S INC }\end{array}$ & $\begin{array}{c}\text { Allegheny Technologies Incorporated (ATI) is Building the World's Best } \\
\text { Specialty Metals Company®. The cornerstones of our value system are } \\
\text { based on achieving the highest ethical standards, maintaining strong } \\
\text { customer focus and providing challenging and rewarding opportunities for } \\
\text { our employees }\end{array}$ & & 1 \\
\hline
\end{tabular}




\begin{tabular}{|c|c|c|c|c|}
\hline AVP & $\begin{array}{c}\text { AVON } \\
\text { PRODUCTS }\end{array}$ & $\begin{array}{l}\text { We will build a unique portfolio of Beauty and related brands, striving to } \\
\text { surpass our competitors in quality, innovation and value, and elevating our } \\
\text { image to become the Beauty company most women turn to worldwide." }\end{array}$ & $\begin{array}{l}\text { o be the company that } \\
\text { best understands } \\
\text { and satisfies the } \\
\text { product, service } \\
\text { and self- } \\
\text { fulfillment needs } \\
\text { of women - } \\
\text { globally } \\
\end{array}$ & 0 \\
\hline AVY & $\begin{array}{l}\text { AVERY } \\
\text { DENNISON } \\
\text { CORP }\end{array}$ & & $\begin{array}{c}\text { o be recognized as the } \\
\text { world's best } \\
\text { coating and } \\
\text { converting } \\
\text { company by } \\
\text { providing } \\
\text { innovative } \\
\text { decorating, } \\
\text { information } \\
\text { transfer and } \\
\text { bonding solutions } \\
\text { that enable our } \\
\text { customers' } \\
\text { success." }\end{array}$ & 0 \\
\hline $\mathrm{BA}$ & BOEING CO & $\begin{array}{c}\text { Run healthy core businesses Leverage strengths into new products and } \\
\text { services. Open new frontiers. People working together as a global } \\
\text { enterprise for aerospace leadership }\end{array}$ & & 0 \\
\hline BAX & $\begin{array}{l}\text { BAXTER } \\
\text { INTERNATION } \\
\text { AL INC }\end{array}$ & $\begin{array}{c}\text { Baxter International Inc. develops, manufactures and markets products that } \\
\text { save and sustain the lives of people with hemophilia, immune disorders, } \\
\text { infectious diseases, kidney disease, trauma, and other chronic and acute } \\
\text { medical conditions. As a global, diversified healthcare company, Baxter } \\
\text { applies a unique combination of expertise in medical devices, } \\
\text { pharmaceuticals and biotechnology to create products that advance patient } \\
\text { care worldwide }\end{array}$ & & 0 \\
\hline
\end{tabular}




\begin{tabular}{|c|c|c|c|c|}
\hline BDX & $\begin{array}{c}\text { BECTON } \\
\text { DICKINSON \& } \\
\text { CO }\end{array}$ & & $\begin{array}{l}\text { Become the } \\
\text { organization most } \\
\text { known for } \\
\text { eliminating } \\
\text { unnecessary } \\
\text { suffering and } \\
\text { death from } \\
\text { disease, and in so } \\
\text { doing, become } \\
\text { one of the best } \\
\text { performing } \\
\text { companies in the } \\
\text { world." }\end{array}$ & 0 \\
\hline BEC & $\begin{array}{c}\text { BECKMAN } \\
\text { COULTER INC }\end{array}$ & $\begin{array}{l}\text { Beckman Coulter is ... Science Serving Humanity. We exist to advance } \\
\text { medical science. We apply the infinite promise of biotechnology to serve } \\
\text { the world's healthcare needs. Our mission is to be recognized as the world } \\
\text { leader in blood cell analysis systems. Our strategy for achieving this is: We } \\
\text { will lead in the application of emerging technologies to meet the present } \\
\text { and future needs of worldwide customers for blood cell analysis. } \\
\text { We will provide the best worldwide sales and customer support services. } \\
\text { We will foster a work environment characterized by open communications, } \\
\text { quality practices, teamwork, pride, self-development, and respect for each } \\
\text { individual. } \\
\text { We will remain private and independent }\end{array}$ & & 0 \\
\hline
\end{tabular}




\begin{tabular}{|c|c|c|c|}
\hline BG & BUNGE LTD & $\begin{array}{l}\text { Our mission is to be the best oilseed and grain based agribusiness and food } \\
\text { ingredient company in North America. } \\
\text { We will combine our strengths in commodity processing and risk } \\
\text { management with a customer-focused approach to product development } \\
\text { and marketing in order to excel in each of the businesses in which we } \\
\text { operate. } \\
\text { Our success will be based on a balanced commitment to: } \\
\text { •Continually grow and improve our businesses. } \\
\text { •Provide consistent, quality products and services to our customers. } \\
\cdot \text { Be a low-cost and efficient producer. } \\
\text {-Treat our shareholders' investments as if it were our own. } \\
\text {-Maintain a safe and rewarding workplace for our employees, with } \\
\text { opportunities for growth. } \\
\text { •Uphold high standards of fairness and honesty in dealing with our } \\
\text { stakeholders }\end{array}$ & 1 \\
\hline BHI & $\begin{array}{c}\text { BAKER } \\
\text { HUGHES INC }\end{array}$ & $\begin{array}{l}\text { The Baker Hughes Core Values and Keys to Success are the basis for } \\
\text { establishing a common culture for Baker Hughes. Our Core Values are: } \\
\text { Integrity, Teamwork, Performance, and Learning. Our Keys to Success are } \\
\text { four priorities that should guide decision-making in Baker Hughes: Engage } \\
\text { People, Deliver Value, Be Cost Efficient, Resource Effectively }\end{array}$ & 0 \\
\hline
\end{tabular}




\begin{tabular}{|c|c|c|c|}
\hline BIIB & $\begin{array}{c}\text { BIOGEN IDEC } \\
\text { INC }\end{array}$ & $\begin{array}{l}\text { Biogen Idec, we are dedicated to making a difference in the lives of the } \\
\text { patients we serve by creating new therapies for serious unmet medical } \\
\text { needs. But our commitment to improving lives doesn't stop with patients. } \\
\text { We strive to employ the same innovative spirit we use in developing new } \\
\text { therapies to serve the communities in which we live and work and to } \\
\text { protect our planet's resources by reducing our impact on the environment. } \\
\text { Patients } \\
\text { Through our work, we aim to improve the quality of countless lives. Learn } \\
\text { more about our commitment to our patients. } \\
\text { Community } \\
\text { We believe it is our responsibility to advance care and enhance the lives of } \\
\text { everyone our business touches. Learn more about how we give back to the } \\
\text { community. } \\
\text { Environment } \\
\text { minimize these impacts across all areas of our enterprise. Learn more about } \\
\text { our environmental efforts. }\end{array}$ & 1 \\
\hline BLL & BALL CORP & $\begin{array}{c}\text { To be the premier provider to beverage, food and aerospace and technologies } \\
\text { customers of the products and services that we offer as we aggressively } \\
\text { manage our business, and to explore and pursue acquisitions, divestitures, } \\
\text { strategic alliances and other changes that would benefit Ball's } \\
\text { shareholders." }\end{array}$ & 0 \\
\hline BMS & BEMIS CO INC & $\begin{array}{c}\text { Founded in 1858, Bemis' unwavering dedication to a sustainable business } \\
\text { strategy has resulted in a successful, agile organization that is and will } \\
\text { remain: } \\
\text { A business committed to demonstrating the highest level of ethics and } \\
\text { integrity possible in internal and external interactions } \\
\text { A valued supplier of quality products } \\
\text { An employer providing a challenging and satisfying work } \\
\text { experience for employees } \\
\text { A rewarding investment for shareholders } \\
\text { A responsible member of the communities in which we operate }\end{array}$ & 1 \\
\hline
\end{tabular}




\begin{tabular}{|c|c|c|c|c|}
\hline BMY & $\begin{array}{c}\text { BRISTOL- } \\
\text { MYERS SQUIBB } \\
\text { CO }\end{array}$ & $\begin{array}{c}\text { Our company's mission is to extend and enhance human life by providing the } \\
\text { highest-quality biopharmaceutical products }\end{array}$ & $\begin{array}{c}\text { We pledge -- to our } \\
\text { patients and } \\
\text { customers, to our } \\
\text { employees and } \\
\text { partners, to our } \\
\text { shareholders and } \\
\text { neighbors, and to } \\
\text { the world we } \\
\text { serve -- to act on } \\
\text { our belief that the } \\
\text { priceless } \\
\text { ingredient of } \\
\text { every product is } \\
\text { the honor and } \\
\text { integrity of its } \\
\text { maker }\end{array}$ & 0 \\
\hline BSX & $\begin{array}{l}\text { BOSTON } \\
\text { SCIENTIFIC } \\
\text { CORP }\end{array}$ & $\begin{array}{l}\text { Boston Scientific's mission is to improve the quality of patient care and the } \\
\text { productivity of health care delivery through the development and advocacy } \\
\text { of less-invasive medical devices and procedures. This is accomplished } \\
\text { through the continuing refinement of existing products and procedures and } \\
\text { the investigation and development of new technologies that can reduce } \\
\text { risk, trauma, cost, procedure time and the need for aftercare. " }\end{array}$ & & 0 \\
\hline BWA & $\begin{array}{l}\text { BORGWARNER } \\
\text { INC }\end{array}$ & & \begin{tabular}{|} 
BorgWarner is the \\
recognized leader \\
in advanced \\
products and \\
technologies that \\
satisfy customer \\
needs in \\
powertrain and \\
systems solutions"
\end{tabular} & 0 \\
\hline CAG & $\begin{array}{l}\text { CONAGRA } \\
\text { FOODS INC }\end{array}$ & & $\begin{array}{c}\text { pne company growing } \\
\text { by nourishing } \\
\text { lives and finding a } \\
\text { better way today }\end{array}$ & 0 \\
\hline
\end{tabular}




\begin{tabular}{|c|c|c|c|c|}
\hline & & & $\begin{array}{c}\text {... one bite at a } \\
\text { time." }\end{array}$ & \\
\hline CAT & $\begin{array}{l}\text { CATERPILLAR } \\
\text { INC }\end{array}$ & $\begin{array}{l}\text { Caterpillar will be the leader in providing the best value in machines, engines } \\
\text { and support services for customers dedicated to building the world's } \\
\text { infrastructure and developing and transporting its resources. We provide } \\
\text { the best value to customers. Caterpillar people will increase shareholder } \\
\text { value by aggressively pursuing growth and profit opportunities that } \\
\text { leverage our engineering, manufacturing, distribution, information } \\
\text { management and financial services expertise. We grow profitably. } \\
\text { Caterpillar will provide its worldwide workforce with an environment that } \\
\text { stimulates diversity, innovation, teamwork, continuous learning and } \\
\text { improvement and rewards individual performance. We develop and reward } \\
\text { people. Caterpillar is dedicated to improving the quality of life while } \\
\text { sustaining the quality of our earth. We encourage social responsibility." }\end{array}$ & $\begin{array}{c}\text { Be the global leader in } \\
\text { customer value }\end{array}$ & 1 \\
\hline CBE & $\begin{array}{l}\text { COOPER } \\
\text { INDUSTRIES } \\
\quad \text { PLC }\end{array}$ & $\begin{array}{c}\text { The purpose of the Cooper Tire \& Rubber Company is to earn money for its } \\
\text { shareholders and increase the value of their investment. We will do that } \\
\text { through growing the company, controlling assets and properly structuring } \\
\text { the balance sheet, thereby increasing EPS, cash flow, and return on } \\
\text { invested capital }\end{array}$ & & 0 \\
\hline $\mathrm{CCE}$ & $\begin{array}{l}\text { COCA-COLA } \\
\text { ENTERPRISES } \\
\text { INC }\end{array}$ & $\begin{array}{l}\text { Our commitment is to provide products and services that meet the beverage } \\
\text { and business needs of our customers and consumers. In doing so, we } \\
\text { provide sound and rewarding business opportunities and benefits for } \\
\text { customers, suppliers, distributors and communities. " }\end{array}$ & & 0 \\
\hline $\mathrm{CCK}$ & $\begin{array}{c}\text { CROWN } \\
\text { HOLDINGS INC }\end{array}$ & $\begin{array}{l}\text { Customer satisfaction is Crown's highest priority. We achieve this goal by } \\
\text { continuously improving the cost effectiveness and performance of all our } \\
\text { products and processes, as well as focusing on innovation." }\end{array}$ & & 0 \\
\hline CL & $\begin{array}{l}\text { COLGATE- } \\
\text { PALMOLIVE } \\
\quad \text { CO }\end{array}$ & $\begin{array}{l}\text { As a Company that strives to be the best truly global consumer products } \\
\text { company, we are committed to doing business with integrity and respect } \\
\text { for all people and for the world around us }\end{array}$ & $\begin{array}{l}\text { we plan our strategies } \\
\text { to sustain growth } \\
\text { for the years to } \\
\text { come, our core } \\
\text { values of Caring, }\end{array}$ & 1 \\
\hline
\end{tabular}




\begin{tabular}{|c|c|c|c|c|}
\hline & & & $\begin{array}{l}\text { Global Teamwork } \\
\text { and Continuous } \\
\text { Improvement will } \\
\text { continue to drive } \\
\text { our future } \\
\text { initiatives }\end{array}$ & \\
\hline CLX & CLOROX CO/DE & We make everyday life better, everyday & & 0 \\
\hline CMI & CUMMINS INC & $\begin{array}{c}\text { "Motivating people to act like owners working together. Exceeding customer } \\
\text { expectations by always being first to market with the best products. } \\
\text { Partnering with our customers to make sure that they succeed. Demanding } \\
\text { that everything we do leads to a cleaner, healthier, safer environment. } \\
\text { Creating wealth for all stakeholders." }\end{array}$ & $\begin{array}{l}\text { Making people's lives } \\
\text { better by } \\
\text { unleashing the } \\
\text { Power of } \\
\text { Cummins. }\end{array}$ & 1 \\
\hline COP & $\begin{array}{c}\text { CONOCOPHILLI } \\
\text { PS }\end{array}$ & Use our pioneering spirit to responsibly deliver energy to the world." & & 0 \\
\hline CPB & $\begin{array}{l}\text { CAMPBELL } \\
\text { SOUP CO }\end{array}$ & $\begin{array}{l}\text { Together we will build the world's most extraordinary food company by } \\
\text { nourishing people's lives everywhere, every day }\end{array}$ & & 0 \\
\hline $\mathrm{CSCO}$ & $\begin{array}{c}\text { CISCO } \\
\text { SYSTEMS INC }\end{array}$ & $\begin{array}{c}\text { Cisco enables people to make powerful connections - whether in business, } \\
\text { education, philanthropy, or creativity. Cisco hardware, software, and } \\
\text { service offerings are used to create the Internet solutions that make } \\
\text { networks possible-providing easy access to information anywhere, at any } \\
\text { time." }\end{array}$ & & 0 \\
\hline CVX & $\begin{array}{l}\text { CHEVRON } \\
\text { CORP }\end{array}$ & $\begin{array}{l}\text { Our Company's foundation is built on our Values, which distinguish us and } \\
\text { guide our actions. We conduct our business in a socially responsible and } \\
\text { ethical manner. We respect the law, support universal human rights, } \\
\text { protect the environment, and benefit the communities where we work." }\end{array}$ & $\begin{array}{c}\text { At the heart of The } \\
\text { Chevron Way is } \\
\text { our vision ...to be } \\
\text { the global energy } \\
\text { company most } \\
\text { admired for its } \\
\text { people, } \\
\text { partnership and } \\
\text { performance }\end{array}$ & 1 \\
\hline
\end{tabular}




\begin{tabular}{|c|c|c|c|}
\hline DAN & $\begin{array}{l}\text { DANA } \\
\text { HOLDING } \\
\text { CORP }\end{array}$ & $\begin{array}{l}\text { Our vision is for Dana to operate efficiently as one integrated company } \\
\text { focused on growing our core light and heavy-drive train products, } \\
\text { structures, thermal and sealing businesses. This refocused product array } \\
\text { will help us better support our global automotive, commercial vehicle, and } \\
\text { off-highway markets. Our vision also includes achieving much stronger } \\
\text { cost and operating levels, which will enable us to prosper and grow }\end{array}$ & 0 \\
\hline $\mathrm{DE}$ & DEERE \& CO & $\begin{array}{l}\text { John Deere's mission is to "Double and Double Again the John Deere } \\
\text { Experience of Genuine Value for Employees, Customers, and } \\
\text { Shareholders." This will be accomplished by rapidly expanding global } \\
\text { customer coverage on the farmsite, worksite, homesite, and turfsite by } \\
\text { being first in creating smart and innovative customer solutions through } \\
\text { machines, service, and concepts. The company's business strategies of } \\
\text { Running Smart, Running Fast, and Running Lean will help John Deere } \\
\text { achieve its mission }\end{array}$ & 0 \\
\hline DELL & DELL INC & $\begin{array}{c}\text { Dell is committed to being a good neighbor in the communities we call home. } \\
\text { We must continue to grow responsibly - protecting our natural resources } \\
\text { and practicing sustainability in all its forms - and improve the } \\
\text { communities where we live and work through our financial and volunteer } \\
\text { efforts }\end{array}$ & 1 \\
\hline DF & $\begin{array}{l}\text { DEAN FOODS } \\
\text { CO }\end{array}$ & $\begin{array}{c}\text { The Company's primary objective is to maximize long-term stockholder } \\
\text { value, while adhering to the laws of the jurisdictions in which it operates } \\
\text { and at all times observing the highest ethical standards }\end{array}$ & 1 \\
\hline DHR & $\begin{array}{l}\text { DANAHER } \\
\text { CORP }\end{array}$ & $\begin{array}{c}\text { We base our strategic plan on the Voice-of-the-Customer. Robust, repeatable } \\
\text { processes yield superior Quality, Delivery, and Cost that satisfy our } \\
\text { customers beyond their expectations }\end{array}$ & 0 \\
\hline $\mathrm{DOV}$ & DOVER CORP & $\begin{array}{c}\text { Our goal is to be the leader in every market we serve, to the benefit of our } \\
\text { customers and our shareholders. " }\end{array}$ & 0 \\
\hline DOW & $\begin{array}{c}\text { DOW } \\
\text { CHEMICAL }\end{array}$ & $\begin{array}{c}\text { To constantly improve what is essential to human progress by mastering } \\
\text { science and technology }\end{array}$ & 0 \\
\hline
\end{tabular}




\begin{tabular}{|c|c|c|c|c|}
\hline ECL & ECOLAB INC & $\begin{array}{l}\text { Our mission is to be the leading global innovator, developer and provider of } \\
\text { cleaning, sanitation and maintenance products, systems, and services. As a } \\
\text { team, we will achieve aggressive growth and fair return for our } \\
\text { shareholders. We will accomplish this by exceeding the expectations of our } \\
\text { customers while conserving resources and preserving the quality of the } \\
\text { environment }\end{array}$ & & 1 \\
\hline EK & $\begin{array}{l}\text { EASTMAN } \\
\text { KODAK CO }\end{array}$ & $\begin{array}{c}\text { At Kodak, we believe that by doing well by shareholders also means doing } \\
\text { right by customers, employees, neighbors, and suppliers. With that in } \\
\text { mind, Kodak operates its facilities, and designs and markets its products } \\
\text { and services, not only to increase shareholder value, but also to promote } \\
\text { development of the individual, the well being of the community, and } \\
\text { respect for the environment }\end{array}$ & & 1 \\
\hline$\overline{E L}$ & $\begin{array}{l}\text { LAUDER } \\
\text { (ESTEE) COS } \\
\text { INC -CL A }\end{array}$ & & $\begin{array}{c}\text { Bringing the best to } \\
\text { everyone we } \\
\text { touch". By "The } \\
\text { best", we mean } \\
\text { the best products, } \\
\text { the best people } \\
\text { and the best ideas. } \\
\text { These three pillars } \\
\text { have been the } \\
\text { hallmarks of our } \\
\text { Company since it } \\
\text { was founded by } \\
\text { Mrs. Estee Lauder } \\
\text { in 1946. They } \\
\text { remain the } \\
\text { foundation upon } \\
\text { which we } \\
\text { continue to build } \\
\text { our success today. }\end{array}$ & 0 \\
\hline EMC & EMC CORP/MA & $\begin{array}{l}\text { We believe that information is a business's most important asset. Ideas-and } \\
\text { the people who come up with them-are the only real differentiator. Our } \\
\text { promise is to help you take that differentiator as far as possible. We will } \\
\text { deliver on this promise by helping organizations of all sizes manage more } \\
\text { information more effectively than ever before. We will provide solutions }\end{array}$ & & 0 \\
\hline
\end{tabular}




\begin{tabular}{|c|c|c|c|c|}
\hline & & $\begin{array}{l}\text { that meet and exceed your most demanding business and IT challenges. } \\
\text { We will bring your information to life." }\end{array}$ & & \\
\hline EMN & $\begin{array}{c}\text { EASTMAN } \\
\text { CHEMICAL CO }\end{array}$ & $\begin{array}{l}\text { It takes more than bricks and mortar to make a company great. Technology, } \\
\text { quality, manufacturing excellence, customer service - these are a few of } \\
\text { Eastman's strengths. But it's the men and women of Eastman who are the } \\
\text { common element in these attributes. They are the key to our success. } \\
\text { Teamwork, quality and safety are core values that are engrained in the } \\
\text { Eastman culture. We recognize the importance of treating each other, as } \\
\text { well as those around us, with fairness and respect. We strive for quality in } \\
\text { everything we do - from producing products to building relationships. And } \\
\text { we are committed to operating safely while protecting people and the } \\
\text { environment }\end{array}$ & & 1 \\
\hline EMR & $\begin{array}{l}\text { EMERSON } \\
\text { ELECTRIC CO }\end{array}$ & $\begin{array}{l}\text { Emerson is where technology and engineering come together to create } \\
\text { solutions for the benefit of our customers, driven without compromise for a } \\
\text { world in action }\end{array}$ & & 0 \\
\hline ETN & EATON CORP & $\begin{array}{l}\text { "We are committed to attracting, developing, and keeping a diverse work force } \\
\text { that reflects the nature of our global business." }\end{array}$ & & 0 \\
\hline $\mathrm{F}$ & $\begin{array}{l}\text { FORD MOTOR } \\
\text { CO }\end{array}$ & $\begin{array}{l}\text { We are a global family with a proud heritage passionately committed to } \\
\text { providing personal mobility for people around the world." }\end{array}$ & & 0 \\
\hline FO & $\begin{array}{l}\text { FORTUNE } \\
\text { BRANDS INC }\end{array}$ & $\begin{array}{l}\text { Our foundation is a business model that creates shareholder value by building } \\
\text { consumer brands and consumer-brand businesses in attractive, high-return } \\
\text { categories. To fuel sustainable sales growth and outperform our markets, } \\
\text { we invest in building the equity of our brands and in developing the next } \\
\text { generation of must-have products." }\end{array}$ & $\begin{array}{c}\text { We create additional } \\
\text { growth } \\
\text { opportunities for } \\
\text { our brands by } \\
\text { investing to } \\
\text { expand into new } \\
\text { markets, including } \\
\text { adjacent product } \\
\text { categories and } \\
\text { untapped } \\
\text { international } \\
\text { markets. To boost }\end{array}$ & 0 \\
\hline
\end{tabular}




\begin{tabular}{|c|c|c|c|c|}
\hline & & & $\begin{array}{c}\text { our asset returns, } \\
\text { productivity and } \\
\text { customer service, } \\
\text { we invest in lean, } \\
\text { flexible global } \\
\text { supply chains and } \\
\text { streamlined } \\
\text { business } \\
\text { processes." }\end{array}$ & \\
\hline FTI & $\begin{array}{c}\text { FMC } \\
\text { TECHNOLOGIE } \\
\text { S INC }\end{array}$ & $\begin{array}{l}\text { FMC Technologies, Inc. is a leading global provider of technology solutions } \\
\text { for the energy industry and other industrial markets. The Company } \\
\text { designs, manufactures and services technologically sophisticated systems } \\
\text { and products such as subsea production and processing systems, surface } \\
\text { wellhead systems, high pressure fluid control equipment, measurement } \\
\text { solutions, and marine loading systems for the oil and gas industry }\end{array}$ & & 0 \\
\hline GD & $\begin{array}{c}\text { GENERAL } \\
\text { DYNAMICS } \\
\text { CORP }\end{array}$ & $\begin{array}{l}\text { General Dynamics focuses on creating shareholder value while delivering } \\
\text { superior products and services to military, other government and } \\
\text { commercial customers. The company emphasizes excellence in program } \\
\text { management and continual improvement in all of its operations. }\end{array}$ & & 0 \\
\hline GIS & $\begin{array}{l}\text { GENERAL } \\
\text { MILLS INC }\end{array}$ & $\begin{array}{c}\text { Our Values We reinforce our values everyday through our people, our brands, } \\
\text { our innovation and our performance. Championship Brands ... building } \\
\text { leading brands that our consumers trust around the world } \\
\text { - making lives easier, healthier and more fun. Championship People ... } \\
\text { diverse, talented, committed people - constantly learning and growing and } \\
\text { contributing to our communities. Championship Innovation ... developing } \\
\text { and implementing innovative ideas to build our brands and drive our } \\
\text { business. Championship Performance ... delivering outstanding } \\
\text { performance for our investors, our customers, our consumers and } \\
\text { ourselves." }\end{array}$ & & 1 \\
\hline
\end{tabular}




\begin{tabular}{|c|c|c|c|c|}
\hline GLW & CORNING INC & $\begin{array}{c}\text { Corning Incorporated, the world leader in specialty glass and ceramics, has } \\
\text { worked closely with customers to understand their problems, explore } \\
\text { possible solutions, and then bring those solutions to life through our world- } \\
\text { class scientific and manufacturing capabilities." }\end{array}$ & & 0 \\
\hline GR & $\begin{array}{l}\text { GOODRICH } \\
\text { CORP }\end{array}$ & $\begin{array}{l}\text { Goodrich offers an extensive range of products, systems and services for } \\
\text { aircraft and engine manufacturers, airlines and defense forces around the } \\
\text { world. The company's transformation into one of the globe's largest } \\
\text { aerospace companies has been driven by strategic acquisitions and internal } \\
\text { growth fuelled by innovation and quality }\end{array}$ & & 0 \\
\hline GRMN & GARMIN LTD & $\begin{array}{l}\text { Garmin's mission is to enrich the lives of its customers, } \\
\text { suppliers, distributors, employees and stockholders by } \\
\text { designing, manufacturing and selling navigation and } \\
\text { communication products that provide superior quality, } \\
\text { safety and operational features, lower cost of } \\
\text { manufacturing and ownership, and sufficient profits to } \\
\text { support desired company growth." }\end{array}$ & & 0 \\
\hline GSK & $\begin{array}{l}\text { GLAXOSMITHK } \\
\text { LINE PLC }\end{array}$ & $\begin{array}{l}\text { We have a challenging and inspiring mission to improve the quality of human } \\
\text { life by enabling people to do more, feel better and live longer }\end{array}$ & & 0 \\
\hline GT & $\begin{array}{c}\text { GOODYEAR } \\
\text { TIRE \& } \\
\text { RUBBER CO }\end{array}$ & Goodyear's mission is to be the number one tire company by all measures. & & 0 \\
\hline HAS & HASBRO INC & $\begin{array}{l}\text { The health and safety services of Hasbro promotes an atmosphere which } \\
\text { supports the maintenance of employee health; the prevention, detection, } \\
\text { treatment, and rehabilitation of employees, consultation with management } \\
\text { in } \\
\text { health related issues; and the continuing education and professional growth } \\
\text { of the occupational health and safety staff }\end{array}$ & $\begin{array}{l}\text { The mission is to } \\
\text { provide Hasbro } \\
\text { Inc. with } \\
\text { professional } \\
\text { safety health, } \\
\text { environmental } \\
\text { loss } \\
\text { prevention } \\
\text { services for the }\end{array}$ & 1 \\
\hline
\end{tabular}




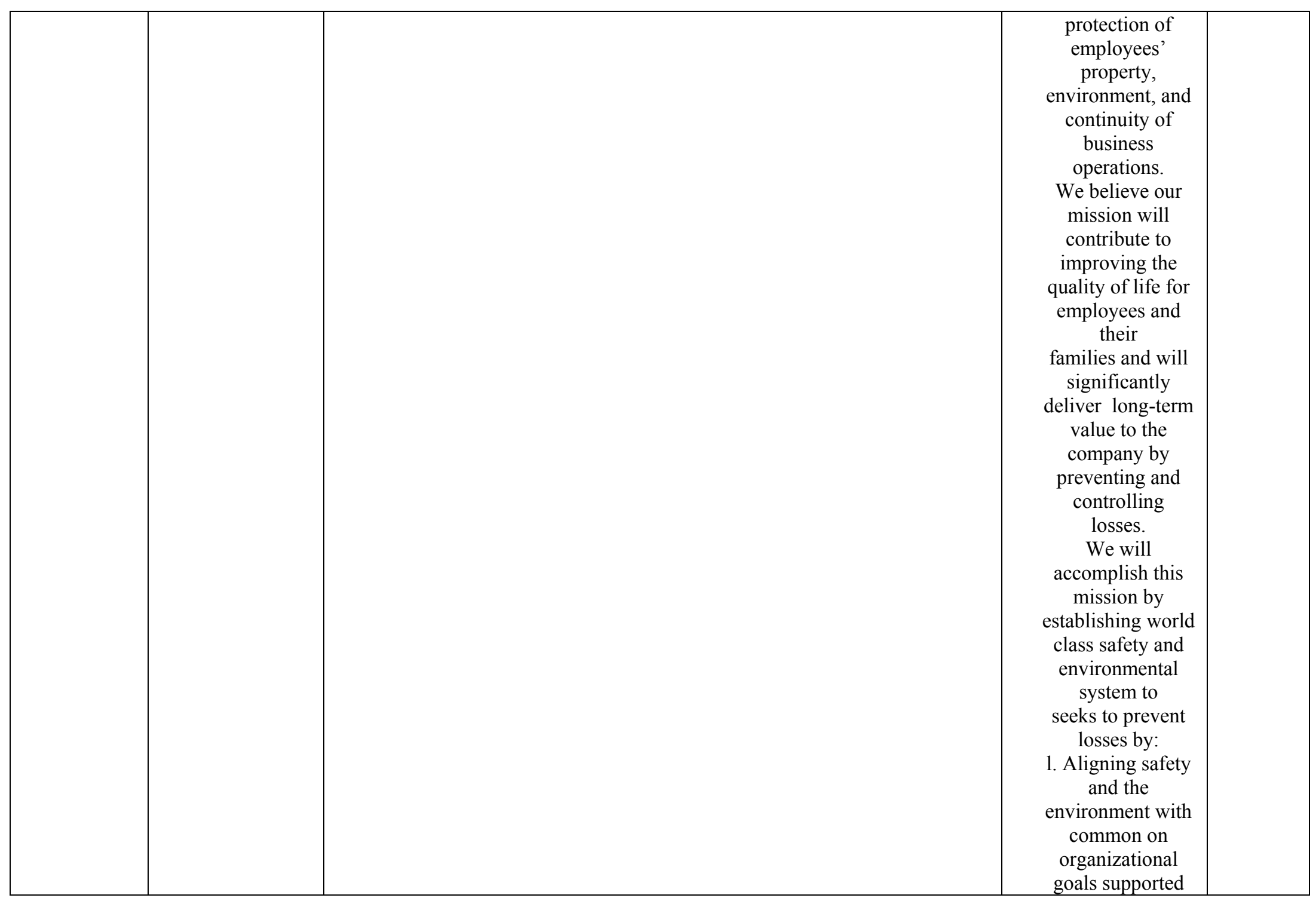




\begin{tabular}{|c|c|c|c|c|}
\hline & & & $\begin{array}{c}\text { by } \\
\text { company values. } \\
\text { 2. Providing } \\
\text { continuous } \\
\text { improvement } \\
\text { process and } \\
\text { strategy to drives } \\
\text { the company } \\
\text { towards } \\
\text { achieving safety } \\
\text { an d } \\
\text { environmental } \\
\text { excellence. etc. }\end{array}$ & \\
\hline HBI & $\begin{array}{l}\text { HANESBRAND } \\
\text { S INC }\end{array}$ & $\begin{array}{l}\text { Hanesbrands Inc.'s mission is to profitably grow our leading brands by } \\
\text { intimately understanding our consumers, by out-executing our competition } \\
\text { and by leveraging our sustainable competitive advantage. Our vision is to } \\
\text { be a world-class consumer goods company with a distinctive competence } \\
\text { in operating a low-cost, global supply chain }\end{array}$ & & 0 \\
\hline HES & HESS CORP & $\begin{array}{c}\text { To maximize shareholder value by enhancing financial performance and } \\
\text { providing long-term profitable growth }\end{array}$ & & 0 \\
\hline
\end{tabular}




\begin{tabular}{|c|c|c|c|c|}
\hline $\mathrm{HNZ}$ & HEINZ (H J) CO & $\begin{array}{l}\text { As the trusted leader in nutrition and wellness, Heinz - the original Pure Food } \\
\text { Company - is dedicated to the sustainable health of people, the planet and } \\
\text { our Company. } \\
\text { Heinz Values: } \\
\text {-Team Building \& Collaboration - We embrace great ideas from } \\
\text { everywhere and everyone and respect all individuals. } \\
\text {-Innovation - We spot consumer and customer needs and meet them with } \\
\text { simple, creative solutions. } \\
\text {-Vision - We define a compelling, sustainable future and create the path to } \\
\text { achieve it. } \\
\text {-Results - We deliver on commitments, take accountability and balance the } \\
\text { short- and long-term. } \\
\text {-Integrity - We always tell the truth, act with the highest ethical standards } \\
\text { and ensure that our products are of the highest quality. }\end{array}$ & & 1 \\
\hline $\mathrm{HOG}$ & $\begin{array}{l}\text { HARLEY- } \\
\text { DAVIDSON INC }\end{array}$ & $\begin{array}{l}\text { We fulfill dreams through the experience of motorcycling, by providing to } \\
\text { motorcyclists and to the general public an expanding line of motorcycles } \\
\text { and branded products and services in selected market segments }\end{array}$ & & 0 \\
\hline $\mathrm{HON}$ & $\begin{array}{l}\text { HONEYWELL } \\
\text { INTERNATION } \\
\text { AL INC }\end{array}$ & $\begin{array}{l}\text { to continuously improve the way we do things so that we can capture greater } \\
\text { value not just for us, but also for our customers }\end{array}$ & & 0 \\
\hline HPQ & $\begin{array}{l}\text { HEWLETT- } \\
\text { PACKARD CO }\end{array}$ & $\begin{array}{l}\text { To provide products, services and solutions of the highest quality and deliver } \\
\text { more value to our customers that earns their respect and loyalty." }\end{array}$ & \begin{tabular}{|c} 
To view change in the \\
market as an \\
opportunity to \\
grow; to use our \\
profits and our \\
ability to develop \\
and produce \\
innovative \\
products, services \\
and solutions that \\
satisfy emerging \\
customer needs."
\end{tabular} & 0 \\
\hline
\end{tabular}




\begin{tabular}{|c|c|c|c|c|}
\hline HRL & $\begin{array}{c}\text { HORMEL } \\
\text { FOODS CORP }\end{array}$ & $\begin{array}{l}\text { As a leading branded food company with a focus on profitable growth and } \\
\text { inspired by our founder's charge to "Originate, don't imitate," we market a } \\
\text { balanced portfolio of highly differentiated quality products. }\end{array}$ & $\begin{array}{c}\text { As a leading branded } \\
\text { food company } \\
\text { with a focus on } \\
\text { profitable growth } \\
\text { and inspired by } \\
\text { our founder's } \\
\text { charge to } \\
\text { "Originate, don't } \\
\text { imitate," we } \\
\text { market a balanced } \\
\text { portfolio of highly } \\
\text { differentiated } \\
\text { quality products }\end{array}$ & 0 \\
\hline
\end{tabular}




\begin{tabular}{|c|c|c|c|c|}
\hline HRS & HARRIS CORP & $\begin{array}{l}\text { Harris Corporation will be the best-in-class global provider of mission-critical } \\
\text { assured communications systems and services to both government and } \\
\text { commercial customers, combining advanced technology and application } \\
\text { knowledge to offer a superior value proposition }\end{array}$ & $\begin{array}{l}\text { As a complement to } \\
\text { the mission, a } \\
\text { common set of } \\
\text { corporate-wide } \\
\text { values will drive how } \\
\text { our employees } \\
\text { conduct themselves } \\
\text { in shaping the } \\
\text { difference toward } \\
\text { achieving our } \\
\text { mission. } \\
\text {-Integrity - We all } \\
\text { have a desire for our } \\
\text { business to succeed } \\
\text { and grow, and we do } \\
\text { not compromise our } \\
\text { values to achieve that } \\
\text { success. } \\
\text { •Delivering Customer } \\
\text { Value - We value } \\
\text { customer focus in all } \\
\text { that we do. } \\
\text { •Collaboration/Team } \\
\text { work/Global } \\
\text { Inclusion - We } \\
\text { realize that more } \\
\text { creative solutions and } \\
\text { success comes from } \\
\text { working together and } \\
\text { supporting each other } \\
\text { to achieve our goals. } \\
\text { This collaboration } \\
\text { extends across all } \\
\text { areas of our business } \\
\text { - throughout the } \\
\text { entire organization. }\end{array}$ & 0 \\
\hline
\end{tabular}




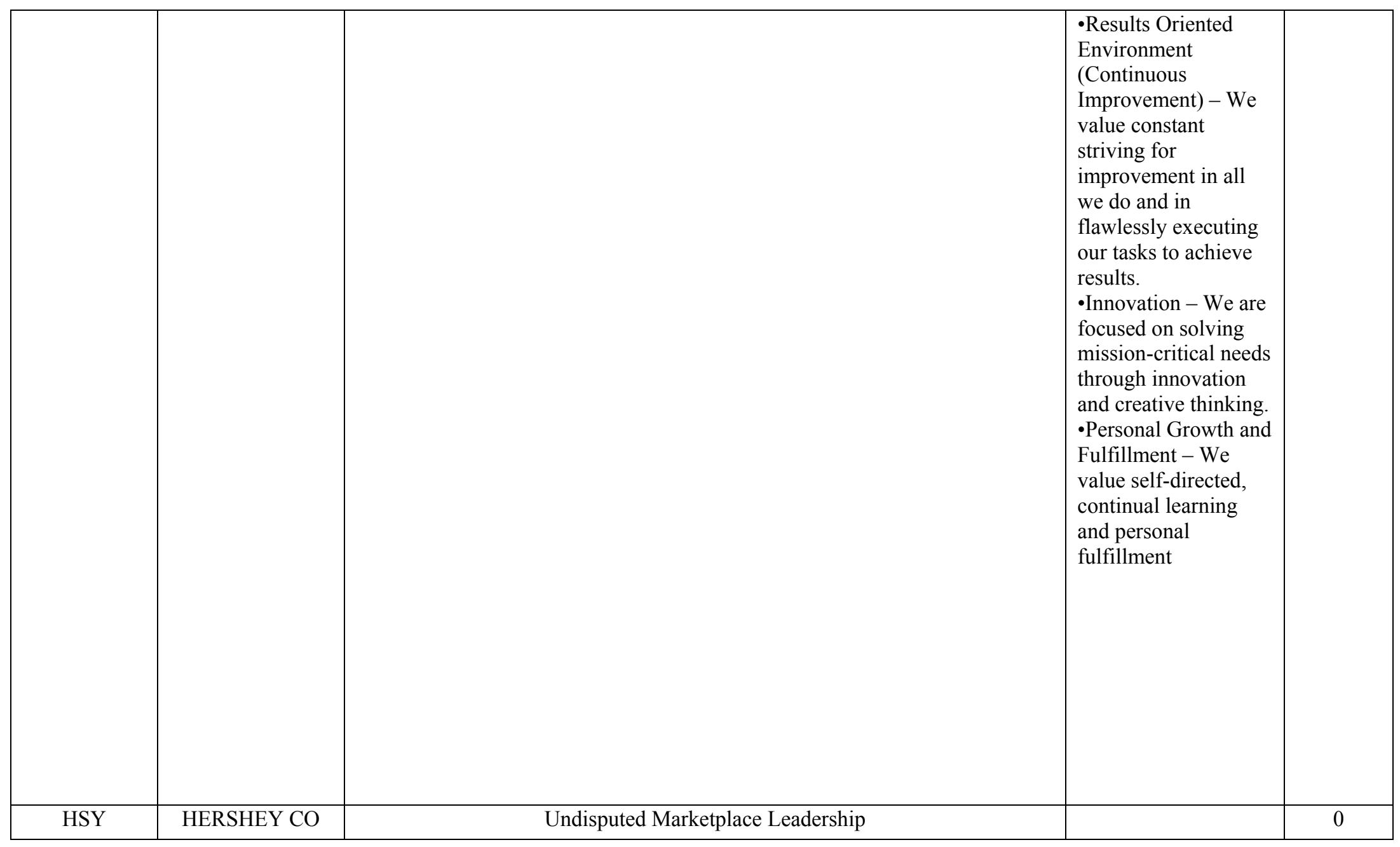




\begin{tabular}{|c|c|c|c|c|}
\hline HUN & $\begin{array}{l}\text { HUNTSMAN } \\
\text { CORP }\end{array}$ & $\begin{array}{c}\text { We will operate safe, clean, efficient facilities in an environmentally and } \\
\text { socially responsible manner. } \\
\text { We will provide a work environment that fosters teamwork, innovation, } \\
\text { accountability and open communication. } \\
\text { We will place into society assistance for those who suffer, hope for those } \\
\text { who may need inspiration and education for those who may feel the } \\
\text { challenge but do not have the means }\end{array}$ & $\begin{array}{c}\text { Ne have an aggressive } \\
\text { growth } \\
\text { philosophy which } \\
\text { reflects the spirit } \\
\text { of free enterprise } \\
\text { and maximization } \\
\text { of long term } \\
\text { profits, the best } \\
\text { motives for } \\
\text { creating mutual } \\
\text { benefits for } \\
\text { customers, } \\
\text { employees, } \\
\text { suppliers and the } \\
\text { communities in } \\
\text { which we are } \\
\text { located }\end{array}$ & 1 \\
\hline INTC & INTEL CORP & $\begin{array}{l}\text { Delight our customers, employees, and shareholders by relentlessly delivering } \\
\text { the platform and technology advancements that become essential to the } \\
\text { way we work and live }\end{array}$ & & 0 \\
\hline IP & INTL PAPER CO & $\begin{array}{l}\text { International Paper is dedicated to making people's lives better. Our } \\
\text { employees use renewable resources to make products people depend on } \\
\text { every day. Our customers succeed because our innovative products and } \\
\text { services make their businesses better. Our communities welcome us as } \\
\text { neighbors, employers and environmental stewards. Our shareowners } \\
\text { benefit from our superior financial performances. By keeping our } \\
\text { promises, we deliver results. }\end{array}$ & $\begin{array}{c}\text { International Paper } \\
\text { will be one of the } \\
\text { best and most } \\
\text { respected } \\
\text { companies in the } \\
\text { world - as } \\
\text { measured by our } \\
\text { employees, our } \\
\text { customers, our } \\
\text { communities and } \\
\text { our shareowners }\end{array}$ & 1 \\
\hline
\end{tabular}




\begin{tabular}{|c|c|c|c|}
\hline IR & $\begin{array}{l}\text { INGERSOLL- } \\
\text { RAND PLC }\end{array}$ & 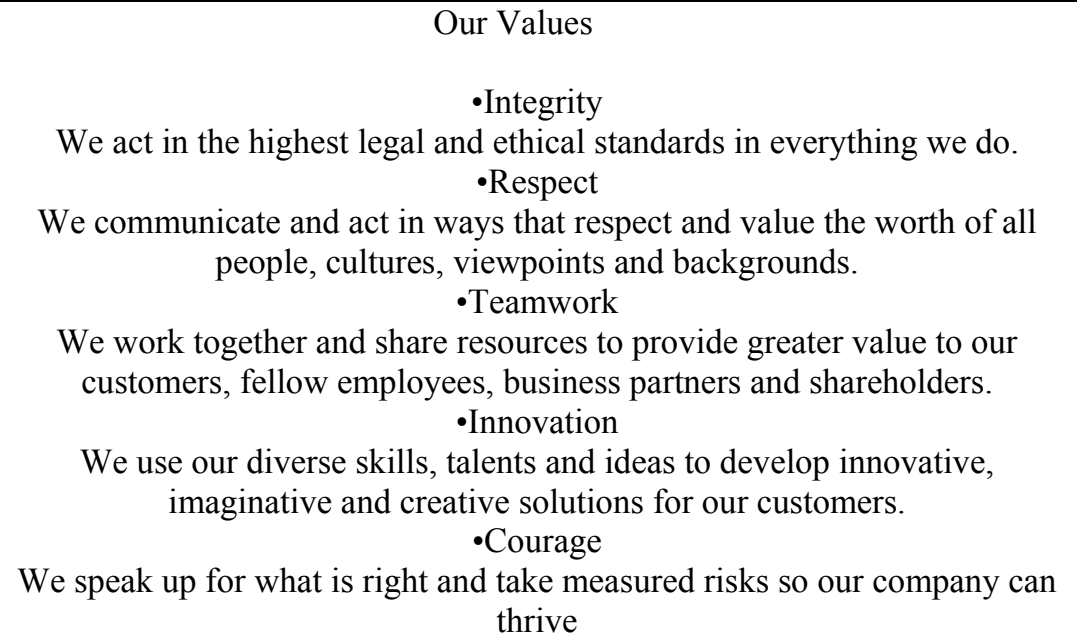 & 1 \\
\hline ITT & ITT CORP & $\begin{array}{l}\text { ITT is a vibrant part of the global economy. We are a high-technology } \\
\text { engineering and manufacturing company with approximately 40,000 } \\
\text { employees operating in } 55 \text { countries. Our portfolio of businesses is aligned } \\
\text { with enduring, global growth drivers, and our employees bring } \\
\text { extraordinary focus to meeting the needs of the people who buy and use } \\
\text { our products and } \\
\text { services in all the markets we serve." }\end{array}$ & 0 \\
\hline ITW & $\begin{array}{c}\text { ILLINOIS TOOL } \\
\text { WORKS }\end{array}$ & $\begin{array}{l}\text { We believe the future of good business is deeply rooted in the past. By } \\
\text { following our guiding principles designed to enhance customer focus, } \\
\text { productivity, innovation and profitability, we are able to make continual } \\
\text { process and product improvements for customers, while producing solid } \\
\text { results for our shareholders. Our ability to produce commercial innovations } \\
\text { on a continual basis for our customers is the foundation of our success.Our } \\
\text { main guiding principles include the following: Decentralization } 80 / 20 \\
\text { Process, Innovation }\end{array}$ & 0 \\
\hline
\end{tabular}




\begin{tabular}{|c|c|c|c|}
\hline JAH & JARDEN CORP & $\begin{array}{l}\text { Our objective is to build a world-class consumer products company that } \\
\text { enjoys leading positions in markets for branded consumer products. We } \\
\text { will seek to achieve this objective by continuing our tradition of product } \\
\text { innovation, new product introductions and providing the consumer with the } \\
\text { experience and value they associate with our brands. We plan to leverage } \\
\text { and expand our domestic and international distribution channels, increase } \\
\text { brand awareness through co-branding and cross selling initiatives and } \\
\text { pursue strategic acquisitions, all while driving margin improvement." }\end{array}$ & 0 \\
\hline JBL & $\begin{array}{c}\text { JABIL CIRCUIT } \\
\text { INC }\end{array}$ & $\begin{array}{l}\text { Our goal is to achieve customer satisfaction through excellence in design, } \\
\text { supply chain management, manufacturing and repair solutions. Through } \\
\text { our culture, our drive and the expertise of each individual employee, we } \\
\text { are uniquely positioned to provide best-in-class services to a global } \\
\text { customer base }\end{array}$ & 0 \\
\hline JCI & $\begin{array}{c}\text { JOHNSON } \\
\text { CONTROLS INC }\end{array}$ & Continually exceed our customers' increasing expectations & 0 \\
\hline JNJ & $\begin{array}{c}\text { JOHNSON \& } \\
\text { JOHNSON }\end{array}$ & $\begin{array}{l}\text { We believe our first responsibility is to the doctors, nurses and patients, to } \\
\text { mothers and fathers and all others who use our products and services. In } \\
\text { meeting their needs everything we do must be of high quality. We must } \\
\text { constantly strive to reduce our costs in order to maintain reasonable prices. } \\
\text { Customers' orders must be serviced promptly and accurately. Our suppliers } \\
\text { and distributors must have an opportunity to make a fair profit. We are } \\
\text { responsible to our employees, the men and women who work with us } \\
\text { throughout the world. Everyone must be considered as an individual. We } \\
\text { must respect their dignity and recognize their merit. They must have a } \\
\text { sense of security in their jobs. Compensation must be fair and adequate, } \\
\text { and working conditions clean, orderly and safe. We must be mindful of } \\
\text { ways to help our employees fulfill their family responsibilities. Employees } \\
\text { must feel free to make suggestions and complaints. There must be equal } \\
\text { opportunity for employment, development and advancement for those } \\
\text { qualified. We must provide competent management, and their actions must } \\
\text { be just and ethical. We are responsible to the communities in which we live } \\
\text { and work and to the world community as well. We must be good citizens - } \\
\text { support good works and charities and bear our fair share of taxes. We must }\end{array}$ & 1 \\
\hline
\end{tabular}




\begin{tabular}{|c|c|c|c|}
\hline & & $\begin{array}{l}\text { encourage civic improvements and better health and education. We must } \\
\text { maintain in good order the property we are privileged to use, protecting the } \\
\text { environment and natural resources. Our final responsibility is to our } \\
\text { stockholders. Business must make a sound profit. We must experiment } \\
\text { with new ideas. Research must be carried on, innovative programs } \\
\text { developed and mistakes paid for. New equipment must be purchased, new } \\
\text { facilities provided and new products launched. Reserves must be created to } \\
\text { provide for adverse times. When we operate according to these principles, } \\
\text { the stockholders should realize a fair return }\end{array}$ & \\
\hline JNPR & $\begin{array}{l}\text { JUNIPER } \\
\text { NETWORKS } \\
\text { INC }\end{array}$ & $\begin{array}{l}\text { Maximize shareholder value for Juniper Networks investors by } \\
\text { communicating and educating the financial community - the company's } \\
\text { vision, business objectives and performance. }\end{array}$ & 0 \\
\hline $\mathrm{K}$ & KELLOGG CO & $\begin{array}{l}\text { Kellogg is a global company committed to building long-term growth in } \\
\text { volume and profit and to enhancing its worldwide leadership position by } \\
\text { providing nutritious food products of superior value. How do we uphold } \\
\text { this mission? Our world-class leadership is dedicated to a management } \\
\text { philosophy that holds people above profits. And they're committed to an } \\
\text { advertising and marketing philosophy that helps ensure the Kellogg name } \\
\text { is associated with wholesome, truthful advertising.". }\end{array}$ & 0 \\
\hline KFT & $\begin{array}{c}\text { KRAFT FOODS } \\
\text { INC }\end{array}$ & Helping People Around the World Eat and Live Better & 0 \\
\hline KMB & $\begin{array}{l}\text { KIMBERLY- } \\
\text { CLARK CORP }\end{array}$ & $\begin{array}{c}\text { Kimberly-Clark has adhered to a set of simple yet insightful values established } \\
\text { by our founders - quality, service and fair dealing. These are the standards } \\
\text { of performance by which our leadership and employees are measured. } \\
\text { These values have helped establish Kimberly-Clark as a leading-edge } \\
\text { global company that produces superior health and hygiene products used } \\
\text { by families and professionals from all walks of life and cultures around the } \\
\text { world }\end{array}$ & 0 \\
\hline
\end{tabular}




\begin{tabular}{|c|c|c|c|c|}
\hline $\mathrm{KO}$ & $\begin{array}{c}\text { COCA-COLA } \\
\text { CO }\end{array}$ & $\begin{array}{l}\text { Our mission declares our purpose as a company. It serves as the standard } \\
\text { against which we weigh our actions and decisions. It is the foundation of } \\
\text { our Manifesto. To refresh the world in body, mind and spirit. To inspire } \\
\text { moments of optimism through our brands and our actions. } \\
\text { To create value and make a difference everywhere we engage }\end{array}$ & $\begin{array}{l}\text { Our vision guides } \\
\text { every aspect of our } \\
\text { business by } \\
\text { describing what we } \\
\text { need to accomplish in } \\
\text { order to continue } \\
\text { achieving sustainable } \\
\text { growth. People: } \\
\text { Being a great place to } \\
\text { work where people } \\
\text { are inspired to be the } \\
\text { best they can be. } \\
\text { Portfolio: Bringing to } \\
\text { the world a portfolio } \\
\text { of quality beverage } \\
\text { brands that anticipate } \\
\text { and satisfy people's } \\
\text { desires and needs. } \\
\text { Partners: Nurturing a } \\
\text { winning network of } \\
\text { customers and } \\
\text { suppliers, together we } \\
\text { create mutual, } \\
\text { enduring value. } \\
\text { Planet: Being a } \\
\text { responsible citizen } \\
\text { that makes a } \\
\text { difference by helping } \\
\text { build and support } \\
\text { sustainable } \\
\text { communities. Profit: } \\
\text { Maximizing long- } \\
\text { term return to } \\
\text { shareowners while } \\
\text { being mindful of our } \\
\text { overall } \\
\text { responsibilities }\end{array}$ & 1 \\
\hline
\end{tabular}




\begin{tabular}{|c|c|c|c|c|}
\hline LEA & LEAR CORP & $\begin{array}{l}\text { The success of Lear is a result of our dedication to provide the best possible } \\
\text { service to the world's automakers - which includes understanding their } \\
\text { customers, the automotive consumer - by delivering increased value } \\
\text { through the latest vehicle interior technologies and the continuous } \\
\text { improvement of our processes and product quality }\end{array}$ & & 0 \\
\hline LEG & $\begin{array}{l}\text { LEGGETT \& } \\
\text { PLATT INC }\end{array}$ & $\begin{array}{l}\text { Through continuous improvement, we will provide customers with innovative } \\
\text { solutions that support their long term profitable growth. We will provide } \\
\text { high quality products that meet or exceed their expectations. We will } \\
\text { eliminate non-value added costs from our products and processes, while } \\
\text { finding new work methods that are simpler, safer and more rewarding." }\end{array}$ & & 0 \\
\hline LIFE & $\begin{array}{l}\text { LIFE } \\
\text { TECHNOLOGIE } \\
\text { S CORP }\end{array}$ & $\begin{array}{c}\text { is committed to restoring the patient's quality of life by developing, } \\
\text { manufacturing and marketing products that are unsurpassed in quality and } \\
\text { performance. }\end{array}$ & & 0 \\
\hline LLY & $\begin{array}{c}\text { LILLY (ELI) \& } \\
\text { CO }\end{array}$ & $\begin{array}{l}\text { We pursue pharmaceutical innovation, provide high-quality products, and } \\
\text { strive to deliver superior business results. We continually search for new } \\
\text { ways to improve everything we do. " }\end{array}$ & & 0 \\
\hline LMT & $\begin{array}{c}\text { LOCKHEED } \\
\text { MARTIN CORP }\end{array}$ & $\begin{array}{l}\text { We assist LM companies to obtain product sales financing that (a) fits their } \\
\text { customer's economic profiles, (b) uses financing strategies tailored to each } \\
\text { market, and (c) protects Lockheed Martin Corporation. We utilize our } \\
\text { expertise to develop services that add value at each phase of the LM } \\
\text { business development cycle. We evaluate and implement new strategies in } \\
\text { response to changing customer profiles and market conditions. }\end{array}$ & $\begin{array}{c}\text { owered By Innovation, } \\
\text { Guided By } \\
\text { Integrity, We } \\
\text { Help Our } \\
\text { Customers } \\
\text { Achieve Their } \\
\text { Most Challenging } \\
\text { Goals." }\end{array}$ & 0 \\
\hline
\end{tabular}




\begin{tabular}{|c|c|c|c|c|}
\hline MAS & MASCO CORP & $\begin{array}{l}\text { Commitment to Quality and Excellence } \\
\text { Driven by a focus on excellence in people, products, service, and } \\
\text { partnering relationships, Masco remains committed to being a premier } \\
\text { growth company - a commitment that has resulted in above-average } \\
\text { increases in earnings and value to shareholders." }\end{array}$ & & 0 \\
\hline MAT & MATTEL INC & To be the premier Toy Brands - today and tomorrow & $\begin{array}{l}\text { Mattel makes a } \\
\text { difference in the } \\
\text { global community by } \\
\text { effectively serving } \\
\text { children in need . } \\
\text { Partnering with } \\
\text { charitable } \\
\text { organizations } \\
\text { dedicated to directly } \\
\text { serving children, } \\
\text { Mattel creates joy } \\
\text { through the Mattel } \\
\text { Children's } \\
\text { Foundation, product } \\
\text { donations, grant } \\
\text { making and the work } \\
\text { of employee } \\
\text { volunteers. We also } \\
\text { enrich the lives of } \\
\text { Mattel employees by } \\
\text { identifying diverse } \\
\text { volunteer } \\
\text { opportunities and } \\
\text { supporting their } \\
\text { personal } \\
\text { contributions through } \\
\text { the matching gifts } \\
\text { program. }\end{array}$ & 1 \\
\hline
\end{tabular}




\begin{tabular}{|c|c|c|c|}
\hline MDT & $\begin{array}{l}\text { MEDTRONIC } \\
\text { INC }\end{array}$ & $\begin{array}{l}\text { To contribute to human welfare by application of biomedical engineering in } \\
\text { the research, design, manufacture, and sale of instruments or appliances } \\
\text { that alleviate pain, restore health, and extend life. To direct our growth in } \\
\text { the areas of biomedical engineering where we display maximum strength } \\
\text { and ability; to gather people and facilities that tend to augment these areas; } \\
\text { to continuously build on these areas through education and knowledge } \\
\text { assimilation; to avoid participation in areas where we cannot make unique } \\
\text { and worthy contributions. To strive without reserve for the greatest } \\
\text { possible reliability and quality in our products; to be the unsurpassed } \\
\text { standard of comparison and to be recognized as a company of dedication, } \\
\text { honesty, integrity, and service. To make a fair profit on current operations } \\
\text { to meet our obligations, sustain our growth, and reach our goals. To } \\
\text { recognize the personal worth of employees by providing an employment } \\
\text { framework that allows personal satisfaction in work accomplished, } \\
\text { security, advancement opportunity, and means to share in the company's } \\
\text { success. To maintain good citizenship as a company. " }\end{array}$ & 1 \\
\hline MMM & $3 \mathrm{M} \mathrm{CO}$ & $\begin{array}{l}\text { 3M is committed to actively contributing to sustainable development through } \\
\text { environmental protection, social responsibility and economic progress." }\end{array}$ & 1 \\
\hline $\mathrm{MO}$ & $\begin{array}{l}\text { ALTRIA GROUP } \\
\text { INC }\end{array}$ & $\begin{array}{l}\text { "Our Mission is to own and develop financially disciplined businesses that are } \\
\text { leaders in responsibly providing adult tobacco consumers with superior } \\
\text { branded products }\end{array}$ & 0 \\
\hline MRK & MERCK \& CO & $\begin{array}{c}\text { The mission of Merck is to provide society with superior products and services } \\
\text { by developing innovations and solutions that improve the quality of life } \\
\text { and satisfy customer needs, and to provide employees with meaningful } \\
\text { work and advancement opportunities, and investors with a superior rate of } \\
\text { return }\end{array}$ & 0 \\
\hline MRO & $\begin{array}{l}\text { MARATHON } \\
\text { OIL CORP }\end{array}$ & $\begin{array}{l}\text { Marathon is a company that strives to bring value and values together. We } \\
\text { create value for our shareholders and provide quality products and services } \\
\text { for our customers. In doing so, we act responsibly toward those who work } \\
\text { for us, the communities in which we operate and our business partners }\end{array}$ & 1 \\
\hline
\end{tabular}




\begin{tabular}{|c|c|c|c|c|}
\hline MSI & $\begin{array}{l}\text { MOTOROLA } \\
\text { SOLUTIONS } \\
\quad \text { INC }\end{array}$ & $\begin{array}{c}\text { We are a global communications leader powered by a passion to invent and an } \\
\text { unceasing commitment to advance the way the world connects. Our } \\
\text { communication solutions allow people, businesses and governments to be } \\
\text { more connected and more mobile }\end{array}$ & $\begin{array}{c}\text { Pur history is rich. Our } \\
\text { future is dynamic. } \\
\text { We are Motorola } \\
\text { and the spirit of } \\
\text { invention is what } \\
\text { drives us }\end{array}$ & 0 \\
\hline MU & $\begin{array}{l}\text { MICRON } \\
\text { TECHNOLOGY } \\
\text { INC }\end{array}$ & $\begin{array}{c}\text { Be the most efficient and innovative global provider of semiconductor } \\
\text { solutions }\end{array}$ & & 0 \\
\hline MWV & $\begin{array}{l}\text { MEADWESTVA } \\
\text { CO CORP }\end{array}$ & $\begin{array}{c}\text { From research and design to manufacturing and distribution capabilities, our } \\
\text { customers count on us to help them win in the global marketplace. We are } \\
\text { delivering new consumer experiences, enhancing our customers' abilities to } \\
\text { compete and grow profitably, and helping them perform more cost- } \\
\text { effectively around the world." }\end{array}$ & $\begin{array}{c}\text { ur global reach, market } \\
\text { and consumer } \\
\text { insights, } \\
\text { creativity, } \\
\text { materials, primary } \\
\text { and secondary } \\
\text { packaging, } \\
\text { systems and } \\
\text { support enhance } \\
\text { our ability to } \\
\text { create new } \\
\text { opportunities for } \\
\text { our employees } \\
\text { and generate } \\
\text { stronger returns to } \\
\text { our shareholders }\end{array}$ & 0 \\
\hline NCR & NCR CORP & $\begin{array}{l}\text { We are the new NCR: Leading how the world connects, interacts and } \\
\text { transacts with business. } \\
\text { Our people offer a broad perspective that enables our customers to reach } \\
\text { their goals and transform their business models. Our size, scale and } \\
\text { stability instil confidence in the marketplace }\end{array}$ & & 0 \\
\hline NKE & NIKE INC & To Bring Inspiration and innovation to every athlete in the world." & & 0 \\
\hline
\end{tabular}




\begin{tabular}{|c|c|c|c|}
\hline NOC & $\begin{array}{l}\text { NORTHROP } \\
\text { GRUMMAN } \\
\text { CORP }\end{array}$ & $\begin{array}{c}\text { Our vision is to be the most trusted provider of systems and technologies that } \\
\text { ensure the security and freedom of our nation and its allies. As the } \\
\text { technology leader, we will define the future of defense - from undersea to } \\
\text { outer space, and in cyberspace. We will - Conduct ourselves with } \\
\text { integrity and live our Company Values - Deliver superior program } \\
\text { performance- Foster an internal environment of innovation, } \\
\text { collaboration, and trust In so doing, Northrop Grumman will become our } \\
\text { customers' partner of choice, } \\
\text { our industry's employer of choice, and our shareholders' investment of } \\
\text { choice }\end{array}$ & 0 \\
\hline NOV & $\begin{array}{c}\text { NATIONAL } \\
\text { OILWELL } \\
\text { VARCO INC }\end{array}$ & $\begin{array}{l}\text { Integrity: We say what we mean, our actions reflect our words, and we honor } \\
\text { our commitments. } \\
\text { Customer Focus: Our customers are our number one priority and we } \\
\text { consistently meet or exceed their expectations. Enthusiasm: We are } \\
\text { passionate about our work and take pride in designing quality into the } \\
\text { products, services and solutions that we provide. Stakeholder Value } \\
\text { Creation: We employ creativity and initiative in the creation of } \\
\text { stakeholder value and are recognized and rewarded for it. Performance } \\
\text { Drives Results: We create our future through our choices and actions } \\
\text { today. Teamwork: We collaborate with our suppliers, our customers and } \\
\text { each other to optimize the sum of all individual efforts. Citizenship: We } \\
\text { honor the culture and laws of all areas in which we participate and } \\
\text { demonstrate respect for all." Through our company-wide product } \\
\text { development program, it is the goal of National Oilwell Varco to ensure } \\
\text { that our customers benefit from solutions that are continuously evolving } \\
\text { and improving. }\end{array}$ & 1 \\
\hline
\end{tabular}




\begin{tabular}{|c|c|c|c|}
\hline NUE & NUCOR CORP & $\begin{array}{l}\text { Nucor Corporation is made up of approximately } 20,000 \text { teammates whose } \\
\text { goal is to "Take Care of Our Customers." We are accomplishing this by } \\
\text { being the safest, highest quality, lowest cost, most productive and most } \\
\text { profitable steel and steel products company in the world. We are } \\
\text { committed to doing this while being cultural and environmental stewards } \\
\text { in our communities where we live and work. We are succeeding by } \\
\text { working together }\end{array}$ & 1 \\
\hline NWL & $\begin{array}{c}\text { NEWELL } \\
\text { RUBBERMAID } \\
\text { INC }\end{array}$ & $\begin{array}{l}\text { Our vision is to be a global company of Brands That Matter }{ }^{\mathrm{TM}} \text { and great } \\
\text { people, known for best-in-class results }\end{array}$ & 0 \\
\hline $\mathrm{OC}$ & DWENS CORNING & $\begin{array}{c}\text { Owens Corning is a company with an unwavering commitment to delivering } \\
\text { solutions, transforming markets and enhancing lives. It's who we are. It's } \\
\text { why we are here. We do it by fully engaging our employees in support of } \\
\text { growing our customer's businesses. And when we do, we grow ours as } \\
\text { well }\end{array}$ & 0 \\
\hline $\mathrm{OI}$ & $\begin{array}{l}\text { PWENS-ILLINOIS } \\
\text { INC }\end{array}$ & $\begin{array}{l}\text { Our mission is to design, manufacture, and deliver products and services that } \\
\text { meet the unique needs and expectations of each customer. To that end, we } \\
\text { have successfully built a solid foundation and infrastructure for glass } \\
\text { container manufacturing }\end{array}$ & 0 \\
\hline OSK & OSHKOSH CORP & $\begin{array}{c}\text { Oshkosh Corporation designs and builds the world's toughest specialty trucks } \\
\text { and truck bodies and access equipment by working shoulder-to-shoulder } \\
\text { with the people who use them. } \\
\text { We make it our business to understand the rigors of our customers' jobs, } \\
\text { and deliver vehicles to them that out-perform anything else on the market. } \\
\text { We then back those vehicles with a } 24 / 7 \text { global service network. And } \\
\text { because our company is broadly diversified, we can leverage our } \\
\text { proprietary technologies to create powerful competitive advantages } \\
\text { across many different ma }\end{array}$ & 0 \\
\hline
\end{tabular}




\begin{tabular}{|c|c|c|c|c|}
\hline PBI & TNEY BOWES INC & $\begin{array}{l}\text { We believe innovation and growth go hand-in-hand with long-held ideals } \\
\text { such as collaboration, integrity and accountability to deliver value for our } \\
\text { customers. } \\
\text { At Pitney Bowes, everything we do has one goal-to help our customers } \\
\text { achieve their goals. And today, more than two million companies are } \\
\text { improving their bottom-line results by connecting with their customers in } \\
\text { more meaningful ways }\end{array}$ & & 0 \\
\hline PCAR & PACCAR INC & $\begin{array}{l}\text { PACCAR is a global technology leader in the design, manufacture and } \\
\text { customer support of high-quality light-, medium and heavy-duty trucks } \\
\text { under the Kenworth, Peterbilt and DAF nameplates. It also provides } \\
\text { financial services and information technology and distributes truck parts } \\
\text { related to its principal business }\end{array}$ & & 0 \\
\hline PEP & PEPSICO INC & $\begin{array}{l}\text { To be the world's premier consumer products company focused on } \\
\text { convenient foods and beverages. We seek to produce healthy financial } \\
\text { rewards to investors as we provide opportunities for growth and } \\
\text { enrichment to our employees, our business partners and the communities } \\
\text { in which we operate. And in everything we do, we strive for honesty, } \\
\text { fairness and integrity }\end{array}$ & & 1 \\
\hline PFE & PFIZER INC & $\begin{array}{l}\text { We will become the world's most valued company to patients, customers, } \\
\text { colleagues, investors, business partners, and the communities where we } \\
\text { work and live." }\end{array}$ & $\begin{array}{c}t \text { Pfizer, we're inspired } \\
\text { by a single goal: } \\
\text { your health. That's } \\
\text { why we're } \\
\text { dedicated to } \\
\text { developing new, } \\
\text { safe medicines to } \\
\text { prevent and treat } \\
\text { the world's most } \\
\text { serious diseases. } \\
\text { And why we are } \\
\text { making them } \\
\text { available to the } \\
\text { people who need } \\
\text { them most. We } \\
\text { believe that from } \\
\text { progress comes }\end{array}$ & 1 \\
\hline
\end{tabular}




\begin{tabular}{|c|c|c|c|c|}
\hline & & & $\begin{array}{l}\text { hope and the } \\
\text { promise of a } \\
\text { healthier world }\end{array}$ & \\
\hline $\mathrm{PG}$ & $\begin{array}{l}\text { PROCTER \& } \\
\text { GAMBLE CO }\end{array}$ & $\begin{array}{c}\text { We will provide branded products and services of superior quality and value } \\
\text { that improve the lives of the world's consumers. As a result, consumers } \\
\text { will reward us with leadership sales, profit, and value creation, allowing } \\
\text { our people, our shareholders, and the communities in which we live and } \\
\text { work to prosper." }\end{array}$ & & 1 \\
\hline $\mathrm{PH}$ & $\begin{array}{l}\text { ARKER-HANNIFIN } \\
\text { CORP }\end{array}$ & $\begin{array}{c}\text { Parker Hannifin Corporation is the world's leading diversified manufacturer } \\
\text { of motion and control technologies, providing systematic, precision- } \\
\text { engineered solutions for a wide variety of commercial, mobile, industrial } \\
\text { and aerospace markets. " }\end{array}$ & & 0 \\
\hline PPG & $\begin{array}{c}\text { PPG INDUSTRIES } \\
\text { INC }\end{array}$ & $\begin{array}{c}\text { "PPG Industries is a leader in its markets; is a streamlined, efficient } \\
\text { manufacturer; and operates on the leading edge of new technologies and } \\
\text { solutions." }\end{array}$ & $\begin{array}{l}\text { It is our vision to } \\
\text { continue being the } \\
\text { world's leading } \\
\text { coatings and } \\
\text { specialty products } \\
\text { and services } \\
\text { company, serving } \\
\text { customers in } \\
\text { construction, } \\
\text { consumer } \\
\text { products, } \\
\text { industrial and } \\
\text { transportation } \\
\text { markets and } \\
\text { aftermarkets. " }\end{array}$ & 0 \\
\hline
\end{tabular}




\begin{tabular}{|c|c|c|c|c|}
\hline PX & PRAXAIR INC & $\begin{array}{l}\text { To be the best performing industrial gases company in the world as } \\
\text { determined by our customers, employees, shareholders, suppliers and the } \\
\text { communities in which we operate. " }\end{array}$ & & 1 \\
\hline QCOM & QUALCOMM INC & $\begin{array}{c}\text { Future Outlook From the lofty heights of dreams, we can see the future.Each } \\
\text { day, your vision of what tomorrow might hold inspires us. Each day, we } \\
\text { work to bring that vision to life as we lay the foundation for a new world } \\
\text { of wireless communication. So while no one can be absolutely certain } \\
\text { what tomorrow will bring, we have a pretty good idea. After all, with } \\
\text { your help, we're building it }\end{array}$ & & 0 \\
\hline RAI & $\begin{array}{l}\text { REYNOLDS } \\
\text { AMERICAN INC }\end{array}$ & $\begin{array}{c}\text { Reynolds American's mission is to be the innovative tobacco company } \\
\text { totally committed to building value } \\
\text { through responsible growth }\end{array}$ & & 1 \\
\hline ROK & $\begin{array}{l}\text { ROCKWELL } \\
\text { AUTOMATION }\end{array}$ & $\begin{array}{l}\text { Be the Most Valued Global Provider of Power, Control, \&Information } \\
\text { Solutions. Our strategic SMART (Specific,Measurable, Attainable, } \\
\text { Results-oriented, Time bound) goal-setting process links our quality } \\
\text { performance objectives across every level of the organization }\end{array}$ & & 0 \\
\hline RRD & $\begin{array}{l}\text { ONNELLEY (R R) } \\
\text { \& SONS CO }\end{array}$ & $\begin{array}{l}\text { Customer satisfaction will be the paramount consideration in the } \\
\text { performance of every aspect of our work," } \\
\text { "each of us must act with integrity and adhere to the highest standards of } \\
\text { business ethics }\end{array}$ & & 1 \\
\hline RTN & RAYTHEON CO & $\begin{array}{l}\text { Our people and products are currently providing solutions across the LVC } \\
\text { and C2 domains, saving lives and saving money for the warfighter." }\end{array}$ & & 0 \\
\hline SEE & EALED AIR CORP & $\begin{array}{l}\text { Whether we're creating new markets or expanding into new geographies, } \\
\text { reducing the amount of packaging our customers use, eliminating waste } \\
\text { in our own facilities, or just doing what we've always said - meeting the } \\
\text { packaging needs of customers and consumers around the world - we are }\end{array}$ & $\begin{array}{l}\text { Sealed Air will be the } \\
\text { global supplier of } \\
\text { choice for } \\
\text { solutions, }\end{array}$ & 1 \\
\hline
\end{tabular}




\begin{tabular}{|c|c|c|c|c|}
\hline & & $\begin{array}{c}\text { continuously raising the bar on performance knowing that good } \\
\text { packaging saves food, time, energy and valuable resources }\end{array}$ & $\begin{array}{c}\text { products and } \\
\text { services that } \\
\text { improve our } \\
\text { customer's } \\
\text { bottom-line in the } \\
\text { markets we serve }\end{array}$ & \\
\hline SFD & $\begin{array}{l}\text { SMITHFIELD } \\
\text { FOODS INC }\end{array}$ & $\begin{array}{l}\text { To be a trusted, respected and ethical food industry leader that excels at } \\
\text { bringing delicious and nutritious meat and specialty food products to } \\
\text { millions every day while setting industry standards for corporate social } \\
\text { responsibility }\end{array}$ & & 1 \\
\hline SHW & $\begin{array}{l}\text { SHERWIN- } \\
\text { WILLIAMS CO }\end{array}$ & $\begin{array}{c}\text { For over } 140 \text { years, manufacturers have trusted Sherwin-Williams for } \\
\text { innovative coatings and exceptional service. And you can count on us for } \\
\text { the expertise and the support you need to get better results, from start to } \\
\text { finish. " }\end{array}$ & & 0 \\
\hline SLE & SARA LEE CORP & $\begin{array}{l}\text { Sara Lee's mission is to feed, clothe and care for consumers and their } \\
\text { families the world over." }\end{array}$ & & 0 \\
\hline SPW & SPX CORP & $\begin{array}{l}\text { From power generation to food processing, SPX solutions are helping to } \\
\text { meet the needs of a growing, ever-changing world. We don't just talk } \\
\text { about ideas. We make them happen - in our customers' manufacturing } \\
\text { plants, on their construction sites, in their laboratories, underground and } \\
\text { even in cyberspace. } \\
\text { Whether producing innovative process equipment and diagnostic tools or } \\
\text { helping to develop global infrastructure, SPX is transforming ideas into } \\
\text { powerful solutions." }\end{array}$ & & 0 \\
\hline
\end{tabular}




\begin{tabular}{|c|c|c|c|}
\hline SUN & SUNOCO INC & $\begin{array}{c}\text { Our Purpose is to: } \\
\text { Be a source of excellence for our customers; } \\
\text { Provide a challenging professional experience for our employees; } \\
\text { Be a rewarding investment for our shareholders; } \\
\text { Be a respected citizen of community and country." }\end{array}$ & 1 \\
\hline SYK & STRYKER CORP & $\begin{array}{c}\text { Stryker Corporation is a broadly based, global leader in medical technology } \\
\text { that consistently delivers exceptional results. Stryker works with } \\
\text { respected medical professionals to advance meaningful innovation, } \\
\text { reduce health-care costs and improve people's lives." }\end{array}$ & 0 \\
\hline TAP & $\begin{array}{l}\text { MOLSON COORS } \\
\text { BREWING CO }\end{array}$ & $\begin{array}{l}\text { Molson Coors' vision is to be a top-performing brewer winning through } \\
\text { inspired employees and great brands. We're driving growth by becoming } \\
\text { an innovative, brand-led company, delivering and re-investing } \\
\text { productivity for growth as we build a winning, value-based culture }\end{array}$ & 0 \\
\hline
\end{tabular}




\begin{tabular}{|c|c|c|c|c|}
\hline TEX & TEREX CORP & $\begin{array}{c}\text { To delight our current and future construction, infrastructure, mining, and } \\
\text { other customers with value added offerings that exceed their current and } \\
\text { future needs. } \\
\text { To achieve our mission we must attract the best people by creating a } \\
\text { Terex culture that is } \\
\text { safe, exciting, creative, fun and embraces continuous improvement }\end{array}$ & $\begin{array}{c}\text { Customer - to be the } \\
\text { most customer } \\
\text { responsive } \\
\text { company in the } \\
\text { industry as } \\
\text { determined by our } \\
\text { customers } \\
\\
\text { Financial - to be } \\
\text { the most } \\
\text { profitable } \\
\text { company in the } \\
\text { industry as } \\
\text { measured by } \\
\text { ROIC } \\
\\
\text { Team Member - } \\
\text { to be the best } \\
\text { place to work in } \\
\text { the industry as } \\
\text { determined by our } \\
\text { team members }\end{array}$ & 0 \\
\hline TKR & TIMKEN CO & $\begin{array}{l}\text { We are dedicated to improving our customers' performance } \\
\text { by applying our knowledge of friction management and power } \\
\text { transmission } \\
\text { to deliver unparalleled value and innovation all around the world. }\end{array}$ & & 0 \\
\hline TMO & $\begin{array}{l}\text { THERMO FISHER } \\
\text { SCIENTIFIC INC }\end{array}$ & $\begin{array}{l}\text { Serving customers through two premier brands, Thermo Scientific and Fisher } \\
\text { Scientific, we help solve analytical challenges from routine testing to } \\
\text { complex research and discovery }\end{array}$ & & 0 \\
\hline TRW & $\begin{array}{l}\text { RW AUTOMOTIVE } \\
\text { HOLDINGS } \\
\text { CORP }\end{array}$ & To be the Global Leader in Automotive Safety Systems." & & 0 \\
\hline
\end{tabular}




\begin{tabular}{|c|c|c|c|c|}
\hline TSN & $\begin{array}{c}\text { YSON FOODS INC } \\
\text {-CL A }\end{array}$ & $\begin{array}{c}\text { We are dedicated to producing and marketing trusted quality food products } \\
\text { that fit today's changing lifestyles and to attracting, rewarding and } \\
\text { retaining the best people in the food industry." }\end{array}$ & $\begin{array}{c}\text { ur vision at Tyson is to } \\
\text { be the world's } \\
\text { first choice for } \\
\text { protein while } \\
\text { maximizing } \\
\text { shareholder value }\end{array}$ & 0 \\
\hline $\mathrm{TSO}$ & TESORO CORP & $\begin{array}{l}\text { At Tesoro, we value the relationships we develop with our customers, the } \\
\text { performance we deliver for our shareholders and the responsibility we } \\
\text { hold for our communities." }\end{array}$ & & 1 \\
\hline TXN & $\begin{array}{l}\text { TEXAS } \\
\text { INSTRUMENTS } \\
\quad \text { INC }\end{array}$ & $\begin{array}{l}\text { Texas Instruments develops analog, digital signal processing, RF and DLP® } \\
\text { semiconductor technologies that help customers deliver consumer and } \\
\text { industrial electronics products with greater performance, increased power } \\
\text { efficiency, higher precision, more mobility and better quality }\end{array}$ & & 0 \\
\hline TXT & TEXTRON INC & $\begin{array}{l}\text { Textron's vision is to become the premier multi-industry company, } \\
\text { recognized for our network of powerful brands, world-class enterprise } \\
\text { processes and talented people }\end{array}$ & & 0 \\
\hline UTX & $\begin{array}{l}\text { UNITED } \\
\text { TECHNOLOGIES } \\
\text { CORP }\end{array}$ & $\begin{array}{l}\text { UTC is committed to continuous improvement. We operate an extensive } \\
\text { research program to identify innovations and technologies to enable us to } \\
\text { relentlessly improve the quality of our product." }\end{array}$ & & 0 \\
\hline VFC & VF CORP & $\begin{array}{l}\text { We will grow by building leading lifestyle brands that excite consumers } \\
\text { around the world. } \\
\text { Ours is a perpetually driven culture, focused on constant innovation. } \\
\text { Using deep research and insights, we combine the art and science of } \\
\text { apparel to create products that excite consumers and brands that inspire } \\
\text { loyalty. } \\
\text { We responsibly manage the industry's most efficient and complex supply } \\
\text { chain, which spans multiple geographies, product categories and } \\
\text { distribution channels. }\end{array}$ & & 0 \\
\hline
\end{tabular}




\begin{tabular}{|c|c|c|c|}
\hline & & $\begin{array}{l}\text { Our goal is to continuously exceed the expectations of our consumers, } \\
\text { customers, shareholders and business partners. We help our retail partners } \\
\text { win with consistently solid execution and outstanding service. And we } \\
\text { continually find ways to improve our performance and generate bottom } \\
\text { line results. }\end{array}$ & \\
\hline VLO & $\begin{array}{c}\text { IALERO ENERGY } \\
\text { CORP }\end{array}$ & $\begin{array}{c}\text { As a leading refiner and marketer, we are committed to following these } \\
\text { guiding principles to achieve excellence in our business, our industry, and } \\
\text { our relationships with our employees and communities. } \\
\text { Commitment to Safety } \\
\text { highest priority. } \\
\text { Commitment to Our Stakeholders } \\
\text { We are committed to delivering long-term value to all stakeholders - our } \\
\text { employees, investors, and customers - by pursuing profitable, value- } \\
\text { enhancing strategies with a focus on world-class operations. } \\
\text { Commitment to Our Employees } \\
\text { Our employees are our No. } 1 \text { asset. We are committed to providing a } \\
\text { challenging, enjoyable and rewarding work environment, which fosters } \\
\text { creative thinking, teamwork, open communication, respect and } \\
\text { opportunity for individual professional growth and development. } \\
\text { Commitment to the Environment } \\
\text { We are committed to producing environmentally clean products, while } \\
\text { striving to improve and enhance the environmental quality of our } \\
\text { operations within our local communities. } \\
\text { Commitment to our Communities } \\
\text { We are committed to taking a leadership role in the communities in which } \\
\text { we live and work by providing company support and encouraging } \\
\text { employee involvement }\end{array}$ & 1 \\
\hline WDC & $\begin{array}{c}\text { ESTERN DIGITAL } \\
\text { CORP }\end{array}$ & $\begin{array}{l}\text { Designing, manufacturing and selling hard drives is all that we do. We } \\
\text { understand the importance of the data you put on your hard drives. We } \\
\text { focus our passion, knowledge and innovation on products that reliably } \\
\text { keep your information and } \\
\text { content safe and close at hand }\end{array}$ & 0 \\
\hline
\end{tabular}




\begin{tabular}{|c|c|c|c|c|}
\hline WHR & VHIRLPOOL CORP & $\begin{array}{l}\text { Every Home... Everywhere... with Pride, Passion and Performance } \\
\text { Our vision reinforces that every home is our domain, every customer and } \\
\text { customer activity our opportunity. This vision fuels the passion that we } \\
\text { have for our customers, pushing us to provide innovative solutions to } \\
\text { uniquely meet their needs. } \\
\text { Pride... in our work and each other } \\
\text { Passion... for creating unmatched customer loyalty for our brands } \\
\text { Performance... that excites and rewards global investors with superior } \\
\text { returns } \\
\text { We bring this vision to life through the power of our unique global } \\
\text { enterprise and } \\
\text { our outstanding people... working together... everywhere }\end{array}$ & & 0 \\
\hline WY & $\begin{array}{c}\text { NEYERHAEUSER } \\
\text { CO }\end{array}$ & $\begin{array}{c}\text { For more than a century, Weyerhaeuser has released the potential in trees to } \\
\text { solve important problems for people and the planet. } \\
\text { The need for such imaginative, sustainable solutions to the world's } \\
\text { challenges has never been greater. As an international forest products } \\
\text { company, Weyerhaeuser is uniquely qualified to meet these needs and } \\
\text { those of our customers } \\
\text { in ways that create ongoing prosperity." }\end{array}$ & & 1 \\
\hline $\mathrm{X}$ & $\begin{array}{c}\text { UNITED STATES } \\
\text { STEEL CORP }\end{array}$ & $\begin{array}{c}\text { At U. S. Steel, creating value for our stakeholders is a priority. To ensure our } \\
\text { long-term success, we aim to build value for our customers, employees, } \\
\text { shareholders, creditors, and the communities in which we operate using } \\
\text { the same responsible approach that has positioned us as a leader in our } \\
\text { industry. }\end{array}$ & $\begin{array}{c}\text { ompanies that want to } \\
\text { be competitive in } \\
\text { an increasingly } \\
\text { global } \\
\text { marketplace must } \\
\text { have a global } \\
\text { outlook and } \\
\text { presence. U. S. } \\
\text { Steel continually }\end{array}$ & 1 \\
\hline
\end{tabular}




\begin{tabular}{|c|c|c|c|c|}
\hline & & & $\begin{array}{c}\text { looks for } \\
\text { opportunities to } \\
\text { strengthen our } \\
\text { existing presence } \\
\text { in the global arena } \\
\text { and strives to } \\
\text { meet and set } \\
\text { world-class } \\
\text { standards in } \\
\text { everything we do. } \\
\text { " }\end{array}$ & \\
\hline XOM & $\begin{array}{c}\text { EXXON MOBIL } \\
\text { CORP }\end{array}$ & $\begin{array}{l}\text { Exxon Mobil Corporation is committed to being the world's premier } \\
\text { petroleum and petrochemical company. To that end, we must } \\
\text { continuously achieve superior financial and operating results while } \\
\text { adhering to the highest standards of business conduct. These unwavering } \\
\text { expectations provide the foundation for our commitments to those with } \\
\text { whom we interact." }\end{array}$ & & 1 \\
\hline XRX & XEROX CORP & $\begin{array}{c}\text { Our strategic intent is to help people find better ways to do great work -- by } \\
\text { constantly leading in document technologies, } \\
\text { products and services that improve our customers' work processes and } \\
\text { business results }\end{array}$ & & 0 \\
\hline
\end{tabular}


Appendix 3 - Comparison of Management Standards Variable and GEP 
Appendix 3: Comparison of Management Standards Variable and GEP

The below comparison is based on data provided in the methodology report issued by the providers of these databases found at http://www.thedailybeast.com/newsweek/2011/10/16/newsweek-green-rankings-2011-full-methodology.html

\begin{tabular}{|c|c|c|}
\hline & $\begin{array}{c}\text { Management Standards (Green Policy } \\
\text { Score) }\end{array}$ & $\begin{array}{l}\text { Global Environmental Performance (Green impact } \\
\qquad \text { Score) }\end{array}$ \\
\hline $\begin{array}{l}\text { Provider of } \\
\text { Data }\end{array}$ & $\begin{array}{l}\text { Provided by MSCI ESG (environmental, } \\
\text { social and governance )Research, } \\
\text { same people that provide KLD data over } \\
\text { the past } 20 \text { years, except now they are } \\
\text { called MSCI ESG. } \\
\text { MSCIESG Research: } \\
\text { ESGclientservice@msci.com }\end{array}$ & $\begin{array}{l}\text { Provided by Trucost, who is the world's most } \\
\text { comprehensive data provider on corporate environmental } \\
\text { impacts for the last } 10 \text { years. } \\
\text { Trucost: greenrankings@trucost.com }\end{array}$ \\
\hline $\begin{array}{l}\text { Variable } \\
\text { description } \\
\text { by its } \\
\text { providers }\end{array}$ & $\begin{array}{l}\text { "Assessment of how a company } \\
\text { manages its environmental footprint. } \\
\text { The MSCI ESG Research scoring model } \\
\text { measures the quality of each company's } \\
\text { environmental reporting, policies, } \\
\text { programs, and initiatives" }\end{array}$ & $\begin{array}{l}\text { A score is an assessment of the company's actual } \\
\text { environmental footprint of its global operations (Green } \\
\text { impact Score) }\end{array}$ \\
\hline $\begin{array}{l}\text { Number of } \\
\text { items } \\
\text { covered }\end{array}$ & $\begin{array}{l}\text { More than } 70 \text { individual indicators are } \\
\text { incorporated into the Green Policies } \\
\text { Score. }\end{array}$ & $\begin{array}{l}\text { This data is a comprehensive, quantitative, and } \\
\text { standardized measurement made up of more than } 700 \\
\text { metrics to assess the total environmental impacts of a } \\
\text { corporation's global operations ( } 90 \text { percent) and }\end{array}$ \\
\hline
\end{tabular}




\begin{tabular}{|c|c|c|}
\hline & & disclosure of those impacts (10 percent). \\
\hline $\begin{array}{l}\text { Information } \\
\text { Areas } \\
\text { covered }\end{array}$ & $\begin{array}{l}\text { Categorized into the following issues: } \\
\text { Climate-change policies and } \\
\text { performance: how well each } \\
\text { company manages its carbon } \\
\text { emissions; } \\
\text { - Pollution policies and } \\
\text { performance: how well each } \\
\text { company manages its noncarbon } \\
\text { emissions to air, water, and land; } \\
\text { Product impact: the life-cycle } \\
\text { impacts of each company's } \\
\text { products and services; } \\
\text { Environmental stewardship: how } \\
\text { well each company manages and } \\
\text { uses its local resources; } \\
\text { Management of environmental } \\
\text { issues: the quality of each } \\
\text { company's track record of } \\
\text { managing environmental risks. } \\
\text { Reporting Quality: Does the } \\
\text { company report on goal } \\
\text { setting?/Does the company } \\
\text { report publish a CSR Report? } \\
\text { What are the CSR topics covered } \\
\text { by the report? Is the report } \\
\text { externally verified? Does the } \\
\text { company report qualitative or }\end{array}$ & $\begin{array}{l}\text { The emissions of nine key greenhouse gases, water use, } \\
\text { solid-waste disposal, and emissions that contribute to } \\
\text { acid rain and smog }\end{array}$ \\
\hline
\end{tabular}




\begin{tabular}{|c|c|c|}
\hline & quantitative data in the report? & \\
\hline Data Sources & $\begin{array}{l}\text { MSCI ESG Research draws its data } \\
\text { from a variety of sources, including } \\
\text { company-disclosed information; } \\
\text { dialogues with companies; media } \\
\text { coverage; and government, NGO, and } \\
\text { third-party research. }\end{array}$ & $\begin{array}{l}\text { "Trucost uses publicly disclosed environmental data to } \\
\text { evaluate company performance for each impact metric } \\
\text { whenever possible." } \\
\text { "Trucost draws on any relevant data that's available, } \\
\text { such as the EPA Toxics Release Inventory, to further } \\
\text { refine the model. Any outside data that Trucost draws in } \\
\text { is first scrutinized to ensure it is of good quality, and then } \\
\text { standardized before being used." }\end{array}$ \\
\hline $\begin{array}{l}\text { How it is } \\
\text { Calculated }\end{array}$ & $\begin{array}{l}\text { "The initial data is used to rate } \\
\text { companies on a scale of zero to } 100 \text { for } \\
\text { specific indicators, and then those } \\
\text { factors, weighted according to their } \\
\text { importance, are rolled up into scores for } \\
\text { each of the five key environmental } \\
\text { issues, and then into the overall raw } \\
\text { GPS" }\end{array}$ & $\begin{array}{l}\text { "Uses a proprietary economic input-output model to } \\
\text { calculate direct-company and supply-chain impacts in } \\
\text { cases where data is unavailable. To fairly assess the } \\
\text { impacts of companies operating in more than one } \\
\text { industry, Trucost uses a benchmarking system. First, } \\
\text { Trucost calculates the total environmental impacts per } \\
\text { total economic output (usually in dollars of revenue) for } \\
464 \text { industry sectors. Then, it evaluates the proportion of } \\
\text { a company's revenue that is derived from each sector in } \\
\text { which it does business. This research is fed into the } \\
\text { model, which uses the benchmarks for each of those } \\
\text { sectors (for example, total water use of the oil industry } \\
\text { per its total economic output) to estimate the company's } \\
\text { impacts (in this case, its water use)." } \\
\text { "Once the specific impacts of a company have been } \\
\text { quantitatively assessed, Trucost calculates an } \\
\text { environmental damage cost for each-a dollar value }\end{array}$ \\
\hline
\end{tabular}




\begin{tabular}{|c|c|}
\hline & $\begin{array}{l}\text { representing the potential cost to society of resulting } \\
\text { damage to the environment_based on a standardized } \\
\text { cost per quantity of each environmental input or output } \\
\text { that Trucost has developed from valuation studies and } \\
\text { other academic literature. The costs for each individual } \\
\text { metric are added up to produce a dollar estimate of the } \\
\text { company's total environmental impact. Finally, this } \\
\text { figure is normalized by company fiscal-year revenue } \\
\text { (this allows companies of all sizes to be compared) and } \\
\text { factored in as } 90 \text { percent of the company's raw EIS." } \\
\text { "Trucost's disclosure score credits companies for } \\
\text { releasing usable data that cover its global operations for } \\
\text { each of the individual environmental-impact metrics that } \\
\text { Trucost tracks, weighted according to the relative } \\
\text { importance of each impact to the company's overall } \\
\text { footprint. For example, if Trucost determines that a given } \\
\text { company's footprint is comprised of } 50 \text { percent } \\
\text { greenhouse gas emissions, } 25 \text { percent dust and particle } \\
\text { emissions, and } 25 \text { percent water use, but that only the } \\
\text { first two factors were disclosed comprehensively, then } \\
\text { the company would get a disclosure score of } 75 \text { percent. } \\
\text { This score factors in as } 10 \text { percent of the company's raw } \\
\text { EIS." }\end{array}$ \\
\hline \multicolumn{2}{|c|}{$\begin{array}{l}\text { The below lists the items removed from the Environmental Management (GPS) Variable for potential overlap with } \\
\text { GEP measure }\end{array}$} \\
\hline \multicolumn{2}{|l|}{$\begin{array}{l}\text { Key Data: Direct GHG Emissions Data } \\
\text { Key Data: Indirect GHG Emissions Data } \\
\text { Key Data: Nitrogen Oxides (NOx) } \\
\text { Key Data: Sulfur Dioxide (SO2/SOx) }\end{array}$} \\
\hline
\end{tabular}




\begin{tabular}{|l|}
\hline Key Data: Particulate Matter \\
Key Data: Mercury \\
Key Data: VOC \\
Key Data: Toluene \\
Key Data: Hydrogen Sulfide \\
Key Data: Ozone Depleting Substances \\
Key Data: Lead \\
Key Data: Other Emissions to Air \\
Key Data: Releases to Water \\
Key Data: Non-Hazardous Solid Waste \\
Key Data: Hazardous Waste \\
Key Data: Other Releases to Land \\
Key Data: Toxic Release Inventory Data \\
Key data: Total Water Withdrawal \\
Key Data: Water Sourcing \\
\hline
\end{tabular}


Appendix 4: Hierarchical Clustering Agglomeration Schedule

Agglomeration Schedule

\begin{tabular}{|c|c|c|c|c|c|c|}
\hline \multirow[b]{2}{*}{ Stage } & \multicolumn{2}{|c|}{ Cluster Combined } & \multirow[b]{2}{*}{ Coefficients } & \multicolumn{2}{|c|}{$\begin{array}{c}\text { Stage Cluster First } \\
\text { Appears } \\
\end{array}$} & \multirow[b]{2}{*}{ Next Stage } \\
\hline & Cluster 1 & Cluster 2 & & Cluster 1 & Cluster 2 & \\
\hline 1 & 140 & 143 & .005 & 0 & 0 & 54 \\
\hline 2 & 52 & 106 & .029 & 0 & 0 & 4 \\
\hline 3 & 41 & 77 & .099 & 0 & 0 & 39 \\
\hline 4 & 52 & 145 & .171 & 2 & 0 & 39 \\
\hline 5 & 82 & 137 & .243 & 0 & 0 & 47 \\
\hline 6 & 60 & 89 & .318 & 0 & 0 & 86 \\
\hline 7 & 22 & 124 & .394 & 0 & 0 & 17 \\
\hline 8 & 62 & 152 & .487 & 0 & 0 & 78 \\
\hline 9 & 36 & 148 & .586 & 0 & 0 & 20 \\
\hline 10 & 4 & 99 & .686 & 0 & 0 & 105 \\
\hline 11 & 49 & 110 & .808 & 0 & 0 & 40 \\
\hline 12 & 7 & 109 & .936 & 0 & 0 & 75 \\
\hline 13 & 96 & 125 & 1.068 & 0 & 0 & 22 \\
\hline 14 & 26 & 126 & 1.201 & 0 & 0 & 50 \\
\hline 15 & 54 & 114 & 1.337 & 0 & 0 & 30 \\
\hline 16 & 111 & 141 & 1.489 & 0 & 0 & 122 \\
\hline 17 & 22 & 142 & 1.655 & 7 & 0 & 23 \\
\hline 18 & 3 & 46 & 1.826 & 0 & 0 & 110 \\
\hline 19 & 101 & 113 & 1.999 & 0 & 0 & 83 \\
\hline 20 & 36 & 139 & 2.176 & 9 & 0 & 91 \\
\hline 21 & 129 & 156 & 2.359 & 0 & 0 & 32 \\
\hline 22 & 87 & 96 & 2.543 & 0 & 13 & 71 \\
\hline 23 & 22 & 131 & 2.740 & 17 & 0 & 96 \\
\hline 24 & 10 & 86 & 2.936 & 0 & 0 & 67 \\
\hline 25 & 66 & 157 & 3.135 & 0 & 0 & 90 \\
\hline 26 & 71 & 88 & 3.345 & 0 & 0 & 58 \\
\hline 27 & 17 & 153 & 3.558 & 0 & 0 & 120 \\
\hline 28 & 59 & 118 & 3.782 & 0 & 0 & 60 \\
\hline 29 & 84 & 127 & 4.007 & 0 & 0 & 89 \\
\hline 30 & 54 & 67 & 4.233 & 15 & 0 & 53 \\
\hline 31 & 27 & 40 & 4.461 & 0 & 0 & 62 \\
\hline 32 & 105 & 129 & 4.693 & 0 & 21 & 63 \\
\hline 33 & 93 & 119 & 4.934 & 0 & 0 & 85 \\
\hline 34 & 12 & 42 & 5.182 & 0 & 0 & 89 \\
\hline 35 & 53 & 155 & 5.439 & 0 & 0 & 65 \\
\hline 36 & 24 & 90 & 5.698 & 0 & 0 & 92 \\
\hline
\end{tabular}




\begin{tabular}{|c|c|c|c|c|c|c|}
\hline 37 & 29 & 115 & 5.963 & 0 & 0 & 116 \\
\hline 38 & 2 & 39 & 6.233 & 0 & 0 & 102 \\
\hline 39 & 41 & 52 & 6.510 & 3 & 4 & 91 \\
\hline 40 & 49 & 133 & 6.790 & 11 & 0 & 55 \\
\hline 41 & 1 & 14 & 7.082 & 0 & 0 & 115 \\
\hline 42 & 38 & 68 & 7.383 & 0 & 0 & 123 \\
\hline 43 & 85 & 159 & 7.694 & 0 & 0 & 66 \\
\hline 44 & 134 & 136 & 8.005 & 0 & 0 & 104 \\
\hline 45 & 8 & 9 & 8.323 & 0 & 0 & 106 \\
\hline 46 & 6 & 103 & 8.644 & 0 & 0 & 62 \\
\hline 47 & 57 & 82 & 8.984 & 0 & 5 & 64 \\
\hline 48 & 20 & 95 & 9.327 & 0 & 0 & 80 \\
\hline 49 & 70 & 78 & 9.670 & 0 & 0 & 88 \\
\hline 50 & 26 & 116 & 10.018 & 14 & 0 & 51 \\
\hline 51 & 26 & 73 & 10.379 & 50 & 0 & 126 \\
\hline 52 & 102 & 151 & 10.749 & 0 & 0 & 106 \\
\hline 53 & 54 & 154 & 11.120 & 30 & 0 & 78 \\
\hline 54 & 140 & 147 & 11.509 & 1 & 0 & 103 \\
\hline 55 & 49 & 132 & 11.905 & 40 & 0 & 95 \\
\hline 56 & 34 & 43 & 12.305 & 0 & 0 & 73 \\
\hline 57 & 47 & 65 & 12.706 & 0 & 0 & 94 \\
\hline 58 & 71 & 138 & 13.115 & 26 & 0 & 125 \\
\hline 59 & 18 & 51 & 13.539 & 0 & 0 & 115 \\
\hline 60 & 56 & 59 & 13.969 & 0 & 28 & 103 \\
\hline 61 & 15 & 94 & 14.404 & 0 & 0 & 98 \\
\hline 62 & 6 & 27 & 14.847 & 46 & 31 & 86 \\
\hline 63 & 105 & 150 & 15.292 & 32 & 0 & 138 \\
\hline 64 & 28 & 57 & 15.764 & 0 & 47 & 116 \\
\hline 65 & 53 & 117 & 16.241 & 35 & 0 & 118 \\
\hline 66 & 85 & 149 & 16.731 & 43 & 0 & 69 \\
\hline 67 & 10 & 135 & 17.227 & 24 & 0 & 107 \\
\hline 68 & 76 & 108 & 17.728 & 0 & 0 & 95 \\
\hline 69 & 85 & 91 & 18.269 & 66 & 0 & 104 \\
\hline 70 & 19 & 160 & 18.810 & 0 & 0 & 117 \\
\hline 71 & 81 & 87 & 19.355 & 0 & 22 & 93 \\
\hline 72 & 21 & 58 & 19.907 & 0 & 0 & 119 \\
\hline 73 & 11 & 34 & 20.467 & 0 & 56 & 101 \\
\hline 74 & 30 & 44 & 21.038 & 0 & 0 & 97 \\
\hline 75 & 7 & 97 & 21.611 & 12 & 0 & 109 \\
\hline 76 & 23 & 144 & 22.198 & 0 & 0 & 138 \\
\hline 77 & 31 & 80 & 22.809 & 0 & 0 & 117 \\
\hline 78 & 54 & 62 & 23.429 & 53 & 8 & 100 \\
\hline
\end{tabular}




\begin{tabular}{|c|c|c|c|c|c|c|}
\hline 79 & 25 & 55 & 24.062 & 0 & 0 & 87 \\
\hline 80 & 20 & 72 & 24.722 & 48 & 0 & 130 \\
\hline 81 & 48 & 123 & 25.390 & 0 & 0 & 105 \\
\hline 82 & 16 & 35 & 26.061 & 0 & 0 & 131 \\
\hline 83 & 13 & 101 & 26.739 & 0 & 19 & 142 \\
\hline 84 & 83 & 121 & 27.424 & 0 & 0 & 128 \\
\hline 85 & 93 & 120 & 28.157 & 33 & 0 & 100 \\
\hline 86 & 6 & 60 & 28.926 & 62 & 6 & 127 \\
\hline 87 & 25 & 32 & 29.716 & 79 & 0 & 108 \\
\hline 88 & 70 & 128 & 30.521 & 49 & 0 & 124 \\
\hline 89 & 12 & 84 & 31.332 & 34 & 29 & 114 \\
\hline 90 & 66 & 162 & 32.163 & 25 & 0 & 121 \\
\hline 91 & 36 & 41 & 33.015 & 20 & 39 & 118 \\
\hline 92 & 24 & 158 & 33.915 & 36 & 0 & 112 \\
\hline 93 & 81 & 146 & 34.824 & 71 & 0 & 107 \\
\hline 94 & 33 & 47 & 35.745 & 0 & 57 & 133 \\
\hline 95 & 49 & 76 & 36.686 & 55 & 68 & 126 \\
\hline 96 & 22 & 92 & 37.634 & 23 & 0 & 112 \\
\hline 97 & 30 & 37 & 38.611 & 74 & 0 & 124 \\
\hline 98 & 15 & 79 & 39.655 & 61 & 0 & 111 \\
\hline 99 & 98 & 107 & 40.726 & 0 & 0 & 131 \\
\hline 100 & 54 & 93 & 41.801 & 78 & 85 & 119 \\
\hline 101 & 11 & 122 & 42.894 & 73 & 0 & 123 \\
\hline 102 & 2 & 75 & 44.049 & 38 & 0 & 141 \\
\hline 103 & 56 & 140 & 45.241 & 60 & 54 & 127 \\
\hline 104 & 85 & 134 & 46.435 & 69 & 44 & 136 \\
\hline 105 & 4 & 48 & 47.726 & 10 & 81 & 137 \\
\hline 106 & 8 & 102 & 49.020 & 45 & 52 & 113 \\
\hline 107 & 10 & 81 & 50.353 & 67 & 93 & 144 \\
\hline 108 & 25 & 130 & 51.702 & 87 & 0 & 132 \\
\hline 109 & 7 & 50 & 53.082 & 75 & 0 & 135 \\
\hline 110 & 3 & 100 & 54.472 & 18 & 0 & 129 \\
\hline 111 & 15 & 161 & 55.869 & 98 & 0 & 135 \\
\hline 112 & 22 & 24 & 57.322 & 96 & 92 & 146 \\
\hline 113 & 8 & 74 & 58.841 & 106 & 0 & 147 \\
\hline 114 & 12 & 61 & 60.411 & 89 & 0 & 128 \\
\hline 115 & 1 & 18 & 61.987 & 41 & 59 & 142 \\
\hline 116 & 28 & 29 & 63.619 & 64 & 37 & 125 \\
\hline 117 & 19 & 31 & 65.252 & 70 & 77 & 130 \\
\hline 118 & 36 & 53 & 66.979 & 91 & 65 & 143 \\
\hline 119 & 21 & 54 & 68.845 & 72 & 100 & 139 \\
\hline 120 & 17 & 45 & 70.855 & 27 & 0 & 148 \\
\hline
\end{tabular}




\begin{tabular}{|c|c|c|c|c|c|c|}
\hline 121 & 66 & 104 & 73.055 & 90 & 0 & 144 \\
\hline 122 & 64 & 111 & 75.295 & 0 & 16 & 129 \\
\hline 123 & 11 & 38 & 77.663 & 101 & 42 & 150 \\
\hline 124 & 30 & 70 & 80.037 & 97 & 88 & 134 \\
\hline 125 & 28 & 71 & 82.514 & 116 & 58 & 133 \\
\hline 126 & 26 & 49 & 85.037 & 51 & 95 & 143 \\
\hline 127 & 6 & 56 & 87.776 & 86 & 103 & 139 \\
\hline 128 & 12 & 83 & 90.604 & 114 & 84 & 137 \\
\hline 129 & 3 & 64 & 93.512 & 110 & 122 & 145 \\
\hline 130 & 19 & 20 & 96.540 & 117 & 80 & 141 \\
\hline 131 & 16 & 98 & 99.720 & 82 & 99 & 140 \\
\hline 132 & 5 & 25 & 102.928 & 0 & 108 & 145 \\
\hline 133 & 28 & 33 & 106.147 & 125 & 94 & 151 \\
\hline 134 & 30 & 63 & 109.478 & 124 & 0 & 147 \\
\hline 135 & 7 & 15 & 112.972 & 109 & 111 & 150 \\
\hline 136 & 69 & 85 & 116.525 & 0 & 104 & 149 \\
\hline 137 & 4 & 12 & 120.700 & 105 & 128 & 155 \\
\hline 138 & 23 & 105 & 125.090 & 76 & 63 & 153 \\
\hline 139 & 6 & 21 & 129.833 & 127 & 119 & 154 \\
\hline 140 & 16 & 112 & 134.640 & 131 & 0 & 153 \\
\hline 141 & 2 & 19 & 139.628 & 102 & 130 & 151 \\
\hline 142 & 1 & 13 & 144.832 & 115 & 83 & 146 \\
\hline 143 & 26 & 36 & 150.359 & 126 & 118 & 154 \\
\hline 144 & 10 & 66 & 158.918 & 107 & 121 & 149 \\
\hline 145 & 3 & 5 & 168.267 & 129 & 132 & 148 \\
\hline 146 & 1 & 22 & 177.959 & 142 & 112 & 152 \\
\hline 147 & 8 & 30 & 188.404 & 113 & 134 & 152 \\
\hline 148 & 3 & 17 & 198.866 & 145 & 120 & 157 \\
\hline 149 & 10 & 69 & 210.070 & 144 & 136 & 156 \\
\hline 150 & 7 & 11 & 221.403 & 135 & 123 & 155 \\
\hline 151 & 2 & 28 & 233.842 & 141 & 133 & 156 \\
\hline 152 & 1 & 8 & 254.973 & 146 & 147 & 159 \\
\hline 153 & 16 & 23 & 276.434 & 140 & 138 & 157 \\
\hline 154 & 6 & 26 & 298.056 & 139 & 143 & 158 \\
\hline 155 & 4 & 7 & 326.856 & 137 & 150 & 159 \\
\hline 156 & 2 & 10 & 358.982 & 151 & 149 & 158 \\
\hline 157 & 3 & 16 & 394.491 & 148 & 153 & 160 \\
\hline 158 & 2 & 6 & 449.656 & 156 & 154 & 160 \\
\hline 159 & 1 & 4 & 508.526 & 152 & 155 & 161 \\
\hline 160 & 2 & 3 & 623.275 & 158 & 157 & 161 \\
\hline 161 & 1 & 2 & 805.000 & 159 & 160 & 0 \\
\hline
\end{tabular}


Appendix 5: List of firms by cluster membership

\begin{tabular}{|c|c|}
\hline Company Name & Cluster Membership \\
\hline 1:AGILENT TECHNOLOGIES INC & 1 \\
\hline 8:APPLIED MATERIALS INC & 1 \\
\hline 9:ADVANCED MICRO DEVICES & 1 \\
\hline 13:BOEING CO & 1 \\
\hline 14:BAXTER INTERNATIONAL INC & 1 \\
\hline 18:BIOGEN IDEC INC & 1 \\
\hline 22:BOSTON SCIENTIFIC CORP & 1 \\
\hline 24:CATERPILLAR INC & 1 \\
\hline 30:CUMMINS INC & 1 \\
\hline 37:DEERE \& CO & 1 \\
\hline 44:EASTMAN KODAK CO & 1 \\
\hline 51:FORD MOTOR CO & 1 \\
\hline 63:HANESBRANDS INC & 1 \\
\hline 70:HARRIS CORP & 1 \\
\hline 74:INTEL CORP & 1 \\
\hline 78:JABIL CIRCUIT INC & 1 \\
\hline 90:LILLY (ELI) \& CO & 1 \\
\hline 92:MASCO CORP & 1 \\
\hline 101:MARVELL TECHNOLOGY GROUP LTD & 1 \\
\hline 102:MOTOROLA SOLUTIONS INC & 1 \\
\hline 113:NVIDIA CORP & 1 \\
\hline 124:PARKER-HANNIFIN CORP & 1 \\
\hline 128:QUALCOMM INC & 1 \\
\hline 131:ROCKWELL AUTOMATION & 1 \\
\hline 142:STANLEY BLACK \& DECKER INC & 1 \\
\hline 151:TEXAS INSTRUMENTS INC & 1 \\
\hline 158:WHIRLPOOL CORP & 1 \\
\hline 2:ALCOA INC & 2 \\
\hline 10:AMPHENOL CORP & 2 \\
\hline 19:BALL CORP & 2 \\
\hline 20:BEMIS CO INC & 2 \\
\hline 28:COLGATE-PALMOLIVE CO & 2 \\
\hline 29:CLOROX CO/DE & 2 \\
\hline 31:ROCKWELL COLLINS INC & 2 \\
\hline 33:CAMPBELL SOUP CO & 2 \\
\hline 39:DEAN FOODS CO & 2 \\
\hline 47:EASTMAN CHEMICAL CO & 2 \\
\hline
\end{tabular}




\begin{tabular}{|c|c|}
\hline 57:GENERAL MILLS INC & 2 \\
\hline 65:HEINZ (H J) CO & 2 \\
\hline 66:HARLEY-DAVIDSON INC & 2 \\
\hline 69:HORMEL FOODS CORP & 2 \\
\hline 71:HOSPIRA INC & 2 \\
\hline 72:HERSHEY CO & 2 \\
\hline 75:INTL PAPER CO & 2 \\
\hline 80:JUNIPER NETWORKS INC & 2 \\
\hline 81:JOY GLOBAL INC & 2 \\
\hline 82:KELLOGG CO & 2 \\
\hline 85:COCA-COLA CO & 2 \\
\hline 86:LEAR CORP & 2 \\
\hline 87:LEGGETT \& PLATT INC & 2 \\
\hline 88:LIFE TECHNOLOGIES CORP & 2 \\
\hline 91:LUBRIZOL CORP & 2 \\
\hline 95:MOHAWK INDUSTRIES INC & 2 \\
\hline 96:MEAD JOHNSON NUTRITION CO & 2 \\
\hline 104:MICRON TECHNOLOGY INC & 2 \\
\hline 115:OWENS CORNING & 2 \\
\hline 125:PHILIP MORRIS INTERNATIONAL & 2 \\
\hline 134:SMITHFIELD FOODS INC & 2 \\
\hline 135:SHERWIN-WILLIAMS CO & 2 \\
\hline 136:SMUCKER (JM) CO & 2 \\
\hline 137:SARA LEE CORP & 2 \\
\hline 138:SONOCO PRODUCTS CO & 2 \\
\hline 146:TIMKEN CO & 2 \\
\hline 149:TYSON FOODS INC -CL A & 2 \\
\hline 157:WESTERN DIGITAL CORP & 2 \\
\hline 159:WEYERHAEUSER CO & 2 \\
\hline 160:EXXON MOBIL CORP & 2 \\
\hline 162:ZIMMER HOLDINGS INC & 2 \\
\hline 3:APPLE INC & 3 \\
\hline 5:ARCHER-DANIELS-MIDLAND CO & 3 \\
\hline 17:BAKER HUGHES INC & 3 \\
\hline 25:COCA-COLA ENTERPRISES INC & 3 \\
\hline 32:CONOCOPHILLIPS & 3 \\
\hline 45:LAUDER (ESTEE) COS INC -CL A & 3 \\
\hline 46:EMC CORP/MA & 3 \\
\hline 55:GENZYME CORP & 3 \\
\hline 64:HESS CORP & 3 \\
\hline
\end{tabular}




\begin{tabular}{|c|c|}
\hline 100:MARATHON OIL CORP & 3 \\
\hline 111:NETAPP INC & 3 \\
\hline 130:REYNOLDS AMERICAN INC & 3 \\
\hline 141:SUNOCO INC & 3 \\
\hline 153:UNITED TECHNOLOGIES CORP & 3 \\
\hline 4:ABBOTT LABORATORIES & 4 \\
\hline 7:ALLERGAN INC & 4 \\
\hline 11:AVON PRODUCTS & 4 \\
\hline 12:AVERY DENNISON CORP & 4 \\
\hline 15:BECTON DICKINSON \& CO & 4 \\
\hline 34:CISCO SYSTEMS INC & 4 \\
\hline 38:DELL INC & 4 \\
\hline 42:DOW CHEMICAL & 4 \\
\hline 43:ECOLAB INC & 4 \\
\hline 48:EMERSON ELECTRIC CO & 4 \\
\hline 50:EATON CORP & 4 \\
\hline 61:GOODYEAR TIRE \& RUBBER CO & 4 \\
\hline 68:HEWLETT-PACKARD CO & 4 \\
\hline 79:JOHNSON \& JOHNSON & 4 \\
\hline 83:KRAFT FOODS INC & 4 \\
\hline 84:KIMBERLY-CLARK CORP & 4 \\
\hline 94:MEDTRONIC INC & 4 \\
\hline $97: 3 \mathrm{M} \mathrm{CO}$ & 4 \\
\hline 99:MERCK \& CO & 4 \\
\hline 109:NIKE INC & 4 \\
\hline 121:PEPSICO INC & 4 \\
\hline 122:PFIZER INC & 4 \\
\hline 123:PROCTER \& GAMBLE CO & 4 \\
\hline 127:PRAXAIR INC & 4 \\
\hline 161:XEROX CORP & 4 \\
\hline 6:AGCO CORP & 5 \\
\hline 21:BROADCOM CORP & 5 \\
\hline 26:CROWN HOLDINGS INC & 5 \\
\hline 27:CELGENE CORP & 5 \\
\hline 36:DANA HOLDING CORP & 5 \\
\hline 40:DANAHER CORP & 5 \\
\hline 41:DOVER CORP & 5 \\
\hline 49:ENERGIZER HOLDINGS INC & 5 \\
\hline 52:FLOWSERVE CORP & 5 \\
\hline 53:FORTUNE BRANDS INC & 5 \\
\hline
\end{tabular}




\begin{tabular}{|c|c|}
\hline 54:GENERAL DYNAMICS CORP & 5 \\
\hline 56:GILEAD SCIENCES INC & 5 \\
\hline 58:CORNING INC & 5 \\
\hline 59:GOODRICH CORP & 5 \\
\hline 60:GARMIN LTD & 5 \\
\hline 62:HASBRO INC & 5 \\
\hline 67:HONEYWELL INTERNATIONAL INC & 5 \\
\hline 73:HUNTSMAN CORP & 5 \\
\hline 76:ILLINOIS TOOL WORKS & 5 \\
\hline 77:JARDEN CORP & 5 \\
\hline 89:L-3 COMMUNICATIONS HLDGS INC & 5 \\
\hline 93:MATTEL INC & 5 \\
\hline 103:MANITOWOC CO & 5 \\
\hline 106:MYLAN INC & 5 \\
\hline 108:NCR CORP & 5 \\
\hline 110:NATIONAL OILWELL VARCO INC & 5 \\
\hline 114:NEWELL RUBBERMAID INC & 5 \\
\hline 116:OWENS-ILLINOIS INC & 5 \\
\hline 117:OSHKOSH CORP & 5 \\
\hline 118:PITNEY BOWES INC & 5 \\
\hline 119:PACCAR INC & 5 \\
\hline 120:PRECISION CASTPARTS CORP & 5 \\
\hline 126:PPG INDUSTRIES INC & 5 \\
\hline 132:DONNELLEY (R R) \& SONS CO & 5 \\
\hline 133:SEALED AIR CORP & 5 \\
\hline 139:SPX CORP & 5 \\
\hline 140:ST JUDE MEDICAL INC & 5 \\
\hline 143:STRYKER CORP & 5 \\
\hline 145:TEREX CORP & 5 \\
\hline 147:THERMO FISHER SCIENTIFIC INC & 5 \\
\hline 148:TRW AUTOMOTIVE HOLDINGS CORP & 5 \\
\hline 152:TEXTRON INC & 5 \\
\hline 154:VARIAN MEDICAL SYSTEMS INC & 5 \\
\hline 155:VF CORP & 5 \\
\hline 16:BECKMAN COULTER INC & 6 \\
\hline 23:CONAGRA FOODS INC & 6 \\
\hline 35:CHEVRON CORP & 6 \\
\hline 98:ALTRIA GROUP INC & 6 \\
\hline 105:MURPHY OIL CORP & 6 \\
\hline 107:NAVISTAR INTERNATIONAL CORP & 6 \\
\hline
\end{tabular}




\begin{tabular}{|l|c|}
\hline 112:NUCOR CORP & 6 \\
\hline 129:RALCORP HOLDINGS INC & 6 \\
\hline 144:MOLSON COORS BREWING CO & 6 \\
\hline 150:TESORO CORP & 6 \\
\hline 156:VALERO ENERGY CORP & 6 \\
\hline Case & 6 Clusters \\
\hline
\end{tabular}


VITA

\section{DINA ABDEL-ZAHER}

Doctor of Philosophy Candidate, Management \& International Business (2008-August 2012. Florida International University, Miami, FL.

Dissertation Topic: Corporate's Environmental Management Framework: The Complexities Of Subsidiary Network Dimensions

Committee Members:

Dr.William Newburry (FIU-Chair); Dr. Jose de la Torre (FIU); Dr. Nathan Hiller (FIU) Dr. William Schneper (FIU); Dr Walfried Lassar (FIU-Marketing); Dr. Ted London (University of Michigan)

\section{RESEARCH AWARDS}

Kauffman Doctoral Assistant Award 2011 awarded a research grant of $\$ 7000$ from Global Entrepreneurship Center at Florida International University for research studying the relationships between global mindsets, entrepreneurship orientation, and individual Innovation.

Runner Up Paper Award at Academy of International Business Southwest 2011 Abdelzaher, D., Newburry, W., \& Kundu, S. "How Offshoring Affects Corporate Reputation at Home:Examining its dual impact on Firm Performance and Corporate Social Responsibility", March 9-12 in Houston, Texas.

William J. Ziegler Award (Best Student Paper) at the Academy of International Business Southeast 2009. Abdelzaher, D. \& Schneper, W. "The Diffusion of Corporate Social Responsibility: A Cross Country Empirical study". October in Jacksonville, F1.

\section{RESEARCH PUBLICATIONS}

Abdelzaher, D. “The Impact of Professional Service Firms' Expansion Challenges on Internationalization Processes and Performance”. The Service Industries Journal. Forthcoming 2012. Impact Factor 1.071.

Schotter, A. \& Abdelzaher, D. "The Effects of Muslim Diaspora on the Internationalization Processes of Firms from Organization of Islamic Conference 
Countries". Conditionally Accepted Journal of International Management. Impact Factor 1.298.

Abdelzaher, D., Newburry, W., \& Kundu, S. 2011 "How Offshoring Affects Corporate Reputation at Home: Examining its dual impact on Firm Performance and Corporate Social Responsibility" Southwest Review of International Business Research vol 22, (1): 135.

Abdelzaher, D. \& De la Torre, J.2011 “A Framework of the MNC's Optimal Configuration: An Examination of the Joined Effect of Dispersion, Density, and Diversity”. Southwest Review of International Business Research vol 22, (1): 27.

\section{CONFERENCE PROCEEDINGS}

Abdelzaher, D. \& Schneper, W. "The Diffusion of Corporate Social Responsibility: A Cross Country Empirical study", Academy of Management 2010, August 6-10 in Montreal, Canada. Earlier version published in the conference proceedings at Academ of International Business- Southeast 2009 (CD). Targeted Journal of Internationa of Business Studies.

Bullough, A., Renko, M., \& Abdelzaher, D. “Women's Entrepreneurship: Operating Within the Context of Institutional and In-Group Collectivism", published in the conference proceedings Academy of International Business Southeast 2011, October 24 in Orlando.

Bullough, A. \& Abdelzaher, D. "An Overview of Available Data Sources \& Limitations In Global Research On Women's Entrepreneurship", published in the conference proceedings Academy of International Business Southeast 2011, October 24 in Orlando. 